UNIVERSIDADE DE BRASÍLIA

FACULDADE DE ECONOMIA, ADMINISTRAÇÃO E CONTABILIDADE DEPARTAMENTO DE ECONOMIA MESTRADO EM ECONOMIA DO SETOR PÚBLICO

ELY ARIMA TAKASAKI

\title{
O NOVO MODELO BRASILEIRO DE EXPLORAÇÃO FERROVIÁRIA
}




\section{O NOVO MODELO BRASILEIRO DE EXPLORAÇÃO FERROVIÁRIA}

Dissertação apresentada ao Departamento de Economia da Universidade Brasília, como requisito parcial para a obtenção do título de Mestre em Economia do Setor Público.

ORIENTADOR: Prof. Dr. César Costa Alves de Mattos

Brasília

2014 


\section{RESUMO}

O presente trabalho estuda o novo modelo de exploração ferroviária a ser implementado no Brasil, que tem como principais características a separação vertical ("unbundling”) entre a gestão da infraestrutura e a prestação do serviço de transporte e o regime de "open access", a partir de pesquisa na literatura e experiência internacionais, com foco no transporte de cargas. A competitividade do Brasil é prejudicada pelos elevados custos logísticos e uma das apostas do governo brasileiro para contornar este problema envolve a expansão da malha ferroviária, em sua maior parte, por meio de concessões ao setor privado, e o estabelecimento de competição intramodal. Diferentemente das concessões outorgadas até o momento, verticalmente integradas, as novas concessões envolverão a construção (na maior parte dos casos) e gestão da infraestrutura, enquanto o serviço de transporte será realizado por múltiplos operadores, em um ambiente concorrencial. Neste contexto, apenas a infraestrutura continuará com tratamento de monopólio natural. Conforme se poderá verificar, o modelo brasileiro acompanha tendência observada em diversas partes do mundo, com destaque para países da União Europeia e a Austrália, com separação vertical do tipo organizacional. Em estudos com enfoque nessas experiências, foram encontradas evidências de que os benefícios superam os custos, notando-se como as principais fragilidades associadas, os problemas de coordenação e o desalinhamento de incentivos. Ao final, conclui-se que a separação vertical com "open access" poderia ser benéfica para o caso brasileiro.

Palavras-chaves: Economia do setor público. Ferrovias. Concessões Ferroviárias. Separação Vertical. Open Access. 


\begin{abstract}
This document studies the new model of railway exploitation to be implemented in Brazil, which has as its main features the vertical separation (unbundling) between infrastructure management and the provision of transport services, and open access, based on international references and experiences, with focus on freight operations. The competitiveness of Brazil is hampered by high logistics costs and one of the bets of the Brazilian government to overpass this problem comprises the expansion of the railway network, mostly through concessions to the private sector, and the establishment of intramodal competition. Unlike the concessions granted to date, vertically integrated, the new concessions will comprise the construction (in most cases) and management of infrastructure, while the transport services will be performed by multiple operators in a competitive environment. In this context, only the infrastructure will continue with a treatment of natural monopoly. As it will be presented, the Brazilian model follows the trend observed in various parts of the world, especially in European Union countries and Australia, with organizational separation ('holding company model'). In studies focusing on these experiences, evidences that the benefits outweigh the costs were found, noting as the main weaknesses associated, coordination problems and misalignment of incentives. Thus, it is concluded that the vertical separation with "open access" could be benefic for the Brazilian case.
\end{abstract}

Keywords: Economics of the public sector. Railways. Rail Concessions. Unbundling. Open Access. 


\section{ÍNDICE}

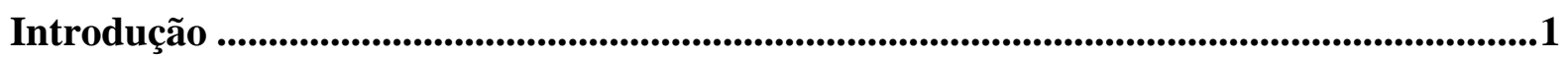

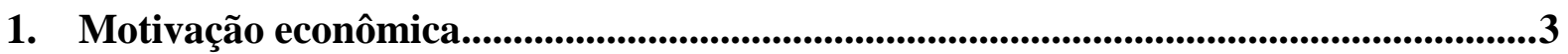

1.1. Dependência brasileira da exportação de matérias-primas ......................................... 7

1.2. Volume exportado $x$ Preço de commodities selecionadas .......................................... 9

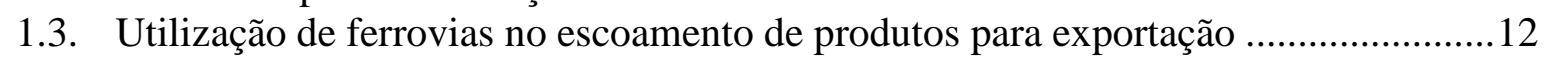

1.4. Comprometimento da competitividade das commodities agrícolas brasileiras ..........14

2. Regulação da infraestrutura e organização do setor ferroviário ...............................17

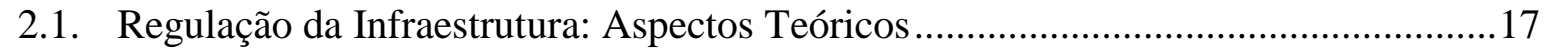

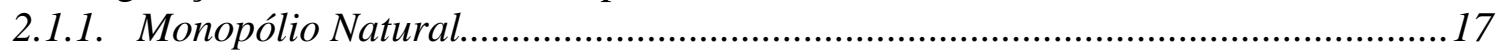

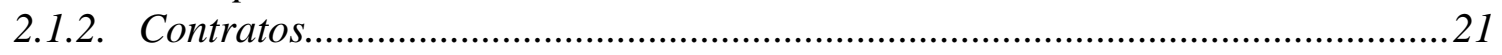

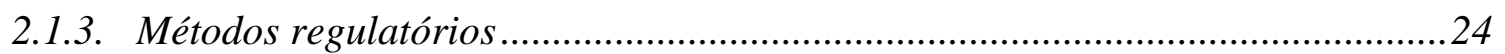

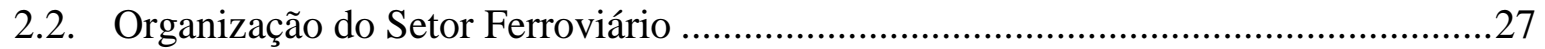

2.2.1. Modelo vertical de exploração de serviços ferroviários ......................................2. 28

2.2.2. Separação vertical da exploração de serviços ferroviários ................................... 31

3. Ferrovias e concessões ferroviárias no Brasil...................................................................41

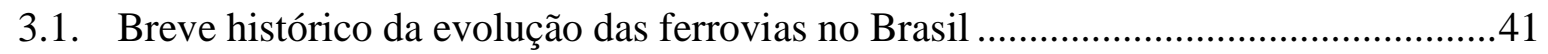

3.2. A experiência brasileira em concessões ferroviárias ...................................................4

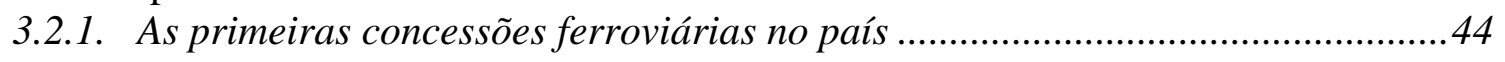

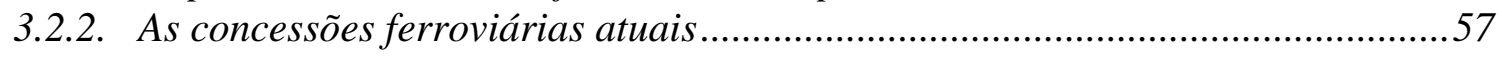

3.2.3. Efeitos das concessões das malhas da antiga RFFSA .........................................64

3.2.4. O modelo de concessão das malhas da antiga RFFSA......................................85

4. O novo modelo brasileiro de exploração ferroviária .................................................96

4.1. Separação vertical com "open access" no Brasil......................................................96

4.2. Modelagem das novas concessões ferroviárias ......................................................... 103

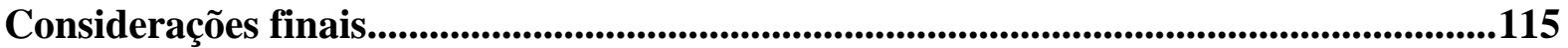

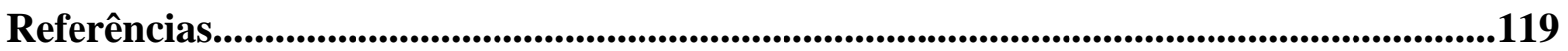




\section{LISTA DE FIGURAS}

Figura 1 - Brasil: Preço médio de exportação (US\$/t) - Minério de ferro, Soja, Milho - 2002 a

2013.

Figura 2 - Brasil: Preço médio por tonelada exportada (US\$/t) x Volume total exportado (milhões de toneladas) - minério de ferro - 2002 a 2013

Figura 3 - Brasil: Preço médio por tonelada exportada (US\$/t) x Volume total exportado (milhões de toneladas) - Soja e Farelo de Soja - 2002 a 2013

Figura 4 - Preço médio por tonelada exportada (US\$/t) x Volume total exportado (milhões de toneladas) - Milho - 2002 a 2013

Figura 5 - Volume exportado, Volume transportado por ferrovia, Volume transportado por ferrovia sobre o total exportado (\%) - Celulose, Açúcar, Milho, Soja e Farelo de Soja,

Minério de Ferro - 2013

Figura 6 - Esquema teórico: formação de preço de uma empresa monopolista......................20

Figura 7 - Ferrovias da antiga RFFSA: Índice da evolução da produção de transporte, total e por concessionária, 2001 a 2013; Índice da evolução do volume exportado pelo Brasil de minério de ferro - Ano-base: $1994 .$.

Figura 8 - Ferrovias da antiga RFFSA: Número de acidentes / milhão de trem.km, média e por concessionária - 2003 a 2013

Figura 9 - Participação, em TKU, das principais mercadorias transportadas pelas ferrovias da antiga RFFSA (\%) - 1994 e 2013

Figura 10 - Ferrovias da antiga RFFSA: Índice da evolução do número de clientes, total e por concessionária - 2002 a 2011 - Ano-base: 2002

Figura 11 - Ilustração referente às tarifas envolvidas no tráfego pelas malhas concedidas no marco do novo modelo de concessão ferroviária. 


\section{LISTA DE TABELAS}

Tabela 1 - Brasil: Matriz de Transportes (TKU), com e sem minério de ferro - 2011 .4

Tabela 2 - Transporte Ferroviário: participação em TKU por mercadoria (\%), comparativo Brasil (2012) e Austrália (2011/2012)

Tabela 3 - Organização funcional do setor ferroviário (Exploração da infraestrutura e prestação do serviço de transporte)

Tabela 4 - Exemplos de países que adotaram a separação vertical no setor ferroviário, por tipo

Tabela 5 - Grupo I - Concessões das malhas da antiga RFFSA - 2013 (extensão total: 24.671

$\mathrm{km})$

Tabela 6 - Grupo II - Demais ferrovias em operação no Brasil - 2013 (extensão total: 3.815,4

$\mathrm{km})$

Tabela 7 - Ferrovias da antiga RFFSA: Produção de transporte (milhões de TKU), por concessionária - 1994, 2002 (estimado e realizado), 2013

Tabela 8 - Ferrovias da antiga RFFSA: Produção de Transporte - Realizado / Meta (\%), por concessionária - 2003 a 2011

Tabela 9 - Ferrovias da antiga RFFSA: Produção de Transporte - Atendimento de metas por trecho, por concessionária - 2012 e 2013.

Tabela 10 - Ferrovias da antiga RFFSA: (Número de acidentes / milhão de trem.km) / Meta

de Segurança (\%), por Concessionária - 2003 a 2011

Tabela 11 - Ferrovias da antiga RFFSA: Produtividade por quilometragem (TKU/km) e

Produtividade por empregado (TKU/empregado), por concessionária - 1994, 2013;

Velocidade média de percurso $(\mathrm{km} / \mathrm{h})$, por concessionária - 2013; Distância Média de

Viagem $(\mathrm{km})$, por concessionária - 2013

Tabela 12 - Ferrovias da antiga RFFSA: Investimento total, por área de aplicação (R\$ milhões, valores correntes) - 2006 a 2013

Tabela 13 - Ferrovias da antiga RFFSA: Material Rodante em circulação, total e por concessionária - Pré-concessão e 2013

Tabela 14 - Ferrovias da antiga RFFSA: Produção em Tráfego Mútuo (TM) e Direito de Passagem (DP), em bilhões de TKU, por malha receptora - 2004 a 2008 



\section{INTRODUÇÃO}

Tendo em vista os elevados custos logísticos que prejudicam a competitividade brasileira, acredita-se que haja potencial para aumento da participação do modal ferroviário na matriz de transportes do país. Contudo, para que isso seja possível, há alguns requisitos que necessitam ser previamente cumpridos, dentre os quais se destacam: expansão da malha ferroviária - construção de novas ferrovias e ampliação de capacidade em trechos existentes (construção de pátios, estações, oficinas, retificações de traçados, sistemas de sinalização, telecomunicações, gerenciamento, controle, etc.); disponibilidade de fretes competitivos e qualidade na prestação dos serviços.

Conforme estratégia do governo brasileiro, os investimentos na expansão da malha ferroviária serão realizados, em sua maior parte, por meio de concessão privada. Neste contexto, as novas concessões serão outorgadas no marco de um novo modelo de exploração ferroviária, em que o concessionário será responsável pela construção e gestão da infraestrutura, enquanto o serviço de transporte ficará a cargo de operadores de transporte "sem trilhos", em um esquema de separação vertical. Ao mesmo tempo, os operadores terão o direito de trafegar ao longo das diversas malhas, em regime de "open access", favorecendo a organização de um ambiente concorrencial.

Para que este modelo seja exitoso, no entanto, será decisivo o papel do governo no estímulo ao estabelecimento de um ambiente regulatório adequado à atração dos investimentos privados requeridos e à promoção da eficiência setorial e do bem-estar dos usuários.

Neste contexto, este trabalho estuda o novo modelo de exploração ferroviária a ser implementado no país, com foco específico no transporte de cargas, com o objetivo de entender a racionalidade presente, sob o ponto de vista econômico, nas mudanças que estão sendo promovidas pelo governo e realizar uma análise crítica, com base na experiência e 
literatura internacionais. Em termos metodológicos, o trabalho foi desenvolvido por meio de investigação bibliográfica documental, resultando em uma pesquisa descritiva e explicativa.

A estrutura do trabalho compreende quatro capítulos, além da introdução e considerações finais. No primeiro capítulo são apresentadas motivações econômicas para o investimento em ferrovias no Brasil, trazendo elementos que estão associados ao assim denominado "custo Brasil". O capítulo seguinte contém aspectos teóricos relacionados à regulação da infraestrutura, bem como a descrição das diferentes formas de organização do setor ferroviário, incluindo contribuições obtidas a partir de pesquisa a trabalhos que examinam a experiência internacional. O terceiro capítulo, por sua vez, tem como foco a análise da experiência brasileira em concessões de ferrovias e está dividido em duas partes. A primeira trata das concessões promovidas pelo governo imperial, enquanto a segunda parte explora as concessões vigentes (verticalmente integradas), em sua maior parte outorgadas no contexto do primeiro ciclo de reformas promovidas no setor, que resultou no fim da Rede Ferroviária Federal S.A. (RFFSA). Por fim, o último capítulo apresenta e analisa o novo modelo brasileiro de exploração ferroviária, em regime de separação vertical e "open access", a ser implementado no marco de um novo ciclo de reformas em desenvolvimento no setor ferroviário. 


\section{MOTIVAÇÃO ECONÔMICA}

É reconhecida a importância da disponibilidade de uma rede de transporte eficiente para a competitividade de um país. Quando o custo de transporte representa uma parcela relevante do preço do produto exportado em função, por exemplo, de seu baixo valor agregado, o impacto desta infraestrutura na competitividade é ainda maior. Sendo o Brasil, desde sua formação, caracterizado pela forte dependência da exportação de matérias-primas, o efeito da precária infraestrutura de transportes é relativamente mais significativo.

De fato, é consenso que a matriz de transportes brasileira não favorece a competitividade do país. Conforme dados do Ministério dos Transportes referentes a 2011, $52 \%$ da carga foi transportada pelo modal rodoviário, 30\% pelo modal ferroviário, $5 \%$ pelo modal hidroviário e o restante pelos demais modais. Essa distribuição é desfavorável, sobretudo, quando se leva em consideração a natureza ${ }^{1}$ das cargas transportadas e as elevadas distâncias percorridas. ${ }^{2}$

O referido desequilíbrio se coloca ainda mais evidente quando o minério de ferro é excluído da análise. Conforme se observa na Tabela 1 - que compara a divisão modal do transporte de mercadorias no Brasil em 2011 nas situações com e sem o minério de ferro, ao se excluir o minério de ferro dos cálculos, a participação do modal rodoviário salta de $52 \%$ para $68 \%$, enquanto o modal ferroviário perde 20 p.p. de participação, de $30 \%$ para $10 \%$.

\footnotetext{
${ }^{1}$ Refere-se ao baixo valor agregado e elevados volumes das mercadorias.

${ }^{2}$ Cf. ESTACHE, GOLDSTEIN e PITTMAN (2001, p.4)
} 
Tabela 1 - Brasil: Matriz de Transportes (TKU), com e sem minério de ferro - 2011

Participação na Matriz de Transportes (\%)

\begin{tabular}{lcc}
\hline Modal & Com minério de ferro & Sem minério \\
Rodoviário & $52 \%$ & $68 \%$ \\
Ferroviário & $30 \%$ & $10 \%$ \\
Hidroviário & $5 \%$ & $6 \%$ \\
Demais & $13 \%$ & $16 \%$
\end{tabular}

Fonte: PNLT/MT (2012)

Esta condição revela a necessidade de fortalecimento no país de modais alternativos ao rodoviário. Neste contexto, este trabalho trata especificamente do transporte ferroviário de cargas. Do total de 294,9 bilhões de TKU (toneladas por quilômetro útil ${ }^{3}$ ) de mercadorias transportadas em 2012 pelas ferrovias brasileiras, o minério de ferro ${ }^{4}$ representou $73,5 \%{ }^{5}$.

Adicionalmente ao minério de ferro, os principais grupos de produtos transportados pelas ferrovias brasileiras em 2012 foram: produtos agrícolas (14,6\%, dos quais 7,0\% corresponderam à soja e farelo de soja); produtos siderúrgicos (2,8\%); combustíveis, derivados de petróleo e álcool (2,2\%); e minerais $(1,8 \%)$. Por outro lado, a participação da carga geral (conteinerizada e não-conteinerizada ${ }^{6}$ ) no mesmo ano se limitou a $0,6 \%$. Por apresentar dimensões continentais e dotações naturais similares aos do Brasil, vale uma

\footnotetext{
${ }^{3}$ TKU: Medida de desempenho operacional de uma ferrovia que estabelece a produção, baseada na multiplicação da tonelagem transportada (sem incluir o peso das locomotivas e vagões) pela distância percorrida pela composição (DE SOUSA e PRATES, 1997).

${ }^{4}$ A história das ferrovias, desde a sua origem, sempre esteve associada à exploração mineral. Em 1804, Trevithick fez uma experiência com este veículo, puxando um vagão carregado com 9 toneladas de carvão, por uma via de trilhos com $15 \mathrm{~km}$ de extensão. Assim nascia a primeira locomotiva. (NATIONAL MUSEUM WALES, 2014)

${ }^{5}$ Cf. ANTT (2014e)

${ }^{6}$ Exemplos: Produtos petroquímicos, veículos, máquinas, motores, peças e acessórios.
} 
comparação com o caso australiano - constante na Tabela 2. No ano 2011/2012, as ferrovias da Austrália responderam por uma produção bastante próxima da alcançada pelas estradas de ferro brasileiras - 290,57 bilhões de TKU, com destaque para os grupos de produtos que tradicionalmente utilizam este modal: minério de ferro $(60,4 \%)$, carvão $(21,4 \%)$, grãos $(2,4 \%)$, produtos siderúrgicos $(1,5 \%)$ e minerais $(0,4 \%)$. Nota-se, no entanto, que diferentemente do perfil da carga transportada pelas linhas férreas brasileiras, a carga geral ${ }^{7}$ (conteinerizada e não-conteinerizada) tem uma participação relevante na Austrália, sendo que, no período considerado, representou $10,7 \%^{8}$ do total transportado pelo modal naquele país. A partir deste comparativo, sugere-se que, apesar de o modal ferroviário apresentar vocação natural para o transporte de cargas de baixo valor agregado e grande volume, com fluxos concentrados e por grandes distâncias, haveria mercado potencial no Brasil para a ampliação da participação das ferrovias no transporte de carga geral.

\footnotetext{
${ }^{7}$ É importante mencionar que a carga geral, normalmente, exige a utilização de modal de transporte complementar ao ferroviário. Neste sentido, a ampliação da utilização das ferrovias no transporte de carga geral depende de ações complementares como, por exemplo, a instalação de terminais multimodais de carga, entre outros. 
Tabela 2 - Transporte Ferroviário: participação em TKU por mercadoria (\%), comparativo Brasil (2012) e Austrália (2011/2012)

$$
\text { Participação (\%) }
$$

\begin{tabular}{lcr}
\hline Produto & Brasil & Austrália \\
Minério de ferro & $73,5 \%$ & $60,4 \%$ \\
Carvão & $1,2 \%$ & $21,4 \%$ \\
Soja (grão e farelo) & $7,0 \%$ & \\
Outros produtos agrícolas & $7,6 \%$ & $2,4 \% *$ \\
Produtos siderúrgicos & $2,8 \%$ & $1,5 \%$ \\
Produtos minerais & $1,8 \%$ & $0,4 \%$ \\
$\begin{array}{l}\text { Carga geral (conteinerizada e } \\
\text { conteinerizada) }\end{array}$ & $\mathbf{0 , 6 \%}$ & $\mathbf{1 0 , 7 \%}$ \\
Demais & & $3,2 \%$
\end{tabular}

Fonte: ANTT (2014b) e ARA (2013)

Obs.: * Na Austrália, não são divulgados dados desagregados entre soja e outros produtos agrícolas.

Além da carga geral, identificam-se as commodities agrícolas, com destaque para aquelas destinadas à exportação, como detentoras de grande potencial de ampliação na utilização do transporte ferroviário. Para justificar esta afirmação, verifica-se, por exemplo, que em 2013 o Brasil exportou 42,8 milhões de toneladas de soja, ao passo que as ferrovias brasileiras transportaram apenas 16,1 milhões de toneladas da oleaginosa, equivalente a $35,6 \%$ do total exportado. ${ }^{9}$ Para efeito de comparação, cabe citar os Estados Unidos que praticamente não utilizam o modo rodoviário para o escoamento de soja até seus portos de embarque. De fato, em 2010, as vendas internacionais norte-americanas de soja alcançaram

\footnotetext{
${ }^{9}$ Conforme dados da CONAB (2014), a produção brasileira de soja na safra 2012/13 foi de 81,5 milhões de toneladas.
} 
46,2 milhões de toneladas, com $44 \%$ deste total sendo transportado por ferrovia e $47 \%$ por hidrovia. $^{10}$

\subsection{DEPENDÊNCIA BRASILEIRA DA EXPORTAÇÃO DE MATÉRIAS-PRIMAS}

A balança comercial brasileira é fortemente dependente da exportação de bens não manufaturados, especialmente de origem mineral e agropecuária. Do valor total de US\$ 242,2 bilhões em exportações de bens registrado em 2013, os produtos básicos e os semimanufaturados representaram juntos $59,3 \%$ (respectivamente, $46,7 \%$ e $12,6 \%$ ). Entre os produtos não manufaturados com maior participação nas exportações em 2013, destacaramse: minérios (16,8\%, sendo 13,4\% apenas de minério de ferro), soja e farelo de soja (11,9\%), carnes $(6,7 \%)$, petróleo bruto $(5,3 \%)$, açúcar em bruto $(3,8 \%)$, milho $(2,6 \%)$ e celulose $(2,1 \%)$

De fato, nos últimos anos o setor mineral ampliou sua importância na economia brasileira, aprofundando sua relevância na geração de divisas. Conforme dados do Ministério de Desenvolvimento, Indústria e Comércio Exterior, o setor registrou em 2013, superávit comercial no valor de US\$32,1 bilhões, com um volume de exportações bruto de US\$ 40,8 bilhões. No período compreendido entre 2009 e 2013, os minerais foram responsáveis, em média, por 16,2\% das exportações brasileiras, sendo este percentual o dobro da participação média observada no período 2002-2008 (8,1\%). Da pauta exportadora mineral, cabe destacar o minério de ferro, produto responsável por $77,3 \%$ do valor total de vendas externas registrado pelo setor na média do período 2002-2013.

Além dos minerais, os produtos agrícolas também incrementaram sua participação nas exportações nacionais nos últimos anos, ainda que em menor proporção. Deste grupo

\footnotetext{
${ }^{10}$ Cf. USDA (2013). No caso norte-americano, cumpre destacar a importância do rio Mississipi como importante via para o escoamento de mercadorias.
} 
ressalta-se o complexo soja (grãos, farelo e óleo) e o milho, que juntos responderam por 15,4\% do valor total em exportações de 2013. Verifica-se que de 2009 a 2013, a participação agregada destes produtos totalizou, em média, 12,1\% das vendas internacionais, correspondente a um aumento de $27,9 \%$ na comparação com a média observada no período $2002-2008(9,5 \%)$.

Um dos fatores que mais favoreceram os bons resultados acima assinalados foi o fenômeno denominado "boom das commodities", impulsionado pelo crescimento da economia asiática, especialmente da China. Conforme ilustrado na Figura 1, a tonelada do minério de ferro que era exportada pelo Brasil a um preço médio de US\$ 19,77/t em 2003, foi negociada a um valor médio de US\$ 58,71/t em 2008, alcançando US\$ 98,57/t em 2013 com recorde histórico de US\$126,40/t observado em 2011. Da mesma forma, a soja, que era exportada em 2003 a um preço médio de US\$ 215,70/t, em 2008 alcançou o valor de US\$ 447,04/t e em 2013, US\$ 533,05/t. Além do minério de ferro e da soja, o milho também apresentou forte elevação no preço médio de exportação; vendido em 2003 a um preço médio de US\$ 105,20/t, em 2013 foi negociado a um valor médio de US\$ 236,91/t (equivalente a um aumento de $125,2 \%)$. 
Figura 1 - Brasil: Preço médio de exportação (US\$/t) - Minério de ferro, Soja, Milho - 2002 a 2013

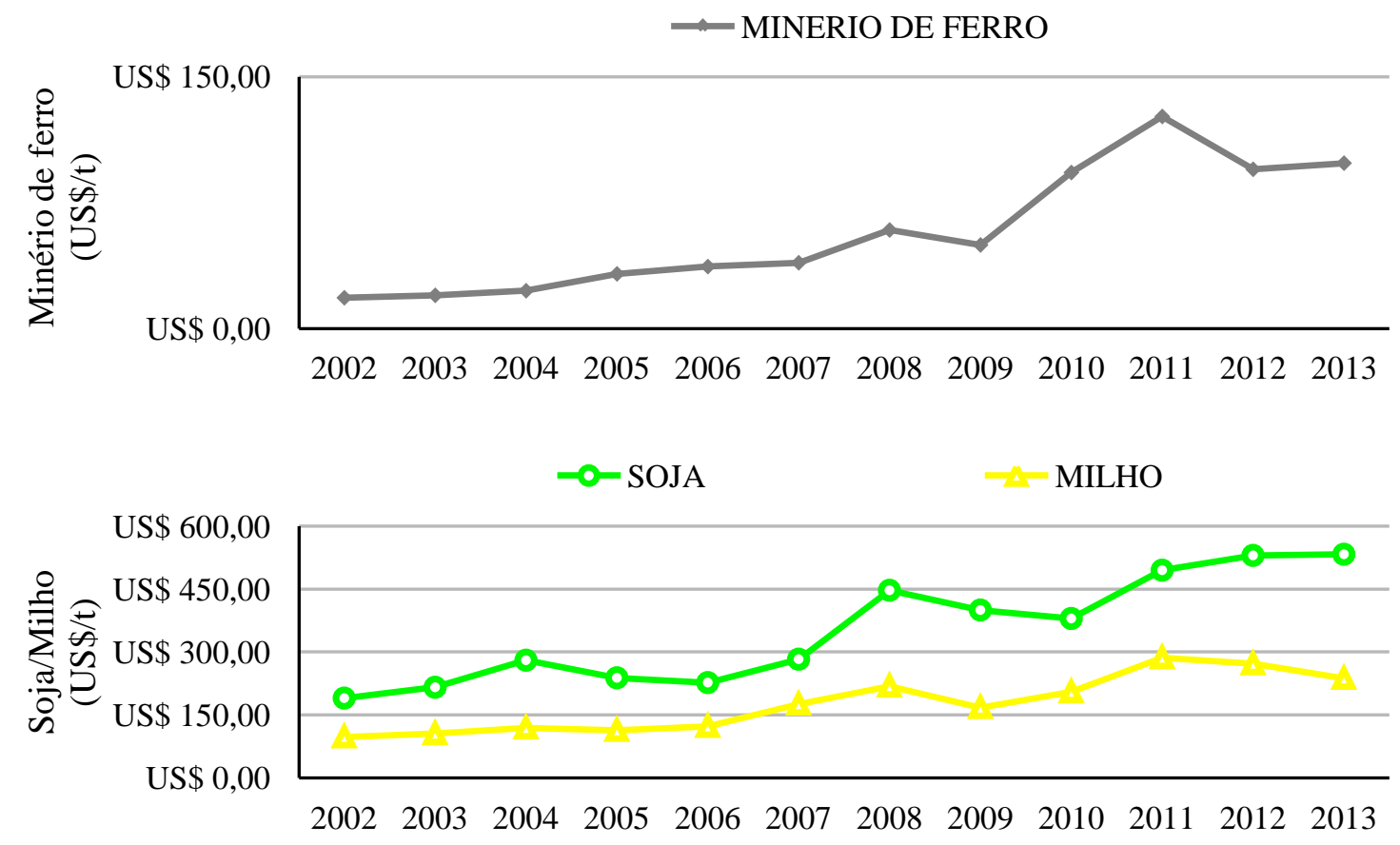

Fonte: Aliceweb/MDIC (2014)

\subsection{VOLUME EXPORTADO X PREÇO DE COMMODITIES SELECIONADAS}

Conforme mencionado, no período 2002-2013, o preço médio de exportação do minério de ferro brasileiro mais que quadruplicou, com aumento de 438,4\% e elevação anual média de 20,2\%. No entanto, conforme se observa na Figura 2, o incremento no volume total exportado foi significativamente inferior à expansão nos preços, com ampliação de 97,9\% na comparação do total exportado em 2013 (329,6 milhões de toneladas) com o volume exportado em 2002 (166,5 milhões de toneladas). 
Figura 2 - Brasil: Preço médio por tonelada exportada (US\$/t) x Volume total exportado (milhões de toneladas) - minério de ferro - 2002 a 2013

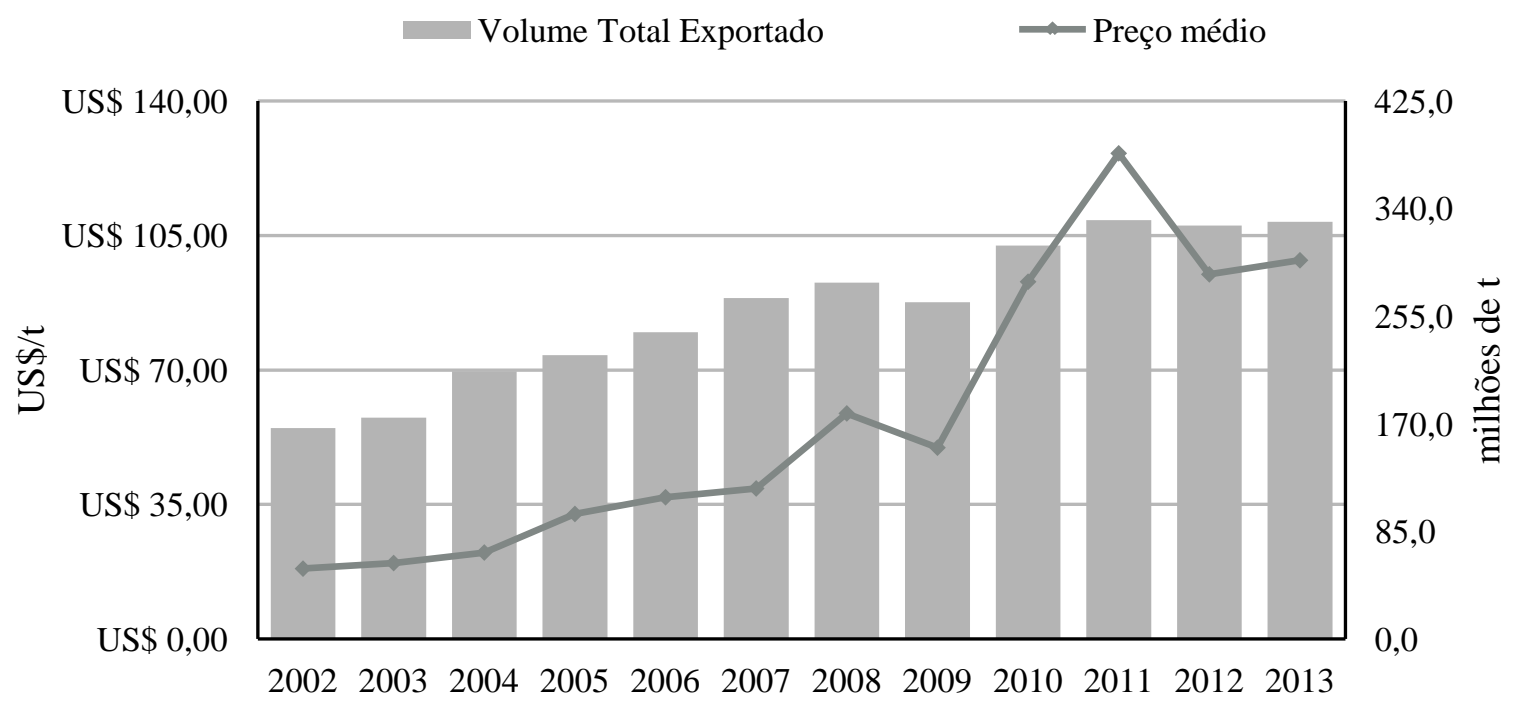

Fonte: Aliceweb/MDIC (2014)

A Figura 3 ilustra as variações dos preços médios e do volume total agregado de soja (em grãos e farelo) exportado pelo Brasil no período 2002-2013. Como se pode verificar, o preço médio apresentou crescimento de $187,2 \%$ na comparação 2002/2013, com elevação anual média de 11,6\%. Em volume, houve expansão de 97,0\% entre 2002 e 2013, totalizando 56,1 milhões de toneladas de soja e farelo de soja exportados no último ano da série histórica. 
Figura 3 - Brasil: Preço médio por tonelada exportada (US\$/t) x Volume total exportado (milhões de toneladas) - Soja e Farelo de Soja - 2002 a 2013

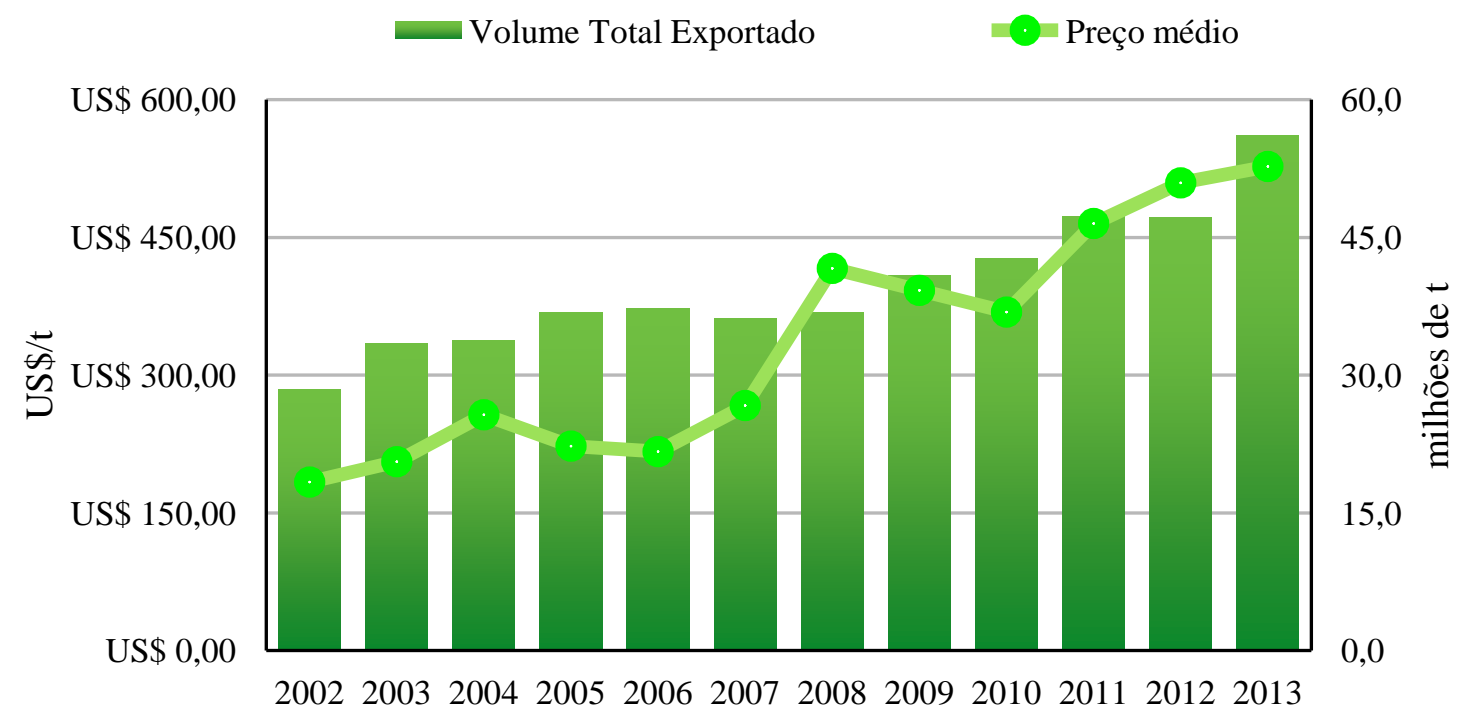

Fonte: Aliceweb/MDIC (2014)

No caso do milho, conforme se observa na Figura 4, o incremento no volume total exportado no período 2002-2013 foi significativamente superior à expansão nos preços, com ampliação de 869,2\% na comparação do total exportado em 2013 (29,6 milhões de toneladas) com o volume exportado em 2002 (2,7 milhões de toneladas), enquanto os preços médios apresentaram avanço de 143,2\% entre 2002/2013. Cabe assinalar que os volumes de milho exportados pelo Brasil em 2012 e 2013 foram atípicos e resultaram de quebra de safra nos Estados Unidos, maior produtor mundial do cereal. Conforme afirma a Associação Brasileira dos Produtores de Milho (Abramilho), o milho nacional tem baixa competitividade frente ao produto norte-americano nos mercados internacionais devido, entre outras razões, à deficiência logística. ${ }^{11}$

\footnotetext{
${ }^{11}$ Cf. ABRAMILHO (2014)
} 
Figura 4 - Brasil: Preço médio por tonelada exportada (US\$/t) x Volume total exportado (milhões de toneladas) - Milho - 2002 a 2013

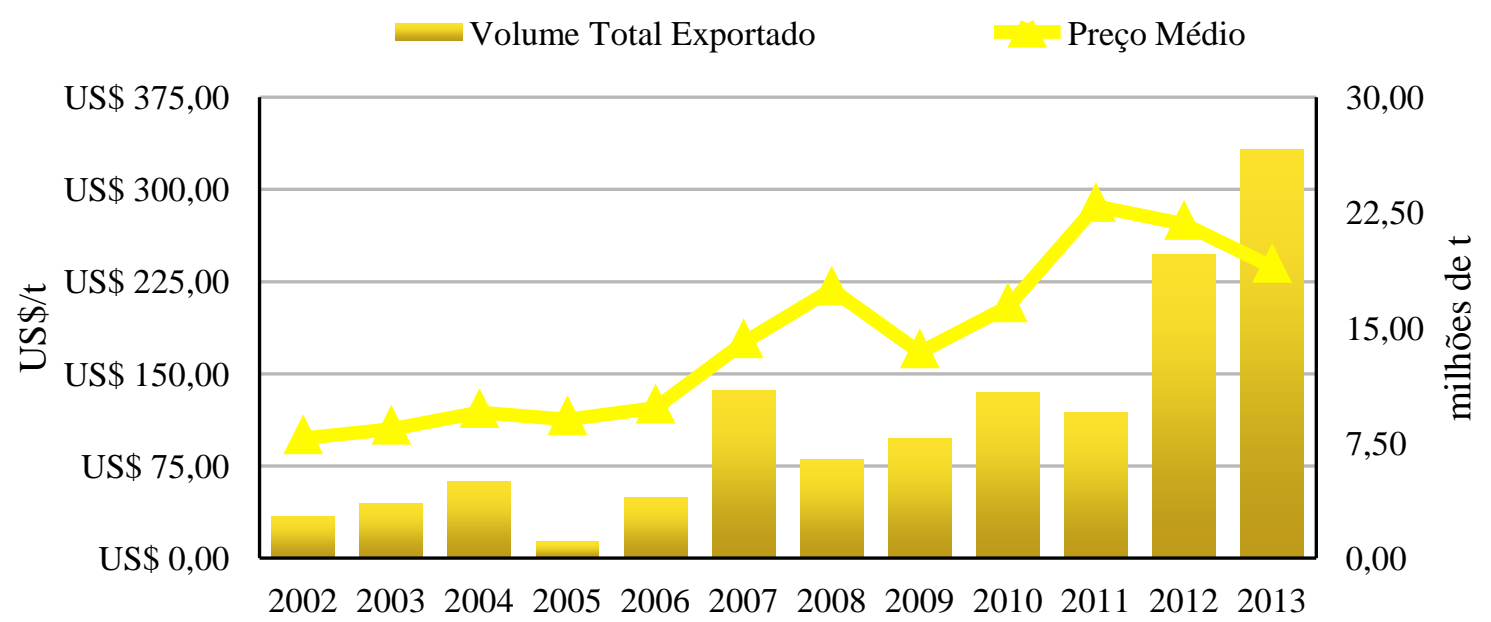

Fonte: Aliceweb/MDIC (2014)

\subsection{UTILIZAÇÃo DE FERROVIAS NO ESCOAMENTO DE PRODUTOS PARA EXPORTAÇÃO}

A Figura 5 apresenta um comparativo, referente ao ano de 2013, entre o volume total exportado e o volume transportado por ferrovia, para alguns dos principais produtos que compõem a pauta exportadora brasileira: minério de ferro, soja (em grãos e farelo), açúcar ${ }^{12}$, milho e celulose ${ }^{13}$.

Conforme se observa, para três destes produtos (celulose, soja em grão e farelo, açúcar), o volume transportado por ferrovia em 2013 correspondeu a menos de $40 \%$ do total exportado no mesmo ano. No caso do milho, esse percentual foi equivalente a um pouco mais da metade do volume total exportado $(52,3 \%)$. Por outro lado, nota-se que o volume total de

\footnotetext{
${ }^{12}$ Volume de açúcar exportado em 2013, cf. UNICA (2014)

${ }^{13}$ Volume de celulose exportado em 2013, cf. BRACELPA (2014)
} 
minério de ferro escoado por ferrovia foi superior ao volume de vendas internacionais do produto no mesmo ano. A partir destes números, tem-se que enquanto o modal ferroviário é intensivamente utilizado para o escoamento do minério de ferro ${ }^{14}$, a mesma condição não se verifica no transporte de outras mercadorias, sendo este o caso das commodities de origem vegetal.

Figura 5 - Brasil: Volume exportado, Volume transportado por ferrovia, Volume transportado por ferrovia sobre o total exportado (\%) - Celulose, Açúcar, Milho, Soja e Farelo de Soja, Minério de Ferro - 2013

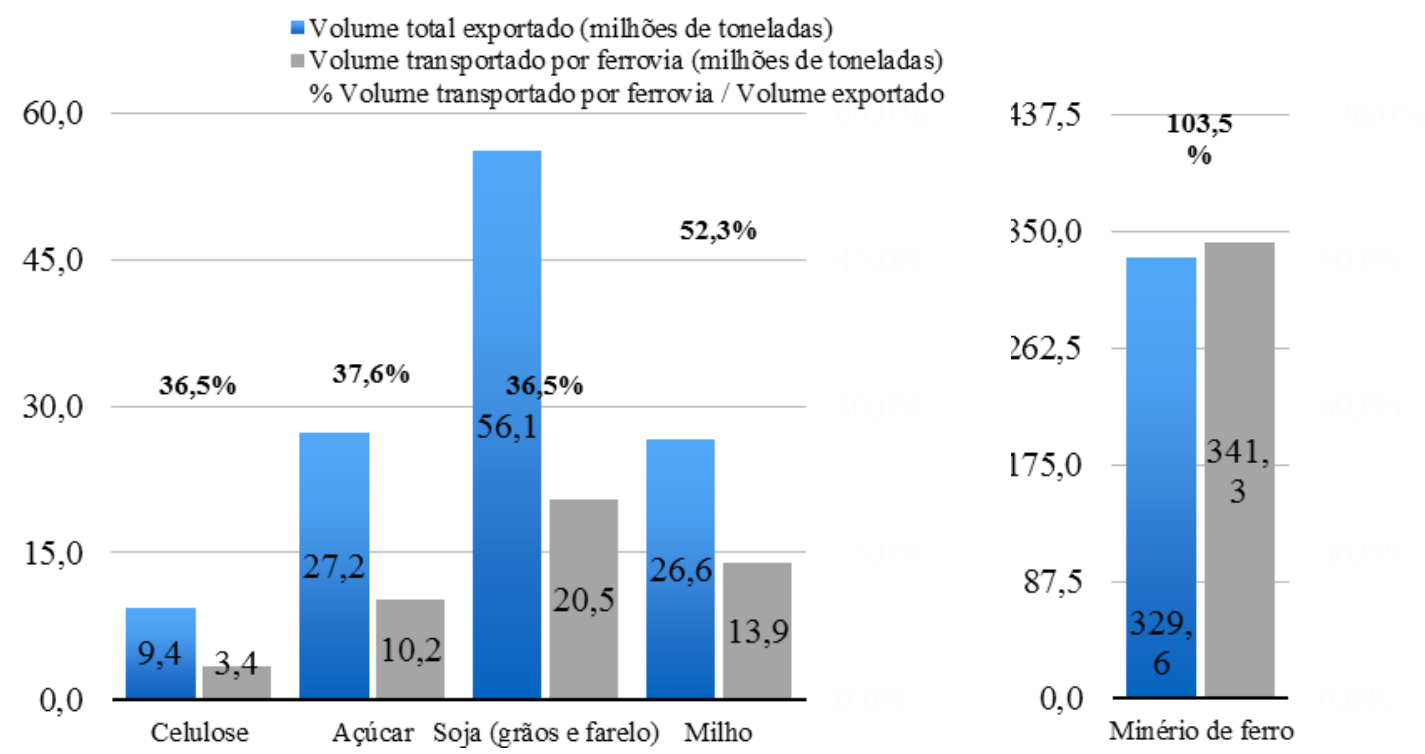

Fonte: Aliceweb/MDIC (2014), BRACELPA (2014), UNICADATA (2014), ANTT (2014c)

\footnotetext{
${ }^{14}$ Cabe mencionar que alguns produtos, como é o caso do minério de ferro, têm sua viabilidade econômica comprometida caso não tenham acesso a modais de transporte alternativos ao rodoviário/aéreo. Por esta razão estas mercadorias são denominadas cargas cativas.
} 


\subsection{COMPROMETIMENTO DA COMPETITIVIDADE DAS COMMODITIES AGRÍCOLAS BRASILEIRAS}

O frete interno ${ }^{15}$ constitui uma parcela significativa do preço total de exportação das commodities agrícolas brasileiras, tendo em vista dois aspectos: as elevadas distâncias que necessitam ser percorridas entre as regiões produtoras e os portos para o embarque internacional e o seu baixo valor agregado. Pela própria definição de commodity - bens homogêneos com preços negociados em mercados internacionais com forte concorrência, aumentos nos valores de frete não podem ser proporcionalmente repassados aos consumidores. A forte dependência no modal rodoviário, em função do acesso limitado a modais alternativos, provoca sérios constrangimentos ao potencial produtivo do Brasil, afetando, desta forma, a competitividade dos produtos nacionais frente aos concorrentes estrangeiros.

Para efeito de exemplificação, adicionalmente ao mencionado prejuízo à competitividade do milho brasileiro como consequência das limitações logísticas do país, tem-se o caso da soja; conforme mencionado, um dos principais produtos da pauta exportadora nacional. Do total de 42,8 milhões de toneladas de soja em grão exportado pelo Brasil em 2013, 70\% foi destinado ao mercado chinês. Entre os estados produtores, quatro tiveram destaque, com participação total superior a $70 \%$ : Mato Grosso $(28,7 \%)$, Rio Grande do Sul (18,4\%), Paraná $(17,6 \%)$ e Goiás $(7,4 \%)$.

Apesar de ser uma das principais regiões produtoras do país, grande parte da competitividade do produto oriundo do norte mato-grossense se perde no transporte interno até alcançar um porto de embarque. De fato, de acordo com informação constante em

\footnotetext{
${ }^{15}$ Além dos custos de transporte, os custos logísticos envolvem custos de administração, armazenagem, estoque e trâmites legais. De acordo com benchmark latino-americano realizado por GUASCH (2010), para produtos agroindustriais, os custos de transporte interno representam, em média, 16\% dos custos logísticos, que, por sua vez, respondem, em média, por $24 \%$ do valor do produto.
} 
relatório publicado pelo USDA (2014), em 2013, a soja do norte do Estado de Mato Grosso foi transportada ao Porto de Santos a um custo médio de US\$ 116,40/t (2,8 vezes o custo do transporte marítimo do mesmo porto para o Porto de Shangai ${ }^{16}$ ); enquanto o produto do sul do Estado de Goiás foi transportado ao mesmo porto a um custo médio de US\$ 58,90/t; para o transporte do grão proveniente do noroeste do Estado do Rio Grande do Sul até o Porto de Rio Grande, foram gastos, em média, US\$ 41,52/t; enquanto o custo médio de deslocamento da soja entre o centro-norte do Estado do Paraná e o Porto de Paranaguá foi de US\$ 32,26/t.

Considerando-se preços CIF $^{17}$ da soja com destino ao Porto de Shangai, em 2013, os valores totais médios por tonelada e as participações dos custos de transporte nos custos agregados totais ${ }^{18}$ foram, respectivamente, os seguintes: US\$ 644,80/t e 28,4\%, para o produto do norte do Estado de Mato Grosso; US\$ 603,76/t e 13,9\%, para o produto do centronorte do Estado do Paraná; US\$ 584,52/t e 18,9\%, no caso do grão proveniente do sul do Estado de Goiás; e US\$ 558,73/t e 12,3\%, para a oleaginosa produzida no noroeste do Estado do Rio Grande do Sul.

Esses números podem ser confrontados com os referentes à exportação da soja norteamericana embarcada ao mesmo porto chinês: US\$ 604,28/t e $15,4 \%$, para o produto do Estado de Minnesota; e US\$ 604,46/t e 14,3\%, para o grão proveniente do Estado de Iowa. Desta forma, verifica-se a perda de competitividade dos produtos mato-grossense e goiano, como consequência dos elevados custos logísticos associados ao transporte interno até os portos para exportação. ${ }^{19}$

\footnotetext{
${ }^{16}$ Frete marítimo médio em 2013 para o Porto de Shangai, conforme porto de origem: Santos, US\$ 40,96/t; Paranaguá, US\$ 43,88/t; Rio Grande, US\$ 41,52/t. (USDA, 2014)

${ }^{17}$ CIF: Produto, Seguros e Frete.

${ }^{18}$ Os valores totais consideram apenas o produto, transporte interno e transporte marítimo.

${ }^{19}$ Cf. USDA (2014)
} 
Salienta-se que no caso do milho, os custos de transporte têm impacto ainda maior no valor do produto, levando-se em consideração o fato de que o preço unitário do cereal é de, aproximadamente, $50 \%{ }^{20}$ do preço da oleaginosa.

Observa-se, deste modo, que os elevados custos logísticos afetam a competitividade do país, a ponto de inviabilizar maiores incrementos nas exportações, mesmo no caso de produtos em que o Brasil tem reconhecidamente vantagens comparativas, tendo impacto direto e evidente na limitação ao crescimento do produto nacional.

${ }^{20}$ Considerando-se valores médios do período 2002-2013. 


\section{REGULAÇÃO DA INFRAESTRUTURA E ORGANIZAÇÃo DO SETOR FERROVIÁRIO}

\subsection{REGULAÇÃO DA INFRAESTRUTURA: ASPECTOS TEÓRICOS}

\subsubsection{MONOPÓLIO NATURAL}

Tradicionalmente, vários segmentos do setor de infraestrutura eram caracterizados como monopólios naturais. Conforme WALRAS (1897 apud LAFFONT; MARTIMORT, 2002, p.18), monopólio natural pode ser definido como um setor no qual o monopólio é a estrutura de mercado eficiente, de tal forma que uma única empresa pode ofertar um bem/serviço a um custo total médio inferior a aquele que se teria caso existissem empresas concorrentes (PINDYCK; RUBINFELD, 2009).

Diversos autores atribuem a mencionada eficiência à existência de economias de escala $^{21}$ e de escopo ${ }^{22}$ em relação ao tamanho do mercado. GÓMEZ-IBAÑEZ (2003) ${ }^{23}$ concorda com esta afirmação, mas pondera que ela ocorre, sobretudo, como consequência de fatores como longo período de amortização e da especificidade do investimento ${ }^{24}$ que provocam elevada barreira à entrada de competidores, e assinala que monopólios naturais

\footnotetext{
${ }^{21}$ Cf. PINDYCK e RUBINFELD (2009, p.246), entende-se economias de escala como a situação em que é possível obter o dobro de produção por menos que o dobro dos custos.

${ }^{22}$ Cf. PINDYCK e RUBINFELD (2009, p.250), entende-se economias de escopo como a situação em que a produção conjunta de uma firma é maior do que aquela que se teria com duas empresas diferentes, cada uma produzindo um único produto. No setor ferroviário, o conceito é aplicado, por exemplo, para a prestação de serviços de transporte de cargas e de passageiros.

${ }^{23}$ GÓMEZ-IBAÑEZ (2003, p.8)

${ }^{24}$ Cf. WILLIAMSON (1989, p.142), a especificidade do ativo diz respeito ao grau com que um ativo pode ter usos alternativos sem prejuízos a seu valor produtivo.
} 
costumam ocorrer em mercados onde os custos fixos são muito maiores que os custos variáveis $^{25}$

Segundo JOSKOW $(2005)^{26}$, mercados com atributos de monopólio natural tendem a produzir problemas de desempenho econômico diversos, tais como preços excessivos, ineficiências na produção, serviços de baixa qualidade, além de impactos distributivos potencialmente indesejáveis. Neste contexto, notam-se efeitos do poder de mercado normalmente exercido pelas firmas monopolistas.

GÓMEZ-IBAÑEZ $(2003)^{27}$ define poder de mercado como o grau no qual uma firma pode elevar os preços de seus produtos acima dos custos de produção, sem perdas significativas nas vendas. O problema que se coloca, conforme abordado por WILLIAMSON (1975), é a possibilidade de que as firmas que detenham poder de mercado tenham metas estratégicas não convergentes com o bem-estar da sociedade.

O poder de mercado pode ser exercido, por exemplo, através de discriminação de preços, elevação de barreiras à entrada, ou estratégias predatórias. Da mesma forma, as firmas podem se utilizar da verticalização como meio para transferir seu poder de mercado entre as diferentes etapas da cadeia produtiva. No entanto, cabe destacar, conforme GÓMEZIBAÑEZ $(2003)^{28}$, que o poder de mercado não é uma característica fixa, mas pode variar ao longo do tempo e de acordo com o tipo de cliente, a organização da indústria e as circunstâncias específicas em que a firma se encontra.

\footnotetext{
${ }^{25}$ Cf. THE WORLD BANK (2014), os custos fixos de uma ferrovia (infraestrutura, terminais) representam pelo menos 70\% do seu custo total. Para CAMPOS e CANTOS (2000 apud DI PIETRANTONIO e PELKMANS, 2004, p.12), esses custos são ainda maiores, alcançando $90 \%$ do custo total.

${ }^{26}$ JOSKOW $(2005$, p.1)

${ }^{27}$ GÓMEZ-IBAÑEZ (2003, p.6)

${ }^{28}$ GÓMEZ-IBAÑEZ (2003, p.7)
} 
Como forma de proteger a sociedade dos problemas resultantes da condição de monopólio natural característica do setor de infraestrutura, os governos normalmente adotam soluções variadas associadas a níveis crescentes de intervenção ${ }^{29}$, que vão desde a aprovação de marco jurídico relativo à celebração e execução de contratos privados, passando pela regulação de preços e qualidade dos serviços, condições de entrada e saída do mercado, até a provisão direta da infraestrutura à sociedade.

Na Figura 6 tem-se o esquema teórico associado a uma firma monopolista, que apresenta custo marginal (MC) constante e menor que o custo médio (AC). AC é influenciado pelo custo fixo, que se dilui à medida que a quantidade cresce. Caso a firma estabeleça o preço no ponto onde a curva do custo marginal intercepta a curva de demanda solução "first best" ${ }^{\text {30 }}$, ela teria um déficit operacional indicado pela área do retângulo AEBP (Gráfico A) e que corresponde exatamente ao custo fixo total, ensejando algum tipo de compensação (por exemplo, subsídio governamental). Essa solução caracterizaria, por exemplo, a provisão direta de infraestrutura à sociedade. No caso de mercado desregulamentado, o monopolista tenderia a ofertar a quantidade correspondente ao ponto em que o custo marginal se iguala à receita marginal, a um preço $\mathrm{P}_{\mathrm{M}}$, o que geraria perdas de eficiência ao mercado, medida pelo peso morto ("deadweight loss") representado pela área do triângulo MBF (Gráfico B). Com a regulação, o objetivo é fazer com a empresa seja remunerada por seus custos fixos. Desta forma, o preço $(\mathrm{G})$ é determinado a partir do ponto onde as curvas de custo médio (AC) e de demanda se cruzam, resultando em menor peso morto, equivalente à área do triângulo GBH (gráfico B), caracterizando uma solução "second best”. (PITTMAN, 2003)

\footnotetext{
${ }^{29}$ GÓMEZ-IBAÑEZ (2003, p.11)

${ }^{30}$ Ou Pareto eficiente. Cf. PINDYCK e RUBINFELD (2009, p.590) pode ser definido como a alocação na qual ninguém consegue estar melhor sem que pelo menos um esteja pior.
} 
Figura 6 - Esquema teórico: formação de preço de uma empresa monopolista
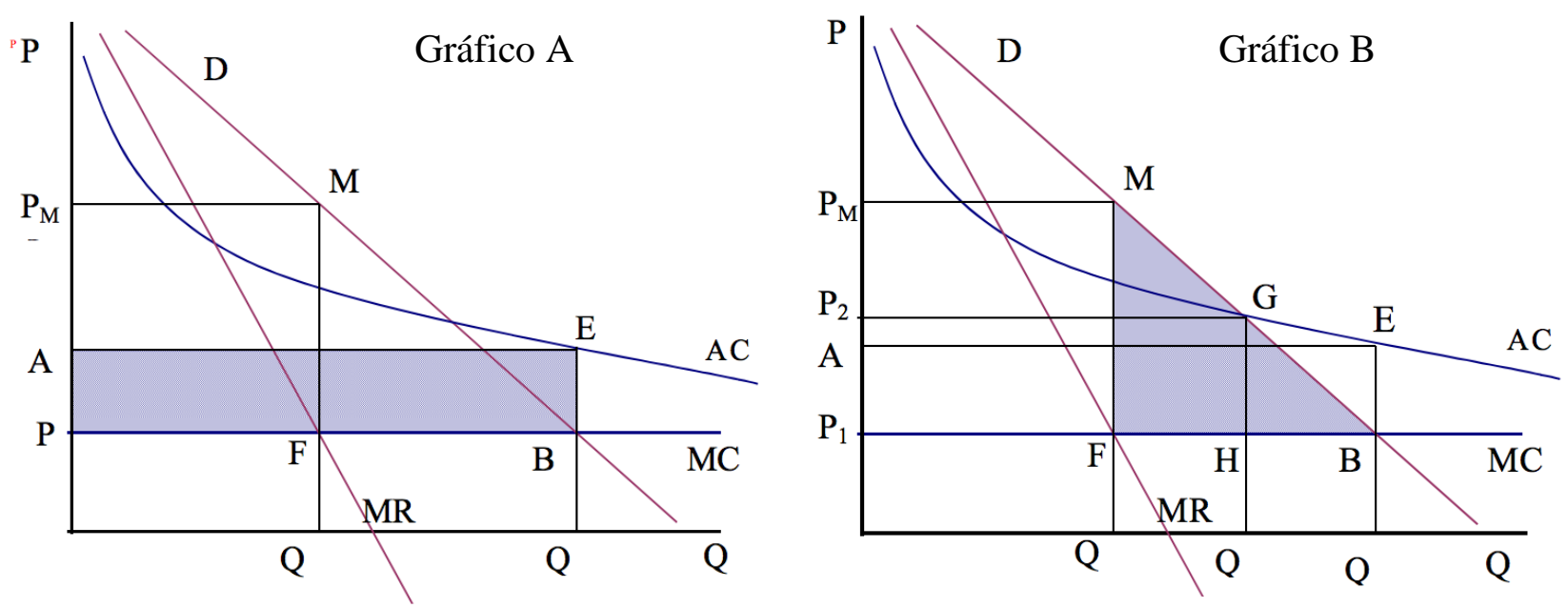

Fonte: PITTMAN (2003)

Como a provisão estatal de monopólios naturais está sujeita a ineficiências geradas por uma gestão politizada ou pela falta de incentivos a aumentos de produtividade e qualidade $^{31}$, entende-se que a produção privada se mostra como a melhor opção, sendo ainda possível sugerir que o emprego de regulação econômica é essencial, dado que a competição não é um mecanismo regulatório viável ${ }^{32}$ e a desregulamentação completa pode resultar em abusos de poder de mercado por parte dos monopolistas ${ }^{33}$.

\footnotetext{
${ }^{31}$ Cf. POSSAS; FAGUNDES; PONDRÉ (1998)

${ }^{32}$ Nota-se que autores como POSNER (1969, p.549) entendem que os benefícios da regulação governamental não superam os respectivos custos e mesmo nos mercados em que o monopólio é a estrutura mais eficiente, seria mais adequado liberar para que as forças econômicas naturais determinassem a conduta e desempenho empresarial sujeitos apenas a restrições de política antitruste.

${ }^{33}$ Cabe mencionar que DEMSETZ (1968b), STIGLER (1968) e POSNER (1972) (apud WILLIAMSON, 1989, p.175) entendem que o preço de monopólio poderia ser evitado por meio de licitação ex-ante para outorga do serviço à firma que ofereça a melhor proposta sob as melhores condições. Neste caso, concluem que poder-se-ia prescindir da regulação do Estado.
} 


\subsubsection{CONTRATOS}

Conforme mencionado, os investimentos em infraestrutura têm entre suas características longo período de amortização e especificidade de ativo, implicando em maiores riscos e incertezas. Como consequência, contratos de concessão de infraestrutura envolvem elevados custos de transação que não podem ser negligenciados - no conceito desenvolvido por autores da Nova Economia Institucional como COASE (1960), WILLIAMSON (1989), NORTH (1990). COASE (1960) explicita este conceito da seguinte forma:

“Com vistas a conduzir uma transação mercadológica, é necessário descobrir com quem é que se quer negociar, informar que se deseja negociar e em que condições, conduzir negociações iniciando a barganha, elaborar um contrato, verificar para assegurar-se que os termos do contrato estão sendo observados, e assim por diante. "34

DAHLMAN (1979) ${ }^{35}$, por sua vez, classifica os custos de transação em três categorias:

- custos de busca e informação ("search and information costs"): referem-se aos custos incorridos na determinação da disponibilidade do produto demandado no mercado, sobre quem tem o menor preço, etc. Incluem os custos de prospecção, comparação da relação qualidade-preço entre diferentes propostas, estudos de mercado, etc.

- custos de negociação e decisão ("bargaining and decision costs"): referem-se aos custos incorridos para encontrar agentes econômicos que estejam dispostos a realizar uma transação sob certas condições a determinado preço. Incluem os custos envolvidos para se

\footnotetext{
${ }^{34}$ Cf. COASE (1960, p.15). Tradução livre, a partir do texto: "In order to carry out a market transaction it is necessary to discover who it is that one wishes to deal with, to inform people that one wishes to deal and on what terms, to conduct negotiations leading up to a bargain, to draw up the contract, to undertake the inspection needed to make sure that the terms of the contract are being observed, and so on."

${ }^{35}$ Cf. DAHLMAN (1979, p.148)
} 
alcançar um acordo aceitável com a outra parte da transação como, por exemplo, a redação de um contrato apropriado.

- custos de fiscalização e monitoramento ("policing and enforcement costs"): são os custos incorridos para garantir que a outra parte cumpra os termos do contrato ou para a tomada das ações necessárias, em caso de as condições não serem respeitadas. Envolve o controle de qualidade, a verificação da entrega, etc.

Neste contexto, a teoria da economia dos custos de transação considera que a construção de contratos não padronizados agrega eficiência, além de dar ênfase à fase de execução contratual. Ademais, a teoria ressalta a importância da propriedade e do alinhamento ex-ante de incentivos. Para tanto, destaca a relevância das instituições de suporte ex-post ao contrato. Outro aspecto que cabe ser mencionado é que a teoria reconhece a existência de conflitos potenciais e propõe estruturas de governança que possam atenuar ou mesmo preveni-los (WILLIAMSON, 1985) ${ }^{36}$.

Os custos de transação ocorrem por duas razões: i) em função da impossibilidade de que as partes envolvidas em uma transação tenham conhecimento pleno de todos os fatos relevantes ou antecipem todas as possíveis situações de contingência futura - incerteza ou racionalidade limitada ${ }^{37}$; ii) pelo fato de ser possível que ao menos uma das partes tenha comportamento intencionalmente racional e oportunista. A princípio, estes dois aspectos parecem ser contraditórios, mas, de fato, não são. Eles representam pressupostos comportamentais que devem ser considerados nas negociações contratuais, ao retratar a intenção pela racionalidade (comportamento estratégico), que é desafiada pelas limitações impostas pela realidade (possibilidade de ocorrência de imprevistos).

\footnotetext{
${ }^{36}$ WILLIAMSON (1985, p.29)

${ }^{37}$ Conceito de "bounded rationality" definido por SIMON (1982, p.291)
} 
Observa-se que o comportamento oportunista pode estar associado a problemas de seleção adversa ou conhecimento não revelado, caracterizando um problema de informação assimétrica, ou a problemas de risco moral ou ação oculta (ou não revelada) ${ }^{38}$. Problemas de seleção adversa são causados quando agentes possuem mais informação que o principal sobre variáveis exógenas, como é o caso de agentes que conhecem melhor os custos associados à construção de uma ferrovia que o concedente. Já problemas de risco moral estão relacionados a variáveis endógenas não observadas pelo regulador ${ }^{39}$ e podem lidar, por exemplo, com questões relacionadas ao desconhecimento do nível de esforço do agente pelo principal (regulador), que podem afetar o custo ou a qualidade de seus produtos. Como o nível de esforço não pode ser observado, o que os contratos podem ser contingentes é com relação ao desempenho.

É conveniente esclarecer que o comportamento oportunista na relação principalagente também pode surgir no sentido inverso, do principal para com o agente. A inexistência de uma política previsível de longo prazo, por exemplo, gera um problema de comprometimento onde, por um lado, os governos não enxergam além da próxima eleição ${ }^{40} \mathrm{e}$ por outro, os reguladores têm incentivos para expropriar os investimentos "sunk cost" (custos afundados) realizados pelas empresas. GÓMEZ-IBAÑEZ $(2003)^{41}$ assinala que a parte que realiza investimentos duráveis e específicos está vulnerável a oportunismos, e sugere que contratos de longo prazo que compatibilizem o prazo com a vida útil da infraestrutura contribuem para a redução desse oportunismo.

\footnotetext{
${ }^{38}$ LAFFONT; MARTIMORT (2002, p.12)

${ }^{39}$ LAFFONT; TIROLE (1993, p.1)

${ }^{40}$ Cf. BAER (1988), com as tarifas controladas - inclusive do setor de transportes - não acompanhando o ritmo da inflação, o capital privado absteve-se de expandir suas instalações.

${ }^{41}$ GÓMEZ-IBAÑEZ (2003, p.250)
} 
Deste modo, considerando-se objetivos conflitantes e informação incompleta, os contratos devem promover a compatibilidade entre incentivos e a racionalidade individual, tendo em vista que os agentes agem de forma a atender seus próprios interesses. ${ }^{42}$ Conforme WILLIAMSON (1985), o contrato mais adequado, em termos de eficiência econômica, é aquele que se baseia em mecanismos de incentivo e níveis de desempenho e em uma alocação de riscos que leve em consideração qual das partes melhor lida com cada risco.

\subsubsection{MÉTODOS REGULATÓRIOS}

A atividade regulatória tem como objetivo, por um lado, proteger o usuário do serviço, e por outro, assegurar a estabilidade das regras de operação de mercado para os concessionários do direito à exploração desse serviço, garantindo o respeito aos contratos e o uso adequado de incentivos à eficiência, expansão dos serviços e modicidade tarifária. ${ }^{43}$

Em geral, a regulação governamental de monopólios naturais costuma focar-se em três aspectos, quais sejam: preço, qualidade e condições de entrada e saída.

Os mecanismos mais comumente utilizados na regulação tarifária do setor ferroviário são: regulação por taxa de retorno e regulação por price cap ${ }^{44}$.

$\mathrm{Na}$ regulação por taxa de retorno (RTR), as tarifas devem ser suficientes para remunerar os custos totais e proporcionar um nível de retorno ao investidor compatível com o obtido por outros empreendimentos de risco similar. Os principais problemas encontrados na utilização deste mecanismo dizem respeito à presença ou ausência de incentivos: inexistência de incentivos para a minimização dos custos e melhoria na qualidade dos serviços; incentivo

\footnotetext{
${ }^{42}$ HERMALIN (1993 apud SALGADO, 2003, p.12)

${ }^{43}$ SALGADO e MOTTA (2005, p.5)

${ }^{44}$ Conceito proposto por LITTLECHILD (1983 apud STERN, 2003)
} 
ao sobreinvestimento ${ }^{45}$, dado que o retorno é função da base de ativos; e baixo incentivo para ganhos de eficiência e melhorias tecnológicas.

O mecanismo de price cap (PCR), também conhecido como RPI-X, tem por objetivo a introdução de estímulos à eficiência produtiva, por meio da definição de um preço teto, que é corrigido por um índice de preços, subtraído de um percentual equivalente ao fator de produtividade $(\mathrm{X})$, de forma a promover o compartilhamento de ganhos de produtividade entre o regulado e o usuário.

CAMPOS e CANTOS (2000) ${ }^{46}$ afirmam que um dos pontos mais críticos do mecanismo está relacionado ao estabelecimento do fator $\mathrm{X}^{47}$ e sugerem a utilização de indicadores ou índices para medir a diferença entre as taxas de crescimento da produção e do consumo de insumos. Os autores apresentam, ainda, uma lista com os principais indicadores utilizados para avaliar o desempenho no setor ferroviário.

Conforme advertem LAFFONT e TIROLE (1993) ${ }^{48}$, a regulação por price cap requer por parte do regulador bom conhecimento do custo e condições de demanda do empreendimento, dado que caps muito elevados fazem com que a firma atue como monopolista em ambiente desprovido de regulação, enquanto caps muito baixos podem comprometer a viabilidade do negócio.

Dentre os principais benefícios associados à utilização do PCR estão: incentivos para maior eficiência por parte da firma; simplificação do processo regulatório; maior flexibilidade na estrutura de preços; limitação da intervenção do regulador na operação cotidiana do operador; benefícios de ganhos de produtividade tanto ao operador como ao

\footnotetext{
${ }^{45}$ Fenômeno de viés de capital conhecido como Averch-Johnson. (LUCINDA, 2010)

${ }^{46}$ CAMPOS e CANTOS (2000, p.28)

${ }^{47}$ Cf. LAFFONT e TIROLE (1993, p.18), o fator X deve refletir a taxa de progresso tecnológico, devendo ser calculada de forma exógena.

${ }^{48}$ LAFFONT e TIROLE (1993, p.17)
} 
usuário; proteção dos consumidores e dos competidores por meio da limitação do aumento de preços; e limitação da possibilidade de subsídios cruzados ${ }^{49}$. SAINTIVE e CHACUR $(2006)^{50}$ apontam as duas principais desvantagens do mecanismo como sendo a possível redução nos níveis de investimento e na qualidade dos serviços que não são passíveis de determinação pelo órgão regulador; e problemas relacionados à assimetria de informação nos períodos de revisão tarifária.

Ao comparar estes dois mecanismos de regulação tarifária, BEESLEY e LITTLECHILD (1989 apud RESENDE, 1997) ${ }^{51}$ identificam quatro vantagens do PCR vis-àvis o RTR: período de revisão tarifária fixo, abordagem prospectiva (forward looking $)^{52}$, graus de liberdade mais amplos e menor necessidade de explicações por parte do regulador.

A forma mais comumente utilizada de regulação da qualidade implica no estabelecimento de padrões de qualidade do serviço a serem atendidos pelo regulado. No caso do setor ferroviário, por exemplo, pode envolver o acompanhamento da produção ferroviária e do índice de acidentes, conforme adotado nos contratos de concessão das malhas da antiga RFFSA. Cabe mencionar que, conforme CAMPOS e CANTOS (2000) ${ }^{53}$, a qualidade do serviço pode ser impactada pelo modelo de regulação tarifária adotado. Por exemplo, enquanto o RTR pode favorecer a oferta de serviços de maior qualidade, o PCR pode implicar em serviços de menor qualidade.

A outorga do direito de exploração por meio de contratos de concessão se caracteriza como um mecanismo para inibir a entrada de agentes no mercado, dada a condição de

\footnotetext{
${ }^{49}$ LUCINDA (2010)

${ }^{50}$ SAINTIVE e CHACUR (2006, p.10)

${ }^{51}$ RESENDE (1997, p.652)

${ }^{52}$ Cf. LAFFONT e TIROLE (1993, p.17) na abordagem prospectiva, os custos históricos não devem servir de base para a definição de preços futuros.

${ }^{53}$ CAMPOS e CANTOS (2000, p.30)
} 
monopólio como estrutura de mercado eficiente. Adicionalmente, as condições de saída também são normalmente reguladas, com vistas a evitar a descontinuidade da prestação do serviço público.

\subsection{ORGANIZAÇÃO DO SETOR FERROVIÁRIO}

A provisão do serviço público ferroviário de cargas pode ser melhor descrita a partir da distinção entre as atividades de exploração da infraestrutura ferroviária e de prestação do serviço de transporte ferroviário de cargas. A infraestrutura ferroviária engloba as instalações, obras de arte, infraestruturas, superestruturas, sistemas de sinalização e comunicação, entre outros. A exploração da infraestrutura ferroviária envolve a construção, instalação, recuperação e manutenção da infraestrutura ferroviária e o controle do licenciamento e da circulação de comboios. A prestação do serviço de transporte ferroviário de cargas compreende, por sua vez, a movimentação de mercadorias, de qualquer natureza, de um ponto a outro, e requer a aquisição/leasing e manutenção de material rodante. Adicionalmente, a provisão do serviço ferroviário de cargas pode abarcar operações acessórias como carregamento, descarregamento, manobra e armazenagem.

Até recentemente, a análise da organização do setor ferroviário se resumia a aspectos relacionados à dualidade ferrovia sob gestão privada x pública. Aos poucos, novos arranjos foram sendo desenvolvidos nos diferentes países, orientados pelas realidades específicas enfrentadas por cada um, de tal modo que atualmente podem ser encontrados múltiplos arranjos organizacionais, inclusive no contexto de um mesmo país. Como consequência, a classificação das formas possíveis de organização setorial não é tarefa simples. Na Tabela 3 apresenta-se um resumo resultante de exercício de classificação realizado com base em trabalho publicado pela OECD (2013). 
Tabela 3 - Organização funcional do setor ferroviário (Exploração da infraestrutura e prestação do serviço de transporte)

\begin{tabular}{|c|c|c|c|c|}
\hline Estrutura & $\begin{array}{c}\text { Foco da } \\
\text { Regulação }\end{array}$ & Atuação & Concorrência & Exemplos \\
\hline Vertical & $\begin{array}{l}\text { Tarifas cobradas } \\
\text { dos usuários }\end{array}$ & $\begin{array}{lr}\text { A } & \text { mesma } \\
\text { instituição } & \text { é } \\
\text { responsável pela } \\
\text { exploração da } \\
\text { infraestrutura } \\
\text { ferroviária e } & \text { da } \\
\text { operação } & \text { do } \\
\text { serviço } & \text { de } \\
\text { transporte } & \end{array}$ & Intermodal & $\begin{array}{l}\text { América Latina, } \\
\text { Estados Unidos } \\
\text { (ferrovias Classe } \\
\text { I), Canadá (CP e } \\
\mathrm{CN} \text { ), China, } \\
\text { Índia, Turquia }\end{array}$ \\
\hline $\begin{array}{l}\text { Separação } \\
\text { Vertical }\end{array}$ & $\begin{array}{l}\text { Acesso à via } \\
\text { pelo operador } \\
\text { ferroviário } \\
\text { (tarifa } \\
\text { condições }\end{array}$ & $\begin{array}{l}\text { Uma instituição } \\
\text { é responsável } \\
\text { pela exploração } \\
\text { da infraestrutura } \\
\text { ferroviária }\end{array}$ & $\begin{array}{l}\text { Intermodal } \\
\text { intramodal } \\
\text { maior parte } \\
\text { casos } \\
\text { casos) }\end{array}$ & $\begin{array}{l}\text { Modelo da } \\
\text { União Europeia } \\
\text { (UE), adotado } \\
\text { pela maioria de } \\
\text { seus Estados- }\end{array}$ \\
\hline & acesso) & $\begin{array}{l}\text { enquanto a } \\
\text { operação do } \\
\text { serviço de } \\
\text { transporte está a } \\
\text { cargo de outra(s) } \\
\text { instituição(ões). }\end{array}$ & & $\begin{array}{l}\text { Membros } \\
\text { Austrália. }\end{array}$ \\
\hline
\end{tabular}

Fonte: OECD (2013), com adaptações

\subsubsection{MODELO VERTICAL DE EXPLORAÇÃO DE SERVIÇOS FERROVIÁRIOS}

A integração vertical ocorre quando uma empresa opera em mais de uma etapa de seu processo produtivo. Na exploração do serviço ferroviário de cargas, isso significa que uma mesma instituição é responsável tanto pela exploração da infraestrutura ferroviária como pela provisão do serviço de transporte. Em certos casos, inclusive, a ferrovia pode ser vista como parte cadeia produtiva, como na indústria do minério de ferro. Dentre as motivações que 
levam as firmas a adotarem a verticalização de seu processo produtivo, destacam-se: economias tecnológicas, poder de mercado e economias transacionais.

PORTER (1979) propôs um modelo de análise de indústrias, em que considera a existência de cinco forças atuantes nos mercados - poder dos fornecedores, poder dos clientes, grau de rivalidade entre os concorrentes, barreiras à entrada e ameaça de substitutos. Utilizando-se esse modelo, o modelo vertical de exploração ferroviária de cargas pressupõe as seguintes características:

- rivalidade limitada, em função do monopólio local exercido pelas empresas concessionárias;

- reduzido poder dos fornecedores;

- reduzido poder dos clientes;

- elevadas barreiras à entrada, tendo em vista o elevado custo de capital necessário para a construção de linhas férreas e a provisão de material rodante;

- reduzida ameaça de serviços substitutos para o transporte de produtos cativos do transporte ferroviário. Para mercadorias não cativas da ferrovia, a concorrência intermodal pode ser relevante, especialmente com o modal rodoviário.

Conforme comentado, o poder de mercado pode variar de acordo com o cliente. Neste sentido, os operadores do serviço de transporte ferroviário, por exemplo, exercem menor poder de mercado sobre embarcadores de produtos de maior valor agregado - na comparação com embarcadores de mercadorias de baixo valor, o mesmo ocorrendo sobre aqueles que necessitam transportar grandes volumes por menores distâncias - na comparação com aqueles que dependem do transporte por distâncias maiores.

A regulação das empresas ferroviárias que operam sob o modelo vertical tem como foco principal as tarifas cobradas dos usuários, conforme indicado na Tabela 3, com vistas a coibir a prática de preços de monopólio. 
O modelo vertical foi adotado/mantido durante o processo de privatização das administrações ferroviárias pelos países latino-americanos (incluindo o Brasil), nas ferrovias Classe I norte-americanas e nas ferrovias canadenses operadas pela Canadian Pacific (CP) e Canadian National $(\mathrm{CN})^{54}$. Da mesma forma, as ferrovias da China, Índia e Turquia são verticalmente integradas, sendo, no entanto, controladas e operadas por uma única empresa/agência estatal, classificadas, deste modo, como organizações monolíticas (OECD, 2013). DI PIETRANTONIO e PELKMANS (2004) ${ }^{55}$ sugerem que as ferrovias seriam melhor gerenciadas por meio de uma única empresa verticalmente integrada, em face de fatores relacionados ao acúmulo de conhecimento e segurança, mas pondera que a integração completa teria como efeito o fechamento à concorrência.

Vale mencionar que em algumas ferrovias do Canadá (operadas pela Via Rail) e Estados Unidos (operadas pela Amtrack) são encontradas variações do modelo vertical, denominado acesso competitivo ("competitive access" $"$ ). Em ambas as malhas, as estatais são responsáveis pela gestão da infraestrutura ferroviária e pela prestação do serviço de transporte de passageiros. No entanto, no caso canadense, a Via Rail ${ }^{57}$ permite o acesso de operadores independentes exclusivamente para a prestação do serviço de transporte de cargas - denotando a presença de separação horizontal, enquanto a Amtrack, em certas linhas, também permite o acesso de outros operadores ferroviários de passageiros.

Outro caso que merece comentário é o da Rússia, onde a estatal Russian Railways tem atuação como empresa verticalmente integrada. Em 2001 o país deu início a uma reforma

\footnotetext{
${ }^{54}$ Vale destacar que tanto os Estados Unidos como o Canadá possuem muitas linhas ferroviárias paralelas. (DI PIETRANTONIO; PELKMANS, 2004, p.9). Mapas das ferrovias desses países disponível em: <http://www.tgaassoc.com/documents/maps-of-north-american-railways.pdf $>$

55 DI PIETRANTONIO e PELKMANS (2004, p.13)

${ }^{56}$ Diz respeito a administrações ferroviárias concorrentes que têm controle exclusivo sobre os trilhos e também têm o direito (e provê) de acesso aos trilhos de outra concessionária.

${ }^{57}$ A maior parte das operações da Via Rail é realizada por meio de acesso à ferrovias sob responsabilidade de terceiros. Fonte: http://www.viarail.ca/en/about-via-rail/access-to-information/info-source
} 
estrutural do setor ferroviário com o objetivo de promover a concorrência intramodal. Neste sentido, foi aprovada a abertura, a partir de 2004, do acesso à infraestrutura por novos operadores. Desde então, mais de 200 operadores de serviço de transporte ferroviário de carga receberam autorização, contudo, na prática, a concorrência não se efetivou. (OECD, $2013)^{58}$

\subsubsection{SEPARAÇÃO VERTICAL ("UNBUNDLING") DA EXPLORAÇÃO DE SERVIÇOS FERROVIÁRIOS}

Tradicionalmente atividades como a prestação de serviços de telecomunicações e energia elétrica eram classificadas como monopólios naturais. Neste contexto, a concorrência intrasetorial era restrita, pois dependia da duplicação de redes e estruturas. A partir da década de 1980, iniciou-se na Inglaterra, sendo replicado em várias partes do mundo, um movimento de reestruturação organizacional em diversos subsetores de infraestrutura (energia elétrica, gás natural, telefonia, ferrovias, entre outros). Este movimento se baseou no entendimento de que era possível segregar atividades com potencial técnico de se tornarem competitivas daquelas com características de monopólio natural, por meio da separação vertical (“unbundling”). (PERRY, 1989)

A motivação partiu da consideração de que empresas verticalmente integradas podem se aproveitar de sua posição monopolista para prejudicar a concorrência, cometendo abusos

\footnotetext{
${ }^{58}$ Cf. OCDE (2013, p.161), na Irlanda também se verifica situação semelhante à observada na Rússia, em que apesar de vigorar o regime "open access", com a presença de uma estatal monolítica (Iarnród Éireann - Irish Rail), os entrantes não conseguiram obter participação no mercado. Cf. VAN DE VELDE et al. (2012, p. 129), na Lituânia ocorre problema similar.
} 
de poder de mercado. Como solução, a separação vertical poderia favorecer a não discriminação ${ }^{59}$, o aumento da transparência e o fomento à concorrência. (OCDE, 2013)

No setor ferroviário, a principal forma de separação vertical envolve a segregação funcional entre as atividades de exploração da infraestrutura ferroviária e de prestação do serviço de transporte. A atividade com potencial de se tornar competitiva se refere à prestação do serviço de transporte ferroviário ${ }^{60}$, tendo-se nas tarifas e condições de acesso à infraestrutura o foco principal da atuação regulatória, conforme indicado na Tabela 3.

Considerando-se a experiência internacional, reconhecem-se três modelos de implementação da separação vertical entre as atividades de gestão de infraestrutura e as atividades downstream, podendo ser assim classificadas: separação contábil; separação organizacional entre diferentes empresas pertencentes ao mesmo grupo econômico ${ }^{61}$; ou separação institucional entre empresas de grupos distintos ${ }^{62}$. Na Tabela 4 encontram-se exemplos de países que adotaram a separação vertical no setor ferroviário, estando incluída a participação de mercado alcançada pelos operadores entrantes. Com base nestes percentuais, não se observam diferenças significativas em termos de ganhos de market-share por operadores entrantes, na comparação entre países que adotaram a separação organizacional e aqueles que adotaram a separação institucional. Baseado em estudo econométrico, VAN DE VELDE et al. (2012) sugerem que em condição de elevada densidade de tráfego ferroviário, a separação vertical institucional eleva os custos; em baixas densidades, há sinais de que

\footnotetext{
${ }^{59}$ Cf. OCDE (2013), a separação vertical pode não ser tão efetiva com relação à não discriminação, face à necessidade de remunerar os custos fixos e variáveis, o que pode resultar em uma elevada tarifa de acesso.

${ }^{60}$ Cf. CAMPOS e CANTOS (2000, p.6), a infraestrutura tem tratamento de monopólio natural enquanto não estiver construída, contudo, não necessariamente após essa etapa.

${ }^{61}$ Considera-se separação organizacional quando há um gestor de infraestrutura segregado legal e funcionalmente, vinculado a uma holding que detém ao menos um operador ferroviário (KIRCHNER, 2011). Por exemplo, na Alemanha, a holding DB possui uma empresa responsável pela gestão da infraestrutura, outra pelo serviço de transporte de carga e outra pelo serviço de transporte de passageiros.

${ }^{62}$ VAN DE VELDE et al. (2012)
} 
contribua para reduzi-los; e em situações de média densidade de tráfego, a separação vertical institucional não afeta os custos de forma significativa. Adicionalmente, os pesquisadores não encontraram evidências de que a separação vertical institucional seja superior à separação organizacional, em termos de impacto na ampliação da participação do modal ferroviário na matriz de transportes, mas os resultados do estudo indicaram que os problemas de coordenação são maiores no tráfego de cargas na comparação com o transporte de passageiros. Outro aspecto que se nota da Tabela 4 é a generalizada atuação de empresas estatais na exploração da infraestrutura ferroviária, com o monopólio natural sendo gerenciado pelo setor público. 
Tabela 4 - Exemplos de países que adotaram a separação vertical no setor ferroviário, por tipo

Tipo

País (ano de implementação da separação vertical)
Gestor de Infraestrutura Ferroviária Market

share dos

operadore

s de carga

entrantes

2012

$(\%)^{(* 1)}$
VR Track ${ }^{63}$

$0 \%$

Alemanha (2000)

Itália (2001)

Polônia (2001)

Estônia (2004)

Eslovênia (2004)

Áustria (2005)

Bélgica (2005)

Hungria (2007)

Letônia (2007)

Suíça (2009) ${ }^{(* 2)}$

Institucional

Suécia (1988)
Deutsche Bahn Netz AG ${ }^{64}$

$\mathrm{RFI}^{65}$

$29 \%$

PKP PLK ${ }^{66}$

$24 \%$

$33 \%$

EVR Infra (80\%) e Edelaraudtee $30 \%$

Infrastruktuuri $(20 \%)^{67}$

Slovenske železnic Infrastructure $\quad 10 \%$

ÖBB Infrastruktur $\mathrm{AG}^{68} \quad 18 \%$

Infrabel $^{69} \quad 13 \%$

MÁV Co. (94\%) e GySEV $(5 \%)^{70} \quad 32 \%$

SJSC "Latvijas Delzcel̦š" e LLC "LDz $23 \%$

Infrastruktūra" $^{71}$

SBB Infrastrukture (81\%), BLS (11\%), $\quad 32 \%$

Trafikverket $^{73}$

$40 \%$
SOB $(3 \%)$ e outras $(5 \%)^{72}$

\footnotetext{
${ }^{63}$ VR Track é uma subsidiária da estatal VR Group (VAN DE VELDE et al., 2012, p.151).

${ }^{64}$ Deutsche Bahn Netz AG é uma subsidiária da estatal Deutsche Bahn AG (VAN DE VELDE et al., 2012, p.156).

${ }^{65}$ Rete Ferroviaria Italiana SpA (RFI) é uma subsidiária da estatal Ferrovie dello Stato Italiane Group (VAN DE VELDE et al., 2012, p.163).

${ }^{66}$ PKP Polskie Linie Kolejowe S.A (PLK) é uma subsidiária da estatal PLK S.A.

${ }^{67}$ EVR Infra é uma subsidiária da estatal ‘AS Eesti Raudtee’; Edelaraudtee Infrastruktuuri é uma subsidiária da grupo privado ‘Edelaraudtee’ (VAN DE VELDE et al., 2012, p.149).

${ }^{68}$ ÖBB Infrastruktur AG é uma subsidiária da estatal ÖBB Holding AG (VAN DE VELDE et al., 2012, p.143).

${ }^{69}$ Infrabel é uma subsidiária da estatal 'Nationale Maatschappij der Belgische Spoorwegen N.V./ Société Nationale des Chemins de fer Belges (NMBS/SNCB) (VAN DE VELDE et al., 2012, p.145).

${ }^{70}$ MÁV Co. é uma subsidiária da estatal MÁV Co. GySEV é uma subsidiária do grupo controlado pelos governos húngaro e austríaco, além de uma empresa privada (VAN DE VELDE et al., 2012, p.159).

${ }^{71}$ Subsidiárias da estatal LDz (VAN DE VELDE et al., 2012, p.168).

${ }^{72}$ A SBB e a BLS são estatais (VAN DE VELDE et al., 2012, p.181).

${ }^{73}$ Trafikverket é uma agência estatal do governo sueco (VAN DE VELDE et al., 2012, p.179).
} 
Grã Bretanha, exceto Network Rail ${ }^{74}$

Irlanda do Norte (1994)

França (1997)

Noruega (1997)

$\mathrm{RFF}^{75}$

$32 \%$

Portugal (1997)

Romênia (1997)

Norwegian National Rail administration

$\mathrm{n} / \mathrm{d}$ ${\text { (Jernbaneverket })^{76}}^{76}$

Dinamarca (1998)

REFER

$13 \%$

$\mathrm{CFR}^{77} \quad 54 \%$

Bulgária (2001)

Banedanmark $^{78}$

$54 \%$
$27 \%$

Holanda (2002) $)^{80}$

NRIC $^{79}$

$37 \%$

ProRail BV e KeyRail BV ${ }^{81} \quad 36 \%$

Eslováquia (2002)

$\mathrm{ŽSR}^{82}$

$12 \%$

República Checa (2003)

$\mathrm{SŽDC}^{83}$

$21 \%$

Espanha (2005)

$\operatorname{Adif}^{84}$

$13 \%$

Grécia (2010) ${ }^{85}$

$\mathrm{OSE}^{86}$

$\mathrm{n} / \mathrm{d}$

Fonte: VAN DE VELDE et al. (2012) e EUROPEAN COMISSION (2014)

OBS. ${ }^{(* 1)}: \%$ em TKU

OBS. ${ }^{(* 2)}$ : Fonte: KIRCHNER (2011 apud OECD, 2013, p. 38)

A separação vertical pressupõe a liberalização do acesso à infraestrutura a operadores concorrentes $^{87}$. Neste sentido, a entrada de novos operadores ferroviários pode se dar de

\footnotetext{
${ }^{74}$ Cf. VAN DE VELDE et al. (2012, p.157).

${ }^{75}$ A Réseau Ferré de France (RFF) é uma estatal francesa (VAN DE VELDE et al., 2012, p.153).

${ }^{76}$ Cf. VAN DE VELDE et al. (2012, p.171).

${ }^{77}$ Căile Ferate Române S.A. (CFR) é uma estatal romena (VAN DE VELDE et al., 2012, p.175).

${ }^{78}$ Estatal vinculada ao Ministério dos Transportes dinamarquês (VAN DE VELDE et al., 2012, p.147).

${ }^{79}$ National Railway Infrastructure Company (NRIC) é uma estatal vinculada ao Ministério dos Transportes da Bulgária. Fonte: <http://www.rne.eu/country-information-detail/items/4.html>

${ }^{80}$ De 1995 a 2001, a Holanda adotou a separação vertical organizacional (VAN DE VELDE et al., 2012, p.27).

${ }^{81}$ A ProRail é subsidiária da estatal Rail Infra Trust e a KeyRail BV é pertencente ao grupo formado pela ProRail (50\%) e os portos de Roterdam (35\%) e Amsterdam (15\%) (VAN DE VELDE et al., 2012, p.184).

${ }^{82}$ A ŽSR é uma estatal vinculada ao Ministério dos Transportes, Correios e Telecomunicações da Eslováquia. Fonte: <http://www.zsr.sk/anglicky.html?page_id=124>.

${ }^{83}$ A Správa železniční dopravní cesty (SZDC) é uma estatal vinculada ao Ministério dos Transportes da República Checa. Fonte: 〈http://www.szdc.cz/en/index.html〉.

${ }^{84}$ A Adif é uma estatal vinculada ao Ministério do Fomento espanhol (VAN DE VELDE et al., 2012, p.177).

${ }^{85}$ De 2007 a 2009, a Grécia adotou a separação vertical organizacional (VAN DE VELDE et al., 2012, p.27).

${ }^{86}$ Hellenic Railways Organisation (OSE) é uma estatal grega. Fonte: < http://www.ose.gr/en/Home.aspx>
} 
distintas formas: "open access", concorrência, outorga direta ("direct award") ou por meio de privatização de empresa estatal. O “open access" se refere à outorga do direito de acesso à rede ferroviária por múltiplos operadores qualificados, que competem pelo acesso aos trilhos. Além da promoção da concorrência nos trilhos, entende-se que o "open access" favorece a introdução de inovações na atividade ferroviária. A concorrência, também conhecida como "franchising", envolve a alocação temporária do direito de operação de certos serviços ferroviários a determinados operadores, por exemplo, por meio de licitação, ou seja, trata da competição pelos trilhos. (OCDE, 2013)

Exceto quando a separação vertical é do tipo institucional, um dos requisitos primordiais do regime de "open access" é o acesso não discriminatório por operadores entrantes. Neste contexto, a alocação de capacidade de transporte é considerada uma atividade essencial. ${ }^{88}$ Cabe mencionar que em alguns dos países onde não se adotou a separação institucional foram implementados arranjos específicos voltados a garantir a justiça concorrencial e o acesso não discriminatório, dentre os quais se destacam: i) alocação de capacidade sob responsabilidade de instituição distinta do gestor de infraestrutura; ii) aprimoramento de mecanismos regulatórios e de "compliance", com o estabelecimento de regras adicionais. Entre os países que adotaram o primeiro arranjo, podem ser mencionados: Suíça ${ }^{89}$, Hungria, Eslovênia e Holanda (1995 a 2001) ${ }^{90}$. Com relação ao segundo, o mesmo pode ser encontrado em países como Alemanha e Itália. ${ }^{91}$

\footnotetext{
${ }^{87}$ Cabe notar que alguns países adotaram a separação vertical, sem a introdução da concorrência intramodal. Como exemplo, podem ser citadas a Coreia do Sul e a Nova Zelândia (OECD, 2013).

${ }^{88}$ Cf. VAN DE VELDE et al. (2012, p. 11), além da alocação de capacidade, o estabelecimento de tarifas de acesso também é considerada atividade essencial.

${ }^{89}$ Em 2006 foi criada na Suíça a Trasse Schweiz, como uma agência independente responsável pela alocação de capacidade de transporte, controlada pela associação de transporte público suíço e pelas três principais empresas ferroviárias do país (VAN DE VELDE et al., 2012).

${ }^{90}$ A partir de 2002, a Holanda adotou a separação institucional.

${ }^{91}$ Cf. VAN DE VELDE et al. (2012, p.101-107).
} 
Com base na literatura, KUROSAKI $(2008)^{92}$ identifica que as principais vantagens associadas à separação vertical são: facilitação do investimento público em infraestrutura; ampliação das possibilidades de atuação do setor privado; introdução da concorrência intramodal; promoção da especialização das firmas em infraestrutura ou operação; e possibilidade de arranjos financeiros envolvendo diferentes entidades.

Por outro lado, o mesmo autor destaca a existência de problemas de coordenação resultantes da separação vertical no setor ferroviário. Para RUS e CAMPOS (2006), as ferrovias requerem um elevado grau de coordenação entre a gestão da infraestrutura e a produção dos serviços de transporte, sendo a coordenação importante para que se possa garantir operações seguras e eficientes. Deste modo, nota-se que a separação vertical introduz um trade-off entre concorrência e coordenação, que é agravado pelo regime de "open access".

VAN DE VELDE et al. (2012) notam que a necessidade de coordenação varia conforme a situação da ferrovia, considerando-se aspectos como, por exemplo, a densidade de tráfego. Os custos de coordenação são menores em situações nas quais a interface entre o gestor da infraestrutura e o operador é simples e robusta, quando há excesso de capacidade na rede, quando todos os operadores desejam características similares na via, quando há reciprocidade nos direitos de acesso que limitam incentivos ao comportamento oportunista, e nos casos em que a maior parte dos ganhos resultantes da concorrência pode ser alcançada por meio da outorga de direitos a uma pequena parte da rede (GÓMEZ-IBAÑEZ, 2003).

Para KUROSAKI $(2008)^{93}$, os problemas de coordenação resultantes da separação vertical advêm de aumentos nos custos de transação entre a infraestrutura e a operação, em função da ampliação no número de contratos necessários; e de dificuldades introduzidas na

\footnotetext{
${ }^{92}$ KUROSAKI (2008, p.32)

${ }^{93}$ KUROSAKI (2008, p.36-39)
} 
identificação clara de responsabilidades das diferentes partes, na aquisição de conhecimento amplo sobre a operação e sobre medidas de segurança, na harmonização de diferentes tecnologias e otimização da operação ferroviária nas distintas malhas e no alcance do desenvolvimento técnico em todo o sistema ferroviário.

GÓMEZ-IBAÑEZ (2003) sugere que os beneficios da separação vertical aumentam em função de dois fatores: participação nos custos totais das atividades em que a concorrência é sustentável, de 60 a $80 \%$ no caso do transporte de cargas; e potencial para melhorias de produtividade, que é limitada no transporte ferroviário de forma geral.

O primeiro país que implementou a separação vertical no setor ferroviário foi a Suécia, a partir da aprovação da Nova Política de Transporte de 1988. Neste contexto, as atividades desempenhadas pela estatal Swedish State Railways (SJ) foram atribuídas a duas instituições distintas - a National Rail Administration - Banverket (BV) ${ }^{94}$, responsável pelo investimento e gestão da infraestrutura ferroviária e a nova SJ, operadora ferroviária - ao passo que novos operadores foram autorizados a entrar no mercado onde a estatal havia deixado de atuar. Em 1996, o mercado de prestação de serviços de transporte ferroviário de cargas foi desregulamentado - por meio de política de "open access" - para operadores nacionais e, a partir de 2007, também para operadores de outros países. Em 2010, a Suécia contava com quinze operadores ferroviários de carga, dos quais, oito privados. Dentre os operadores privados, quatro eram operadores maiores, com 20 ou mais empregados. Sem considerar a participação da operadora estatal MTAB, subsidiária da mineradora estatal, os operadores entrantes alcançaram, em 2010, 14\% de participação no mercado de transporte de cargas do país escandinavo. ${ }^{95}$ Conforme conclusão de relatório ${ }^{96}$ que analisa os quinze

\footnotetext{
${ }^{94}$ Após reestruturações, as atividades então desempenhadas pela Swedish Rail Administration estão desde 2010 a cargo da estatal Swedish Transport Administration (Trafikverket, http://www.trafikverket.se)

${ }^{95}$ Cf. VIERTH (2011). Percentual em TKU.
} 
primeiros anos de desregulamentação do transporte ferroviário de cargas na Suécia, procedimentos levam tempo para serem estabelecidos, da mesma forma que diferentes "stakeholders" demoram em encontrar seu (novo) papel no mercado.

Seguindo a experiência sueca, o Reino Unido aprovou em 1993 o 'Railways Act', que contemplou a separação entre a gestão da infraestrutura e a operação ferroviária. Em 1994, a empresa Railtrack passou a ser responsável pela gestão de todo o sistema ferroviário britânico. O caso britânico é emblemático na literatura, em função do fracasso da concessão da infraestrutura ferroviária durante a gestão da Railtrack. Conforme VAN DE VELDE et al. (2012), o fracasso se deveu às seguintes razões: i) exigência de renegociações, à medida que os requisitos eram alterados, levando a atrasos e incertezas ${ }^{97}$; ii) o papel do regulador em prevenir a discriminação de preços e preços de monopólio pelo uso da infraestrutura tornouse extremamente difícil ${ }^{98}$; iii) os operadores de passageiros com prazos contratuais com duração reduzida não podiam se comprometer com contratos de longo prazo envolvendo investimentos. Em 2002, a estatal 'Network Rail' 99 assumiu a malha da Railtrack. Atualmente em torno de 10 operadores ferroviários de cargas atuam no país.

A Diretiva 1991/440 da Comunidade Econômica Europeia - estabeleceu a política de livre acesso ao sistema ferroviário, com a promoção do acesso competitivo à via permanente por operadores não detentores de infraestrutura ferroviária e da separação comercial entre a exploração da infraestrutura e a prestação do serviço de transporte ferroviário. Em 2001, foi

\footnotetext{
${ }^{96}$ VIERTH (2011)

${ }^{97}$ O contrato com a Railtrack previa a manutenção e recuperação da infraestrutura, mas não a expansão substantiva de capacidade. Quando houve necessidade de expansão da capacidade, o processo de renegociação do aumento de capacidade bilateralmente entre a Railtrack e os operadores ferroviários não funcionou, resultando na necessidade de suporte governamental.

${ }^{98}$ Como exemplo, VAN DE VELDE et al.(2012, p.77) citam a situação em que o principal operador ferroviário conseguia utilizer seu poder de Mercado para negociar uma tarifa favorável que era vista como desvantajosa a outros operadores, mas era complicado concluir que se tratava de comportamento discriminatório.

${ }^{99}$ Em 2002, após passar por dificuldades financeiras, as operações da Railtrack foram assumidas pela estatal Network Rail.
} 
lançado um conjunto de disposições relativas ao acesso à infraestrutura ferroviária transeuropeia denominado 'Pacote de infraestrutura ferroviária' - 2001/12/CE 100 , 2001/13/CE ${ }^{101}$, 2001/14/CE ${ }^{102}$, com prazo de implementação pelos países membros até março de 2003. Em 2004, o segundo pacote - Diretiva 2004/51/CE - definiu a abertura à concorrência do tráfego de cargas na forma de "open access", estabelecendo 2007 como prazo limite de implementação e criou a Agência Ferroviária Europeia (ERA). Três anos depois, por meio do terceiro pacote, foi determinado que o prazo para os países promoverem a liberalização dos serviços de transporte internacional de passageiros seria janeiro de 2010 .

A Austrália também adotou, a partir de 1996, a separação vertical - na maior parte das ferrovias do país - e o regime "open access" para toda a rede interestadual e algumas malhas intraestaduais. ${ }^{103}$ Atualmente, por volta de 10 operadores de porte, que não exploram infraestrutura ferroviária, prestam serviços de transporte ferroviário no país. Outro aspecto que diferencia o caso australiano é a presença (não exclusiva) de empresas privadas como gestoras de infraestrutura ferroviária. Neste contexto, cabe destacar as empresas Brookfield Rail, John Holland e ARTC, que atuam exclusivamente na gestão dos trilhos, estando as duas primeiras sob controle privado. Outras características que se observam na Autrália é a convivência dos modelos verticalmente integrado e com separação vertical - tanto nas malhas ferroviárias interestaduais como nas intraestaduais - e a existência de diferentes marcos normativos nas jurisdições dos governos central e locais, que impactam diretamente na elevação dos custos transacionais.

\footnotetext{
100 Altera a Diretiva 1991/440/CE. Trata da liberalização do tráfego de cargas na denominada rede transeuropeia.

${ }^{101}$ Altera a Diretiva 1995/18/CE. Trata da harmonização técnica e operacional da interoperabilidade e segurança no transporte ferroviário de cargas, estabelecendo regras.

${ }^{102}$ Altera a Diretiva 1995/19/CE. Trata da alocação de capacidade de infraestrutura ferroviária, da tarifação de acesso à infraestrutura e da certificação em matéria de segurança. Disponível em: <http://eurlex.europa.eu/LexUriServ/LexUriServ.do?uri=OJ:L:2001:075:0029:0046:PT:PDF>
}

${ }^{103}$ Mais informações sobre o modelo australiano podem ser encontradas em MERKERT e HENSHER (2014). 


\section{FERROVIAS E CONCESSÕES FERROVIÁRIAS NO BRASIL}

\subsection{BREVE HISTÓRICO DA EVOLUÇÃO DAS FERROVIAS NO BRASIL}

A maior parte das ferrovias brasileiras foi construída entre a segunda metade do século XIX e a primeira metade do século XX e têm sua origem na exploração de recursos naturais para exportação. No período considerado, a economia nacional era fortemente dependente da exportação de café, e, em menor grau, da exportação de outros bens agrícolas açúcar, algodão e cacau.

Conforme classificação adotada por SILVA (1954), o desenvolvimento das ferrovias no Brasil, de $1854^{104}$ - com a inauguração dos primeiros $14,5 \mathrm{~km}$ de linha férrea da Estrada de Ferro Mauá (E. F. de Mauá) - a 1957, experimentou cinco períodos. Durante o primeiro período, de 1854 a 1870, foram construídos $744 \mathrm{~km}^{105}$ de linhas férreas em pequenos segmentos isolados nas províncias do Rio de Janeiro, Pernambuco, Bahia, São Paulo e Minas Gerais e na Capital do Império.

No segundo período, de 1871 a 1890 , foram acrescidos $9.228 \mathrm{~km}^{106}$ de ferrovias, com a ampliação das linhas construídas no período anterior expandindo-se na direção dos portos de Santos, Rio de Janeiro, Salvador e Recife, e construção de novas ferrovias nas províncias de Minas Gerais, Alagoas, Ceará, Rio Grande do Sul, Rio Grande do Norte, Paraíba, Paraná, Santa Catarina e Espírito Santo.

\footnotetext{
${ }^{104}$ A primeira ferrovia pública com tração a vapor foi a ligação de $61 \mathrm{~km}$ entre Stockton ao vale mineiro de Darlington, ao norte da Inglaterra, inaugurada em 27 de setembro de 1825.

${ }^{105}$ IBGE (1990)

${ }^{106}$ Idem.
} 
Os dois períodos que se seguiram, de 1891 a 1910 e de 1911 a 1930, foram de intensa atividade, com acréscimos superiores a $11 \mathrm{mil} \mathrm{km} \mathrm{de} \mathrm{ferrovias} \mathrm{em} \mathrm{cada} \mathrm{duração}{ }^{107}$. Foram ampliadas e/ou construídas novas linhas nos estados de São Paulo, Rio de Janeiro, Minas Gerais, Espírito Santo, Rio Grande do Sul, Paraná, Santa Catarina, Bahia, Alagoas, Pernambuco, Paraíba, Rio Grande do Norte, Maranhão, Piauí, Goiás e Pará, entre outros. Vale destacar o ano de 1910, quando foi registrado o recorde histórico de $2.084,5 \mathrm{~km}$ de ferrovias construídas, marca jamais superada no país, mesmo passado mais de um século. Ao final de 1930, a extensão ferroviária brasileira havia alcançado $32.478 \mathrm{~km}$.

De 1931 a 1957, foram construídos cerca de 5 mil $\mathrm{km}^{108}$ de linhas férreas. A partir de 1934, com o estabelecimento do Plano Geral Ferroviário, aprovado pelo Decreto $n^{0} 24.497$, de 29 de junho de 1934, o objetivo central do governo passou a ser a promoção da interconexão das ferrovias, com vistas à constituição de uma rede ferroviária nacional.

A Rede Ferroviária Federal S.A. (RFFSA) foi criada em março de 1957 com a finalidade de administrar, explorar, conservar, reequipar, ampliar e melhorar o tráfego das estradas de ferro da União a ela incorporadas, consolidando sob uma mesma administração a operação de 18 ferrovias, que totalizavam 37,4 mil km de extensão. Seguindo a mesma lógica, em 1971 foi criada a estatal FEPASA, por meio da unificação de cinco ferrovias do Estado de São Paulo.

A partir da segunda metade do século XX, ao mesmo tempo em que poucas ferrovias foram construídas, o governo procedeu à desativação de trechos e ramais considerados com baixa viabilidade econômica. Dentre as linhas construídas nas décadas mais recentes, destaca-se a Estrada de Ferro Carajás - inaugurada em fevereiro de 1985; a Ferronorte - cujo

\footnotetext{
${ }^{107}$ Nos períodos de 1891-1910 e 1911-1930, a extensão ferroviária brasileira foi ampliada em 11.352 km e $11.152 \mathrm{~km}$, respectivamente.

${ }^{108}$ Cf. IBGE (1990).
} 
primeiro trecho de $110 \mathrm{~km}$, entre Aparecida do Taboado e o terminal de Inocência, no Estado do Mato Grosso do Sul, foi inaugurado em maio de 1998 e atualmente se estende até Rondonópolis, no Estado do Mato Grosso; e a Ferrovia Norte-Sul - que teve o primeiro trecho de 215 km entre Açailândia e Porto Franco, no Estado do Maranhão, inaugurado em 1996 e apresenta obras concluídas até Anápolis, no Estado de Goiás.

De forma geral cabe destacar que, diferentemente do que se verifica nos Estados Unidos e Canadá, onde há mais de duas linhas férreas conectando dois destinos para a maior parte dos casos, no Brasil, assim como em muitos outros países, as ferrovias foram construídas em caráter de exclusividade, com uma única via interligando duas localidades (OECD, 2013). 


\subsection{A EXPERIÊNCIA BRASILEIRA EM CONCESSÕES FERROVIÁRIAS}

As concessões ferroviárias no Brasil podem ser analisadas considerando-se três ciclos distintos. O primeiro resgata a origem das primeiras ferrovias brasileiras na segunda metade do século XIX, financiadas, principalmente, com capital privado inglês. O segundo abarca as concessões promovidas, majoritariamente, na última década do século $\mathrm{XX}$, compreendendo a concessão da infraestrutura ferroviária (com ou sem construção de vias) e do serviço de transporte. Por fim, o último ciclo se refere às novas concessões anunciadas pelo governo federal, restrita à gestão da infraestrutura e ao controle de tráfego ferroviário, denominadas concessões horizontais.

\subsubsection{AS PRIMEIRAS CONCESSÕES FERROVIÁRIAS NO PAÍS}

O Brasil iniciou a implantação de sua malha ferroviária por meio do investimento privado. As ferrovias construídas durante o século XIX foram financiadas quase que exclusivamente com capital privado, ainda que em boa medida, suportadas por políticas de garantia de retorno ou subvenção quilométrica, renúncia fiscal, além de outros benefícios concedidos pelo governo.

O primeiro ciclo de concessões ferroviárias do país pode ser subdividido em dois períodos. O primeiro, de 1835 a 1852, compreendeu ensaios malogrados, que, por outro lado, contribuíram para preparar o terreno para as futuras realizações. Durante o segundo período (1852 a 1889), o Governo Imperial atraiu grande interesse privado para a construção de ferrovias, ao oferecer privilégios exclusivos, incluindo garantia de retorno aos empreendedores.

O interesse do governo brasileiro em contar com a participação da iniciativa privada no investimento em infraestrutura remonta à Lei promulgada pelo Governo Imperial em 29 
de agosto de 1828 - Lei José Clemente, por meio do qual estabelecia regras para a construção de obras que tivessem "por objeto promover a navegação dos rios, abrir canais ou construir estradas, pontes, calçadas ou aquedutos"109 por "empresários nacionais ou estrangeiros, associados em companhias ou isolados ${ }^{, 110}$.

O regime de contratação previsto na Lei de 1828 se assemelhava às concessões de serviço público precedidas de execução de obra pública previstas no artigo $2^{\circ}$, inciso III, da Lei que rege as concessões atuais - Lei ${ }^{\circ}$ 8.987/1995. Conforme pode ser observado através da leitura da norma de 1828, o Governo Imperial pretendia promover a implementação de projetos de infraestrutura sem envolver contraprestação pecuniária pública, no sentido da definição de concessão dada por MEDAUAR (2009) ${ }^{111}$ : "contrato por meio do qual a Administração Pública atribui a execução de serviços públicos ao particular, que deverá arcar com os riscos e receberá remuneração advinda dos usuários”.

Em seus artigos $6^{\circ}$ e $7^{\circ}$, o diploma legal de 1828 estabelecia que as datas para o início e término das obras, bem como a taxa de retorno sobre o capital investido, seriam expressas em contrato e que as tarifas seriam definidas com base nos orçamentos previstos para a execução das obras, caracterizando a regulação tarifária por taxa de retorno:

Art. $6^{\circ}$ No contracto com os emprezarios se expressará, além das mais condições que se convencionarem: Primeiro, o tempo, dentro do qual a obra deverá ser principiada, e acabada; segundo, o interesse, que os emprezarios devem perceber em compensação das suas despezas: e este poderá consistir no direito exclusivo da taxa de navegação dos rios, ou canaes, que se abrirem; na acquisição dos terrenos alagadiços, que, por beneficio de taes obras, se aproveitarem; não sendo de propriedade particular; ou no direito de cobrar e determinada taxa de uso da obra, que fizer o objecto da empreza por certo numero de annos, que se entender necessario para a amortização do capital empregado na obra, com os seus competentes interesses.

Art. $7^{\circ}$ A somma do capital, que pelo orçamento da despeza se calcular ser necessario para a construcção da obra, servirá de base para se fixar o quantitativo da taxa.

\footnotetext{
${ }^{109}$ Art. $1^{\circ}$ da Lei de 29 de agosto de 1828.

${ }^{110}$ Idem

${ }^{111}$ MEDAUAR (2009, p.216-217)
} 
A manutenção da infraestrutura "em perfeito estado de conservação"112 deveria ser garantida pelo concessionário, conforme previsto no artigo 12, durante todo período de concessão, o que indicava uma preocupação do governo pela regulação da qualidade, ainda que este aspecto ainda dependesse de regulamentação:

Art. 12. As obras depois de concluidas serão entretidas em estado de perfeita conservação á custa dos emprezarios todo o tempo, que durar o direito de cobrar a taxa de uso, e de passagens das mesmas obras.

O artigo $9^{\circ}$ da referida norma determinava que caso as empresas não cumprissem os projetos aprovados, nos prazos acordados, elas seriam penalizadas com multas estipuladas em contrato; podendo servir como um mecanismo para desincentivar a participação de empresários oportunistas:

Art. $9^{\circ}$. Os emprezarios serão obrigados a desempenhar, as emprezas, de que se encarregarem, segundo o plano approvado, e dentro do tempo, que se ajustar, debaixo da pena de pagarem uma multa, que será estipulada nos contractos.

Já o artigo 15 indicava que, nos casos em que não houvesse empresa interessada nos projetos promovidos pelo governo, que as obras seriam financiadas com recursos públicos, prevendo-se a cobrança de tarifa pela utilização da infraestrutura:

Art. 15. No caso de não apparecerem emprezarios com quem se contractem as referidas obras, serão estas feitas por conta dos rendimentos dos Conselhos, havendo-os, ou da Fazenda Publica; e para indemnização destas despezas, que se fizerem por conta da Fazenda Publica, se imporá o mesmo direito de uso, e de passagem, que deveria Ter lugar, se a obra se contractasse.

O primeiro intento de concessão de empreendimento ferroviário a empreendedor privado tinha como objeto a construção e operação, com exclusividade (regime de monopólio), de linhas férreas entre a capital do Império e às capitais das províncias de Minas

\footnotetext{
${ }^{112}$ O Decreto não qualificava o conceito de "estado de perfeita conservação" da infraestrutura.
} 
Gerais, Rio Grande do Sul e Bahia ${ }^{113}$. Por meio do Decreto ${ }^{\circ}$ 101, de 31 de outubro de 1835 - denominado "Decreto de Feijó", foram estabelecidas regras a serem aplicadas na concessão pelo prazo de 40 anos da ferrovia, dentre as quais: as tarifas-teto a serem adotadas para o transporte de carga e de passageiros ${ }^{114}$; e a obrigação de se construir, no mínimo, 33 km (5 léguas) de linhas por ano. Ao mesmo tempo, o Decreto no 101/1835 estipulava um conjunto de incentivos ao investidor ${ }^{115}$ :

- benefícios fiscais ${ }^{116}$ - suspensão, pelo prazo de cinco anos, do pagamento de imposto de importação na aquisição de máquinas, barcos a vapor, instrumentos ou outros artefatos de ferro ou metal, desde que devidamente comprovados.

- cessão de terras ${ }^{117}$ - cessão gratuita de terras devolutas e garantia de desapropriação compulsória de bens particulares; neste caso, o proprietário poderia apenas contestar o valor a ser recebido a título de indenização.

- possibilidade de prorrogação do contrato de concessão por mais $40 \operatorname{anos}^{118}$. Caso o concessionário não desejasse a renovação, o governo o compensaria pelo investimento realizado.

\footnotetext{
${ }^{113}$ As três províncias retratavam a representação dos autores do projeto apresentado na Câmara na sessão de 03 de outubro de 1835: Deputado Pereira de Vasconcelos (Minas Gerais); Manuel Paranhos da Silva (Rio Grande do Sul) e José Floriano de Figueiredo Rocha (Bahia).

${ }^{114}$ Observa-se aqui a preocupação pela modicidade tarifária.

${ }^{115}$ Art. $3^{\circ}$ do Decreto no 101/1835 - "O Governo poderá conceder a estas Companhias os privilegios concedidos á do Rio Doce nos arts. $5^{\circ}, 6^{\circ}, 8^{\circ}, 9^{\circ}$ e 13 , do Decreto de 17 de Setembro do corrente anno, em tudo quanto fôr applicaveI."

${ }^{116}$ Art. $6^{\circ}$ do Decreto n ${ }^{\circ} 24 / 1835$ - "Todas as machinas, barcos de vapor, instrumentos, ou outros artefact, os de ferro ou qualquer metal, importados para o serviço da Companhia, serão isentas de quaesquer direitos de importação por espaço dos primeiros cinco annos, ficando a Companhia privada deste privilegio, logo que por sentença se prove ter havido abuso da sua parte."

${ }^{117}$ Art. $8^{\circ}$ do Decreto n ${ }^{\circ} 24 / 1835$ - "Os terrenos, de que a Companhia houver de necessitar para a construcção de estradas, pontes, caes, comportas, canaes, diques ou reprezas, se forem devolutos, ser-lhe-hão cedidos gratuitamentes, se de propriedade particular, serão prévia e definitivamente avaliados por arbitros, e o seu importe entregue por ella aos proprietarios, ou depositado em juizo no caso de que elle recusem recebe-lo; não devendo por pretexto algum ser a Companhia estorvada em seus trabalhos, salvo aos proprietarios o recurso para o Tribunal competente, sómente no que respeita á boa ou má avaliação.”
} 
- liberdade para fixar tarifas ${ }^{119}$, limitadas a valores teto.

Após a publicação do Decreto $\mathrm{n}^{\circ}$ 101/1835, o Governo, sob a regência do Padre Diogo Feijó, enviou emissários do Brasil ao exterior com a missão de atrair investidores para a construção de linhas férreas no país. No entanto, conforme observa CORREA FILHO (1954), “não bastaria o auxílio prometido, sobremaneira exíguo, para despertar o entusiasmo dos capitalistas, no início de uma indústria mal conhecida”. As condições oferecidas pelo governo não despertaram o interesse privado por serem consideradas insuficientes, conforme apurado pelo Marquês de Barbacena em uma de suas viagens à Europa (CORREA FILHO, 1954). Ao mesmo tempo, cabe recordar que o Brasil se encontrava consternado por grande conturbação política e social, que marcaram todo o período regencial (1831-1840).

Dezessete anos mais tarde, o Governo Imperial do Segundo Reinado promulgou o Decreto Legislativo $n^{\circ} 641^{120}$, de 26 de junho de 1852 , que resgatava o projeto de 1835 , com duas modificações de traçado: i) excluiu a ligação entre a Capital Imperial e Salvador; e ii) incluiu o tramo ferroviário entre o município da Corte e a província de São Paulo. O Governo promovia, ainda, uma série de aperfeiçoamentos ao modelo com vistas a incentivar a participação privada na construção da Estrada de Ferro de D. Pedro II (denominada E. F. Central do Brasil a partir de $1889^{121}$ ), dentre os quais:

- ampliação no prazo de concessão, previsto originalmente em 40 anos, para um período limitado a 90 anos;

\footnotetext{
${ }^{118}$ Art. $9^{\circ}$ do Decreto n ${ }^{\circ}$ 24/1835 - "As taxas, que a Companhia estabelecer em seu beneficio pelo transito das estradas, pontes, canaes, ou pela navegação que lhe é privativa, serão consideradas interesse do capital nos primeiros 40 annos, reservando-se á Nação, passado esse prazo, o direito de remir as obras pelo valor, e modo que fôr estabelecido a juizo de arbitros, ou de prorogar o privilegio por mais outros 40 annos, findos os quaes, sem indemnisação alguma, obrigada a Companhia e entrega-las em bom estado."

${ }^{119}$ Art. 13 do Decreto n’ 24/1835 - "É livre á Companhia fixar o frete, pedagio, ou direito de passagem que ella julgar conveniente, podendo fazer um regulamento para a navegação geral do Rio Doce, e seus confluentes, o qual, depois de approvado pelo Governo, não será alterado."

${ }^{120}$ Decreto n ${ }^{\circ}$ 641/1852, denominado "Lei de Garantia de Juros".

${ }^{121}$ Cf. Aviso n ${ }^{\circ}$ 143, de 22/11/1852
} 
- possibilidade de utilização de madeiras e outros materiais disponíveis nos terrenos devolutos e nacionais para a construção da via permanente;

- isenção de imposto de importação sobre trilhos, máquinas, instrumentos e outros objetos destinados à construção da via;

- estabelecimento de zona privilegiada de $33 \mathrm{~km}$ (5 léguas) para cada lado do eixo da linha;

- isenção, por período determinado, de imposto de importação sobre o carvão consumido na operação das locomotivas a vapor.

Adicionalmente a esses benefícios, o Governo Imperial reviu determinação anterior, que previa a inexistência de contraprestação pecuniária pública, e passava a oferecer garantia de retorno anual, por período determinado ${ }^{122}$, de até $5 \%$ sobre o capital empregado na construção da linha férrea ${ }^{123}$. Esta mudança estava alinhada com o que se observava à época em outros países - como Rússia, Suécia, Índia, Peru e Argentina, que já ofereciam a garantia de juros como mecanismo para atrair capital para o financiamento de projetos ferroviários.

Apesar de o conjunto de vantagens oferecido pelo governo ter atraído interesse de uma firma inglesa, os empreendedores não tiveram êxito em levar o projeto adiante e rescindiram o contrato de concessão em janeiro de 1855 (CORREA FILHO, 1954). Como consequência, por meio do Decreto ${ }^{\circ} 1.599$ de 09 de maio de $1855^{124}$, o governo deliberou pela assunção de responsabilidade financeira das obras de construção da ferrovia e autorizou

\footnotetext{
${ }^{122}$ Cf. CORREA FILHO (1954), "a garantia de juros perduraria enquanto a exploração dos serviços subvencionados rendesse menos de $8 \%$ do capital invertido, que não estava sujeito a limitação alguma“. "Quando a renda anual excedesse o limite fixado, dar-se-ia o reembolso dos adiantamentos feitos pelo Tesouro."

${ }^{123} \mathrm{O}$ Decreto $\mathrm{n}^{\mathrm{o}} 641 / 1852$ previa que logo que a empresa passasse a perceber pelo menos $8 \%$ em dividendos, ela deveria ressarcir os valores recebidos a título de garantia de juros.

${ }^{124}$ Por meio do Decreto $n^{\text {o }} 1.599 / 1855$, o governo autoriza a constituição de uma empresa pública para a construção da E. F. de Dom Pedro II, financiada por meio de subscrição de ações.
} 
a constituição de empresa pública para este fim: a Companhia da Estrada de Ferro de D. Pedro II.

Cabe assinalar que, conforme indicado em seu art. $2^{\circ}$, o Decreto Legislativo $\mathrm{n}^{\circ}$ 641/1852 representou o marco jurídico inicial das concessões de projetos ferroviários no país:

Art. $2^{\circ}$ Se apparecerem Companhias que se proponhão a construir caminhos de ferro em quaesquer outros pontos do Imperio, poderá o Governo igualmente contractar com ellas sobre as mesmas bases declaradas no Artigo antecedente. $[\ldots]$.

Não obstante o claro interesse do Governo Imperial de contar com a participação privada nos projetos de infraestrutura, particularmente de ferrovias, observa-se que certos aspectos relativos à condução desses empreendimentos só viriam a ser regulamentados alguns anos mais tarde. Fortalece essa afirmação o fato de que os procedimentos relativos à desapropriação de prédios e terrenos para a construção de estradas de ferro no país tenham sido aprovados em 20 de outubro de 1855 (vide Decreto $\mathrm{n}^{\circ}$ 1.664/1855).

Da mesma forma, a fiscalização da segurança, conservação e polícia das estradas de ferro, prevista no $§ 14$ do Art. $1^{\circ}$ do Decreto Legislativo $n^{\circ} 641 / 1852^{125}$, levaria, ainda, cinco anos para ser regulamentada, sendo estabelecida pelo Decreto $\mathrm{n}^{\mathrm{o}} 1.930$, de 26 de abril de 1857, ampliada pelo Decreto $\mathrm{n}^{\circ} 2.913$, de 23 de abril de 1862. Chama atenção o fato de esta norma ter sido aprovada três anos após a inauguração da primeira ferrovia do país e depois de outorgada a concessão de outros cinco projetos ferroviários.

Outro aspecto que se evidenciava era o açodamento do governo na execução de projetos, ilustrado por comentário de Christiano Benedicto Ottoni - considerado o "pai das

\footnotetext{
${ }^{125}$ Art. $1^{\circ}$ do Decreto n ${ }^{\circ}$ 641/1852: "§14 Por meio dos necessarios Regulamentos, e de intelligencia com a Companhia, providenciará o Governo sobre os meios de fiscalisação, segurança e policia do caminho de ferro, bem como estatuirá quaesquer outras medidas relativas á construcção, uso, conservação e costeio do caminho de ferro, podendo impor aos infractores penas de multa até duzentos mil réis, e de prisão até tres mezes, e solicitando do Corpo Legislativo providencias ácerca de penas mais graves e proporcionadas aos crimes que possão affectar a sorte da empresa, as garantias do publico, e os interesses do Estado."
} 
estradas de ferro do Brasil" (apud CORREA FILHO, 1954), ao referir-se ao contrato referente à construção da Estrada de Ferro de D. Pedro II:

A celebração deste contrato [...] revela a intenção do ilustre diplomata que o firmou, de prestar serviço ao seu país, apressando a execução da estrada de ferro D. Pedro II; mas não se baseando os ajustes em estudos técnicos suficientes e sim em planos que só contêm o resultado de alguns reconhecimentos preliminares do terreno, tornou-se forçoso conceder ao empresário faculdades amplíssimas $e$ perigosas, que, a não acharem corretivo com outras estipulações, tornariam difícil toda fiscalização.

Entre 1854 e 1873 foi construído um total de $1.129 \mathrm{~km}$ de ferrovias, com expansão média anual de 56,4 km.

A partir do ano de 1873, o parlamento brasileiro dava novo impulso no fomento à construção de ferrovias no país, por meio da aprovação de dois Decretos Legislativos complementares ao Decreto de 1852. O primeiro deles, o Decreto Legislativo $n^{\circ}$ 2.237/1873, ampliou os benefícios previstos no Decreto Legislativo $n^{\circ}$ 641/1852 relativos à isenção de imposto de importação, antes restrito à aquisição de insumos e equipamentos associados à construção da via permanente, passando a abranger todo material utilizado na operação ferroviária.

O segundo dispositivo se refere ao Decreto Legislativo $\mathrm{n}^{\circ} 2.450 / 1873$, por meio do qual se autorizava a elevação da garantia de juros do governo geral em até $7 \%$ do capital efetivamente empregado na construção da ferrovia, que previa a possibilidade de concessão de subvenção quilométrica como alternativa à garantia de juros, e estabelecia o prazo desses benefícios para 30 anos. Ademais, nos casos em que houvesse garantia provincial, o governo imperial passava a afiançar essas garantias.

O Decreto Legislativo $n^{\circ}$ 2.450/1873 estabelecia, ainda, duas limitações à concessão de subvenção quilométrica ou garantia de juros: 
- Poderiam ser concedidas apenas para estradas de ferro que servissem de comunicação entre os centros produtores e de exportação, limitada a uma ferrovia por província.

- O total em subvenção quilométrica ou garantia de juros concedido pelo governo não poderia exceder montante ${ }^{126}$ estabelecido pelo mesmo Decreto.

Em 28 de fevereiro de 1874, o governo imperial aprovou, por meio do Decreto $\mathrm{n}^{\circ}$ 5.561, o assim denominado 'Regulamento para a boa execução dos Decretos Legislativos 641/1852 e 2.450/1873". Dentre outras disposições, o Decreto $n^{\circ}$ 5.561/1874 normatizou condições de contratação, execução e reversão das concessões contratadas pelo Governo Imperial, além de ampliar benefícios aos concessionários, ao estabelecer:

- a concorrência como modalidade de contratação de concessões ferroviárias, com o estabelecimento das condições gerais a ela associadas. Deste modo, observa-se que o governo passava a regular a entrada de empresas no setor, favorecendo, ainda, a redução dos riscos associados ao comportamento oportunista de seleção adversa.

- o conteúdo do projeto definitivo a ser aprovado pelo governo, previamente ao início das obras.

- a obrigatoriedade de as companhias ferroviárias, bem como seus representantes legais, possuírem domicílio legal no Império.

- a reversão para o Estado, sem direito à indenização, da ferrovia, bem como do respectivo material rodante, ao término do prazo de concessão.

- a possibilidade de resgate da ferrovia pelo governo passados 15 anos do prazo de concessão, com direito à indenização. ${ }^{127}$ Com isso, observa-se que o governo passava a regular o comportamento oportunístico do próprio concedente.

\footnotetext{
${ }^{126}$ Fixado em 100.000:000,\$, conforme indicado no $\$ 4^{\circ}$ do Decreto n ${ }^{\circ} 2.450 / 1873$. Ao custo médio de 25:000,\$ por km de via férrea, considerado por Rebouças (1874), seria possível construir 4 mil km de ferrovias.
} 
- a possibilidade de o governo exigir a redução de tarifas quando os dividendos excedessem $12 \%$ durante dois anos consecutivos. ${ }^{128}$ Neste caso, evidencia-se, mais uma vez, a utilização da regulação tarifária por taxa de retorno.

- preferência para lavra de minas na zona privilegiada.

- preferência para aquisição de terrenos devolutos existentes à margem da estrada de ferro.

Quatro anos mais tarde, o marco legal relativo à concessão de ferrovias é novamente aprimorado, com a aprovação do Decreto n ${ }^{\circ}$ 6.995, de 10 de agosto de 1878. Neste contexto, foram promovidas as seguintes modificações, dentre outras:

- redução da zona privilegiada de $33 \mathrm{~km}$ para $20 \mathrm{~km}$ de cada lado do eixo da ferrovia.

- estabelecimento de condições de caducidade do privilégio, da fiança, ou da garantia de juros e mais favores.

- ampliação do tempo mínimo a partir do qual o governo poderia resgatar a ferrovia para 30 anos após a conclusão das obras de construção.

- instituição de mecanismo de arbitragem para solução de conflitos contratuais entre o governo e as companhias ferroviárias.

- obrigatoriedade de partilha do excesso de dividendos, em partes iguais entre o governo e as companhias, logo que passassem a perceber dividendos superiores a $8 \%$, cessando essa divisão logo que fossem embolsados ao Estado os juros pagos por este.

Finalmente, com a aprovação em 29 de dezembro de 1880 dos Decretos $n^{\circ} 7.959$ e $n^{\circ}$ 7.960, se completava o arcabouço jurídico das concessões ferroviárias do período imperial. As principais alterações previstas nestes dispositivos compreendem os seguintes aspectos:

\footnotetext{
${ }^{127}$ Regulamentação do $\$ 13$, art. $1^{\circ}$ do Decreto nº 641, de 26/06/1852.

${ }^{128}$ Regulamentação do $\S 8^{\circ}$, art. $1^{\circ}$ do Decreto n ${ }^{\circ} 641$, de 26/06/1852.
} 
- Condições para inibir o uso indevido do benefício de preferência para aquisição de terrenos devolutos existentes à margem da estrada de ferro ${ }^{129}$. Observa-se, neste dispositivo, que o governo passava a regular o possível comportamento oportunista de empresários que poderiam ingressar no setor ferroviário, com real interesse em lucrar com a aquisição privilegiada de terrenos devolutos.

- Condições específicas relativas às subvenções quilométricas, fianças ou garantias de juros.

- Previsão de revisão tarifária, no mínimo, a cada 5 anos.

Com efeito, as condições atrativas oferecidas pelo Governo Imperial produziram no país um verdadeiro surto ferroviário. Entre 1874 e 1889 foram incluídos 8.454 km de linhas férreas à malha nacional, com média anual de 528,4 km de ferrovias construídas.

Apesar do êxito no fomento à expansão de ferrovias no Brasil por meio de parcerias com o setor privado, CORREA FILHO (1954) conclui que a política de incentivos à construção de ferrovias adotada pelo Governo Imperial trouxe algumas consequências negativas ao sistema ferroviário do país que perduram até hoje, tais como:

- Estradas de ferro localizadas no país de forma dispersa, isolada e desarticulada;

- Ferrovias com especificações técnicas não padronizadas, com grande diversidade de bitolas, que dificultam a interoperabilidade entre as malhas;

- Traçados das estradas de ferro excessivamente sinuosos - por muitos denominadas ferrovias cata-café ${ }^{130}$ - e extensos.

Entre as explicações para estes resultados, cabe apontar alguns aspectos associados ao modelo adotado. Como observado por SAES (1986 apud STADUTO, DA ROCHA JR e DE FREITAS, 2003), muitos empresários que ingressaram no setor ferroviário eram de origem

\footnotetext{
${ }^{129}$ Cláusula I, $6^{\circ}$ do Decreto no 7.959 , de 29/12/1880.

${ }^{130}$ Expressão cunhada por DE MATOS (1974).
} 
“mercantil” e esperavam lucros imediatos provenientes do investimento no setor. É possível que esta condição fosse consequência da política de garantia de juros estabelecida pelo Governo Imperial, que adotava taxas superiores àquelas oferecidos por outros países. ${ }^{131}$ Pode-se sugerir que esta situação se caracteriza como um problema de seleção adversa, pois o modelo não foi capaz de introduzir regras que conduzissem à seleção de empreendedores com o perfil adequado.

Entende-se, da mesma forma, que as ferrovias eram desarticuladas, pois não foram criados incentivos para a sua integração. Muitas delas foram construídas em torno da economia cafeeira, com o objetivo central de promover o escoamento da produção pelos portos do país, sendo as ferrovias parte da cadeia produtiva do grão.

Outro aspecto que merece destaque é o fato de que somente em 1892 foi criada a Inspetoria Geral de Estradas de Ferro $^{132}$, com a atribuição de fiscalizar a construção e a operação das ferrovias no país. Durante todo o Governo Imperial, as concessões foram fiscalizadas de forma precária, sob a responsabilidade de um engenheiro fiscal designado pelo governo $^{133}$.

O primeiro ciclo de concessões considerado neste documento se encerra com a Proclamação da República. Cabe esclarecer que o governo não deixou de promover concessões a partir de 1889, da mesma forma que não eliminou as políticas de garantia de juros ou subvenção quilométrica. Sem embargo, inicia-se um período de crescente intervenção estatal, com a encampação das ferrovias que vinham enfrentando dificuldades

\footnotetext{
${ }^{131}$ Apenas na Argentina, as taxas de juros garantidas pelo governo superavam aquelas oferecidas pelo Governo brasileiro.

${ }^{132}$ Cf. Decreto no 1.164 , de 09/12/1892.

${ }^{133}$ Cf. art. 12 do Decreto n 6.995, de 10/08/1878, a "fiscalisação da estrada e do serviço será incumbida a um Engenheiro fiscal e seus ajudantes, nomeados pelo Governo, e por elle pagos; e o exame, bem como o ajuste de contas de receita e despeza para o pagamento dos juros afiançados ou garantidos, á uma commissão composta do Engenheiro fiscal e por elle presidida ou por quem suas vezes fizer, de um agente da companhia e de mais um empregado, designado pelo Governo ou a Presidencia da provincia."
} 
financeiras. Neste contexto, o governo apropriava-se das linhas, enquanto a operação daquelas que tinham melhor potencial de retorno financeiro era transferida a empresas privadas por meio de contratos de arrendamento. Como resultado, enquanto até 1889 o governo detinha a propriedade de apenas um terço das ferrovias, já em 1914 a situação se invertia, com as empresas sendo proprietárias de apenas 39\% das linhas.

Conforme NASH (2011) ${ }^{134}$, os mencionados problemas financeiros foram enfrentados por diversas ferrovias ao redor do mundo, e se agravaram com a crescente competição promovida pelo transporte rodoviário, principalmente, após a Primeira Guerra Mundial.

${ }^{134}$ NASH (2011, p.763) 


\subsubsection{AS CONCESSÕES FERROVIÁRIAS ATUAIS}

O segundo ciclo de concessões ferroviárias considerado neste trabalho envolve concessões com contratos vigentes e outorgadas, majoritariamente, no último quinquênio do século XX. Deste conjunto, podem ser considerados dois agrupamentos. O primeiro grupo, apresentado na Tabela 5, abrange as ferrovias que integravam a Rede Ferroviária Federal S.A. (RFFSA), enquanto o segundo grupo, constante da Tabela 6, inclui as demais ferrovias em operação no país. Conforme se observa, as ferrovias brasileiras são, em boa parte, controladas por clientes cativos do modal dos setores de mineração e siderurgia.

Em 1992, foi publicado o Decreto n ${ }^{\circ} 473$, por meio do qual a RFFSA foi incluída no Programa Nacional de Desestatização (PND). A inclusão da RFFSA no PND foi o primeiro passo formal do processo que culminou na restruturação do setor ferroviário e a transferência para o setor privado da exploração e desenvolvimento do serviço público de transporte ferroviário de carga no país. Com a aprovação do Conselho Nacional de Desestatização (CND), as ferrovias operadas pela RFFSA foram concedidas agrupadas em seis malhas regionais: Oeste ${ }^{135}$, Centro-Leste ${ }^{136}$, Sudeste $^{137}$, Tereza Cristina ${ }^{138}$, Sul $^{139}$ e Nordeste ${ }^{140}$. Os

\footnotetext{
${ }^{135}$ Edital BNDES no PND/A-05/95/RFFSA, disponível em: $<$ http://pesquisa.in.gov.br/imprensa/jsp/visualiza/index.jsp?data=30/11/1995\&jornal=3\&pagina=75\&totalArqui vos=168>. Ágio de 22,3\% sobre o preço mínimo (R \$ 51,0 milhões) estabelecido no edital.

${ }^{136}$ Edital BNDES n ${ }^{\circ}$ PND/A-03/96/RFFSA, disponível em: $<$ http://www.antt.gov.br/html/objects/_downloadblob.php?cod_blob=360>. Pelo preço mínimo (R \$ 316,9 milhões) estabelecido no edital.

${ }^{137}$ Edital BNDES n ${ }^{\circ}$ PND/A-05/96/RFFSA, disponível em: $<\underline{\text { http://pesquisa.in.gov.br/imprensa/jsp/visualiza/index.jsp?data=11/07/1996\&jornal=3\&pagina=76\&totalArqui }}$ vos=124>. Pelo preço mínimo (R \$ 888,9 milhões) estabelecido no edital.

${ }^{138}$ Edital BNDES no PND/A-07/96/RFFSA, disponível em: $<\underline{\text { http://pesquisa.in.gov.br/imprensa/jsp/visualiza/index.jsp?data=08/10/1996\&jornal=3\&pagina=49\&totalArqui }}$ vos=104>. Ágio de 11,3\% sobre o preço mínimo (R\$16,6 milhões) estabelecido no edital.

${ }^{139}$ Edital BNDES n ${ }^{\circ}$ PND/A-08/96/RFFSA, disponível em: $<$ http://pesquisa.in.gov.br/imprensa/jsp/visualiza/index.jsp?data=21/10/1996\&jornal=3\&pagina=67\&totalArqui

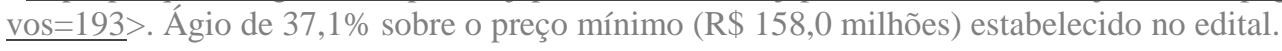


vencedores dos leilões, realizados entre março de 1996 e julho de 1997, passaram a operar as respectivas ferrovias em datas compreendidas entre julho de 1996 e janeiro de 1998.

Tabela 5 - Grupo I - Concessões das malhas da antiga RFFSA - 2013 (extensão total: $24.671 \mathrm{~km}$ )

\begin{tabular}{|c|c|c|c|c|c|c|c|c|}
\hline Malha & Controlador & $\begin{array}{l}\text { Concession } \\
\text { ária - } \\
\text { Denominaç } \\
\text { ão atual }\end{array}$ & $\begin{array}{c}\text { Concession } \\
\text { ária - } \\
\text { Denominaç } \\
\text { ão início da } \\
\text { concessão }\end{array}$ & $\begin{array}{c}\text { Data de } \\
\text { lançament } \\
\text { o do edital } \\
\text {-Data do } \\
\text { leilão }\end{array}$ & Outorga & $\begin{array}{l}\text { Início da } \\
\text { operação }\end{array}$ & $\begin{array}{l}\text { Prazo de } \\
\text { concessão }\end{array}$ & $\begin{array}{c}\text { Extensão } \\
\text { em } 2013 \\
(\mathbf{k m})\end{array}$ \\
\hline Oeste & ALL & $\begin{array}{l}\text { ALLMO - } \\
\text { América } \\
\text { Latina } \\
\text { Logística } \\
\text { Malha } \\
\text { Oeste S.A. }\end{array}$ & $\begin{array}{l}\text { NOVOEST } \\
\text { E - Ferrovia } \\
\text { Novoeste S. } \\
\text { A. }\end{array}$ & $\begin{array}{c}29 / 11 / 1995 \\
- \\
05 / 03 / 1996\end{array}$ & $\underline{26 / 06 / 1996}$ & $01 / 07 / 1996$ & $\begin{array}{c}30 \text { anos, a partir de } \\
01 / 07 / 1996\end{array}$ & 1.945 \\
\hline $\begin{array}{l}\text { Centro- } \\
\text { Leste }\end{array}$ & $\begin{array}{l}\text { VLI: VALE } \\
(64,1 \%), \\
\text { Mitsui }(20 \%) \\
\text { e FI-FGTS } \\
(15,9 \%)\end{array}$ & $\begin{array}{l}\text { FCA - } \\
\text { Ferrovia } \\
\text { Centro- } \\
\text { Atlântica } \\
\text { S.A. }\end{array}$ & $\begin{array}{l}\text { FCA - } \\
\text { Ferrovia } \\
\text { Centro- } \\
\text { Atlântica } \\
\text { S.A. }\end{array}$ & $\begin{array}{c}28 / 03 / 1996 \\
- \\
14 / 06 / 1996\end{array}$ & $\underline{26 / 08 / 1996}$ & 01/09/1996 & $\begin{array}{c}30 \text { ano, a partir de } \\
01 / 09 / 1996\end{array}$ & 7.427 \\
\hline Sudeste & $\begin{array}{l}\text { MBR }(20,0 \% \\
\text { — VALE: } \\
98,3 \%), \text { CSN } \\
(27,83 \%), \\
\text { USIMINAS } \\
(19,92 \%), \\
\text { VALE } \\
(19,26 \%) \text { e } \\
\text { GERDAU } \\
(2,37 \%)\end{array}$ & $\begin{array}{l}\text { MRS } \\
\text { Logística } \\
\text { S.A. }\end{array}$ & $\begin{array}{l}\text { MRS } \\
\text { Logística } \\
\text { S.A. }\end{array}$ & $\begin{array}{c}11 / 07 / 1996 \\
- \\
20 / 09 / 1996\end{array}$ & $\underline{26 / 11 / 1996}$ & 01/12/1996 & $\begin{array}{c}30 \text { anos, a partir de } \\
01 / 12 / 1996\end{array}$ & 1.674 \\
\hline $\begin{array}{l}\text { Tereza } \\
\text { Cristina }\end{array}$ & FTC & $\begin{array}{l}\text { FTC - } \\
\text { Ferrovia } \\
\text { Tereza } \\
\text { Cristina } \\
\text { S.A. }\end{array}$ & $\begin{array}{l}\text { FTC - } \\
\text { Ferrovia } \\
\text { Tereza } \\
\text { Cristina } \\
\text { S.A. }\end{array}$ & $\begin{array}{c}08 / 10 / 1996 \\
- \\
26 / 11 / 1996\end{array}$ & $\underline{24 / 01 / 1997}$ & 01/02/1997 & $\begin{array}{c}30 \text { anos, a partir de } \\
01 / 02 / 1997\end{array}$ & 164 \\
\hline Sul & ALL & $\begin{array}{l}\text { ALLMS - } \\
\text { América } \\
\text { Latina } \\
\text { Logística } \\
\text { Malha Sul } \\
\text { S.A. }\end{array}$ & $\begin{array}{l}\text { Empresa } \\
\text { Ferrovia } \\
\text { Sul- } \\
\text { Atlântico } \\
\text { S.A. }\end{array}$ & $\begin{array}{c}21 / 10 / 1996 \\
- \\
13 / 12 / 1996\end{array}$ & $\underline{21 / 02 / 1997}$ & 01/03/1997 & $\begin{array}{c}30 \text { anos, a partir de } \\
01 / 03 / 1997\end{array}$ & 7.265 \\
\hline $\begin{array}{l}\text { Nordest } \\
\text { e }\end{array}$ & $\mathrm{CSN}$ & $\begin{array}{l}\text { TLSA - } \\
\text { Transnordes } \\
\text { tina } \\
\text { Logística } \\
\text { S.A. }\end{array}$ & $\begin{array}{l}\text { CFN - } \\
\text { Companhia } \\
\text { Ferroviária } \\
\text { do Nordeste } \\
\text { S.A. }\end{array}$ & $\begin{array}{c}02 / 05 / 1997 \\
- \\
18 / 07 / 1997\end{array}$ & $\underline{30 / 12 / 1997}$ & 01/01/1998 & $\begin{array}{c}30 \text { anos, a partir de } \\
01 / 01 / 1998\end{array}$ & 4.207 \\
\hline Paulista & ALL & $\begin{array}{l}\text { ALLMP - } \\
\text { América } \\
\text { Latina } \\
\text { Logística } \\
\text { Malha } \\
\text { Paulista } \\
\text { S.A. }\end{array}$ & $\begin{array}{l}\text { FERROBA } \\
\text { N - Ferrovia } \\
\text { Bandeirante } \\
\text { s S.A. }\end{array}$ & $\begin{array}{c}23 / 07 / 1998 \\
- \\
10 / 11 / 1998\end{array}$ & $\underline{22 / 12 / 1998}$ & 01/01/1999 & $\begin{array}{c}30 \text { anos, a partir de } \\
01 / 01 / 1999\end{array}$ & 1.989 \\
\hline
\end{tabular}

Fonte: ANTT (2014e)

${ }^{140}$ Edital BNDES no PND/A-02/97/RFFSA, disponível em:

$<$ http://pesquisa.in.gov.br/imprensa/jsp/visualiza/index.jsp?data=02/05/1997\&jornal=3\&pagina=49\&totalArqui

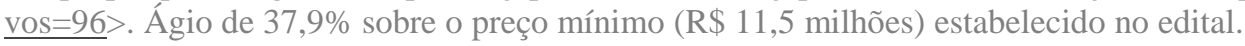


No caso da Malha Paulista, o processo envolveu uma etapa adicional realizada em janeiro de 1998: a federalização da malha - até então controlada pela Ferrovia Paulista S.A. (FEPASA), e sua incorporação à RFFSA. Em novembro do mesmo ano, a Malha Paulista foi leiloada $^{141}$, com a operação privada iniciada a partir de janeiro de 1999 . Desta forma, foi concluído o processo de transferência das ferrovias da RFFSA para o controle privado.

Conforme dados da Agência Nacional de Transportes Terrestres (ANTT, 2014c), as malhas da antiga RFFSA totalizavam, em 2013, $24.671 \mathrm{~km}$, correspondente a $86,6 \%$ da extensão total de linhas férreas em operação no Brasil. No mesmo ano, a produção de transporte realizado pelas concessionárias destas ferrovias foi de $101,2^{142}$ bilhões de TKU (34,0\% do total global das ferrovias do país ${ }^{143}$, tendo destaque a MRS ${ }^{144}$, responsável por $60,7 \%$ deste total ${ }^{145}$.

O segundo agrupamento, apresentado na Tabela 6, refere-se às outras oito ferrovias que operam no país que não integravam as linhas da RFFSA. Em 2013, elas totalizavam 3.815,4 km de extensão, correspondente a 13,4\% das linhas em operação. No mesmo ano, estas ferrovias foram responsáveis pela produção de 196,1 bilhões de toneladas, equivalente a $66,0 \%$ da produção agregada das ferrovias brasileiras ${ }^{146}$.

Neste grupo encontra-se a concessão da Estrada de Ferro Carajás (EFC), re-outorgada à Companhia Vale do Rio Doce S.A. (CVRD) - atual Vale S.A. - quando de sua privatização

\footnotetext{
${ }^{141}$ Edital BNDES nº PND-02/98/RFFSA, disponível em: <pesquisa.in.gov.br/imprensa/jsp/visualiza/index.jsp?data=23/07/1998\&jornal=3\&pagina=127\&totalArquivos= 184>. Ágio de 6,4\% sobre o preço mínimo (R\$230,4 milhões) estabelecido no edital.

142 Observa-se que excluindo-se a participação dos minerais, o total da produção destas ferrovias se reduz para 43,8 bilhões de TKU.

${ }^{143}$ É notável a distorção do sistema, com apenas 34,0\% da carga sendo transportada por ferrovias que correspondem a $86,6 \%$ da extensão total da malha brasileira.

${ }^{144}$ A MRS é uma transportadora de minério de ferro, originado do quadrilátero ferrífero de Minas Gerais e destinado à Companhia Siderúrgica Nacional (CSN) e ao Terminal de Guaíba.

${ }^{145}$ Contrasta com o fato de a ferrovia concedida à MRS corresponder a $7 \%$ da extensão total destas sete malhas.

${ }^{146}$ Nestes cálculos não foram computadas as participações das ferrovias EFA, EFJ e EFT.
} 
em 1997, juntamente com a Estrada de Ferro Vitória a Minas $\left(\right.$ EFVM) ${ }^{147}$; ambas por um prazo de 30 anos. Antes de sua privatização, a CVRD já detinha a concessão de ambas as ferrovias, por prazo indeterminado.

Com extensão total de $1.797 \mathrm{~km}$ (6,3\% do total global), estas ferrovias são utilizadas, primordialmente, para o escoamento de minério de ferro por terminais portuários operados pela mineradora nos estados do Maranhão (Terminal Portuário de Ponta da Madeira - TPPM, em São Luís) e Espírito Santo (Porto de Tubarão, em Vitória). Em 2013, a produção total de transporte de cargas destas ferrovias foi de 173,0 bilhões de TKU (58,2\% do total global), destacando-se como as duas ferrovias mais produtivas do país. A EFC também apresentou, no mesmo ano, a maior velocidade média de percurso entre as ferrovias brasileiras, de 48,0 $\mathrm{km} / \mathrm{h}$, enquanto a EFVM alcançou a segunda colocação, com velocidade média de $41,0 \mathrm{~km} / \mathrm{h}$.

Outras três concessões deste grupo compreendem adicionalmente à operação e conservação das vias, obrigações relacionadas à expansão da malha. São elas: Ferrovia Norte-Sul, ALL Malha Norte (ALLMN) e Ferroeste. Em 2013, a produção de transporte destas ferrovias totalizou 23,1 bilhões de TKU (7,8\% do total global), com velocidade média de percurso de $17,5 \mathrm{~km} / \mathrm{h}$.

A concessão da Ferrovia Norte-Sul foi outorgada à estatal Valec - Engenharia, Construções e Ferrovias S.A por meio do Decreto n 94.813 , de 01/09/1987. Em dezembro de 2007, a Valec firmou contrato de sub-concessão, pelo prazo de 30 anos, de $720 \mathrm{~km} \mathrm{da}$ ferrovia, no trecho compreendido entre Açailândia (MA) e Porto Nacional (TO) - à época este trecho apresentava seções ainda em construção ${ }^{148}$. A sub-concessionária Ferrovia Norte-

\footnotetext{
147 Outra particularidade da EFC e da EFVM é que elas são as únicas a também operar o transporte regular de passageiros de longa distância, juntamente com a Estrada de Ferro Amapá.

148 A construção do trecho Açailândia (MA) - Porto Nacional (TO) da Ferrovia Norte-Sul foi concluída em 2010.
} 
Sul S.A. (FNS), atualmente controlada pela VLI S.A. ${ }^{149}$, iniciou a operação da ferrovia em 2008

A concessão, pelo prazo de 90 anos, envolvendo a construção da Malha Norte foi outorgada à Ferronorte - Ferrovias Norte Brasil S.A. em 1989. O contrato incluía obrigações relacionadas à construção de quatro linhas, partindo de Cuiabá (MT) e tendo como destinos: i) Uberaba ou Uberlândia (MG); ii) Santa Fé do Sul (SP) - em 1998, modificado para Aparecida do Taboado (MS); iii) Porto Velho (RO); e iv) Santarém (PA). Os dois primeiros trechos deveriam ser construídos em seis anos. A construção do trecho a partir de Aparecida do Taboado foi iniciada em $1992^{150}$ e o primeiro trecho teve a operação iniciada em 2000. Em outubro de 2010, o objeto do contrato foi modificado, excluindo-se da concessão os trechos sem obras iniciadas, mantendo-se, desta forma, apenas o trecho compreendido entre Aparecida do Taboado (MS) e Rondonópolis (MT), com extensão total de 754 km. Em setembro de 2013, foi inaugurada a última seção integrante da concessão, entre Itiquira (MT) e Rondonópolis (MT). Desde 2006, a América Latina Logística S.A. é a controladora da concessionária da Malha Norte (ALLMN).

A concessão da Ferroeste - Estrada de Ferro Paraná Oeste S.A. foi outorgada à empresa estatal Ferroeste S.A., controlada pelo Governo do Estado do Paraná, com contrato firmado em maio de 1989 pelo prazo de 90 anos. A concessão compreende a construção de dois trechos ferroviários, o primeiro entre Guarapuava e Cascavel, no Estado do Paraná (PR), e o segundo, de Cascavel à região de Dourados, Estado do Mato Grosso do Sul. Apenas o trecho entre Guarapuava e Cascavel $(248 \mathrm{~km})$ se encontra construído.

\footnotetext{
149 Além da FNS, a VLI controla a FCA. A composição acionária da VLI é assim distribuída: Vale (64,1\%), Mitsui (20\%) e FI-FGTS (15,9\%). Em dezembro de 2013, a Vale celebrou um acordo com o fundo de investimento gerido pela Brookfield Asset Management para a venda de uma participação adicional de 26,5\% na VLI. A transação ainda está sujeita às condições precedentes, incluindo a aprovação do Conselho Administrativo de Defesa Econômica (Cade) e da ANTT. (OLIVEIRA, 2014) 
As últimas três ferrovias deste grupo são de cunho predominantemente industrial. A Estrada de Ferro Trombetas, concedida à empresa Mineração Rio do Norte S.A. $\left(\right.$ MRN) ${ }^{151}$, é destinada ao transporte de bauxita entre a Serra do Saracá e o Porto Trombetas, terminal de uso privado operado pela mesma empresa, ambos localizados em Oriximiná, estado do Pará. A Estrada de Ferro Jari (EFJ) e a Estrada de Ferro Amapá (EFA) foram construídas com o objetivo de servir para o transporte, respectivamente, de madeira cultivada para a fábrica de celulose do Projeto Jari, no estado do Pará, e de manganês da Serra do Navio, no estado do Amapá. Atualmente a EFA, concedida à Zamin Amapá Logística ${ }^{152}$, é utilizada para o escoamento de minério de ferro através do Porto de Santana (AP).

\footnotetext{
${ }^{151}$ A composição acionária da MRN é formada por: Vale (40\%), BHP Billiton (14,8\%), Rio Tinto Alcan (12\%), CBA (10\%), Alcoa Alumínio (8,58\%), Alcoa World Alumina (5\%), Hydro (5\%) e Alcoa AWA Brasil (4,62\%) (MINERAÇÃO RIO DO NORTE - MRN, 2014)

${ }^{152}$ Empresa do Grupo Zamin Ferrous, dedicado a projetos minerais no Brasil e no Uruguai (ZAMIN, 2014).
} 
Tabela 6 - Grupo II - Demais ferrovias em operação no Brasil - 2013 (extensão total: 3.815,4 $\mathrm{km})$

\begin{tabular}{|c|c|c|c|c|c|c|}
\hline Malha & Controlador & $\begin{array}{l}\text { Concessionária - } \\
\text { Denominação atual } \\
\text { (Subconcessionária) }\end{array}$ & Outorga & Particularidades & $\begin{array}{l}\text { Prazo de } \\
\text { concessão }\end{array}$ & $\begin{array}{c}\text { Extens } \\
\text { ão em } \\
2013 \\
(\mathbf{k m})\end{array}$ \\
\hline $\begin{array}{l}\text { EFVM - } \\
\text { Estrada de } \\
\text { Ferro } \\
\text { Vitória a } \\
\text { Minas }\end{array}$ & VALE & $\begin{array}{l}\text { EFVM - Estrada de } \\
\text { Ferro Vitória a Minas }\end{array}$ & $\begin{array}{c}\frac{\text { Decreto s/n de }}{27 / 06 / 1997} \\
\frac{\text { Decreto } 22.221, \text { de }}{03 / 12 / 1946} \\
\text { (REVOGADO) }\end{array}$ & $\begin{array}{l}\text { transporte de minério } \\
\text { de ferro, entre as minas } \\
\text { do Estado de Minas } \\
\text { Gerais e o Porto de } \\
\text { Tubarão (ES) }\end{array}$ & $\begin{array}{l}30 \text { anos, a } \\
\text { partir de } \\
30 / 06 / 1997\end{array}$ & 905 \\
\hline $\begin{array}{l}\text { EFC - } \\
\text { Estrada de } \\
\text { Ferro } \\
\text { Carajás }\end{array}$ & VALE & $\begin{array}{l}\text { EFC - Estrada de } \\
\text { Ferro Carajás }\end{array}$ & $\begin{array}{l}\frac{\text { Decreto s/n de }}{\underline{27 / 06 / 1997}} \\
\frac{\text { Decreto 87.691, de }}{\underline{21 / 12 / 1982}} \\
\text { (REVOGADO) }\end{array}$ & $\begin{array}{l}\text { transporte de minério } \\
\text { de ferro, entre Carajás e } \\
\text { Ponta da Madeira (MA) }\end{array}$ & $\begin{array}{l}30 \text { anos, a } \\
\text { partir de } \\
30 / 06 / 1997\end{array}$ & 892 \\
\hline $\begin{array}{l}\text { Ferrovia } \\
\text { Norte-Sul: } \\
\text { Açailândia } \\
\text { - Porto } \\
\text { Nacional }\end{array}$ & $\begin{array}{l}\text { VLI: VALE }(64,1 \%) \text {, } \\
\text { Mitsui }(20 \%) \text { e FI- } \\
\text { FGTS }(15,9 \%)\end{array}$ & $\begin{array}{l}\text { Valec - Engenharia, } \\
\text { Construções e } \\
\text { Ferrovias S.A. } \\
\text { (Subconcessionária: } \\
\text { FNS - Ferrovia Norte- } \\
\text { Sul S.A.) }\end{array}$ & $\begin{array}{c}\frac{\text { Decreto }^{\circ} 94.813, \text { de }}{01 / 09 / 1987 \text { (Contrato }} \\
\text { de subconcessão } \\
\text { firmado em } \\
20 / 12 / 2007)\end{array}$ & $\begin{array}{l}\text { A concessão prevê } \\
\text { obrigações de } \\
\text { construção da Ferrovia } \\
\text { Norte-Sul. }\end{array}$ & $\begin{array}{c}30 \text { anos } \\
\text { (subconcessão } \\
\text { ) }\end{array}$ & 720 \\
\hline Ferronorte & ALL & $\begin{array}{l}\text { ALLMN - América } \\
\text { Latina Logística } \\
\text { Malha Norte S.A. }\end{array}$ & $\begin{array}{l}\text { Decreto } .^{\circ} 97.739, \\
\text { de } 12 / 05 / 1989 \\
\text { (Contrato assinado } \\
\text { em } 19 / 05 / 1989)\end{array}$ & $\begin{array}{l}\text { Concessão abrangendo } \\
\text { construção entre } \\
\text { Aparecida do Taboado } \\
\text { (MS) e Rondonópolis } \\
\text { (MT), concluída em } \\
2013 .\end{array}$ & 90 anos & 754 \\
\hline Ferroeste & $\begin{array}{l}\text { Governo do Estado } \\
\text { do Paraná }\end{array}$ & $\begin{array}{l}\text { Ferroeste - Ferrovia } \\
\text { Paraná S.A. }\end{array}$ & $\frac{\text { Decreto n. } .^{\circ} 96.913,}{\underline{\text { de } 03 / 10 / 1988}}$ & $\begin{array}{l}\text { A concessão abrange a } \\
\text { construção dos trechos: } \\
\text { i) Guarapuava - } \\
\text { Cascavel (já } \\
\text { construído); ii) (a } \\
\text { construir) Cascavel - } \\
\text { Guaíra - Dourados }\end{array}$ & 90 anos & 248 \\
\hline $\begin{array}{l}\text { EFA - } \\
\text { Estrada de } \\
\text { Ferro } \\
\text { Amapá }\end{array}$ & Grupo Zamin Ferrous & $\begin{array}{l}\text { Zamin Amapá } \\
\text { Logística }\end{array}$ & $\begin{array}{c}\text { Contrato assinado em } \\
09 / 03 / 2006\end{array}$ & $\begin{array}{c}\text { Ferrovia industrial } \\
\text { privativa: transporte de } \\
\text { manganês entre a Serra } \\
\text { do Navio e o Porto de } \\
\text { Santana }\end{array}$ & $\begin{array}{c}20 \text { anos, a } \\
\text { partir de } \\
09 / 03 / 2006\end{array}$ & 194 \\
\hline $\begin{array}{l}\text { EFJ - } \\
\text { Estrada de } \\
\text { Ferro Jari }\end{array}$ & & Jari Celulose S.A. & 1979 & $\begin{array}{l}\text { Ferrovia industrial: } \\
\text { transporte de celulose, } \\
\text { bauxita, madeira } \\
\text { cultivada e brita }\end{array}$ & & 68 \\
\hline $\begin{array}{l}\text { EFT - } \\
\text { Estrada de } \\
\text { Ferro } \\
\text { Trombetas }\end{array}$ & $\begin{array}{l}\text { VALE }(40 \%), \text { BHP } \\
\text { Billiton }(14,8 \%), \text { Rio } \\
\text { Tinto Alcan }(12 \%), \\
\text { CBA }(10 \%), \text { Alcoa } \\
\text { Alumínio }(8,58 \%), \\
\text { Alcoa World } \\
\text { Alumina }(5 \%), \\
\text { Hydro }(5 \%) \text { e Alcoa } \\
\text { AWA Brasil }(4,62 \%)\end{array}$ & $\begin{array}{l}\text { Mineração Rio do } \\
\text { Norte S/A. }\end{array}$ & $\frac{\text { Decreto }^{\circ} 81.889, \text { de }}{\underline{05 / 07 / 1978}}$ & $\begin{array}{l}\text { Ferrovia industrial: } \\
\text { transporte de bauxita }\end{array}$ & & 35 \\
\hline
\end{tabular}

Fonte: ANTT (2014e) 


\subsubsection{EFEITOS DAS CONCESSÕES DAS MALHAS DA ANTIGA RFFSA}

“O surgimento da Rede Ferroviária Federal, em 1957, veio aglutinar as malhas independentes dispersas pelo país."153. A RFFSA havia sido estabelecida com o mandato de sanear as perdas financeiras acumuladas pelas ferrovias sob administração pública, que foram responsáveis por $81 \%{ }^{154}$ do déficit público do país na média do período 1954-1956. Quatro décadas mais tarde, a gigante estatal acumulava dívidas da ordem de R 33 bilhões ${ }^{155}$, possuía bens patrimoniais estimados em cerca de R $\$ 16,7$ bilhões, empregava 44,6 mil pessoas ${ }^{156} \mathrm{e}$ atendia 19 Unidades da Federação com uma malha de 22.069 km de extensão. ${ }^{157}$

Uma das motivações centrais apontada por CASTRO (2002) que norteou o programa de concessões das malhas da RFFSA era de ordem fiscal. De fato, as concessões produziram o esperado alívio às contas públicas. Conforme ressaltado pela Confederação Nacional do Transporte - CNT, as concessões possibilitaram recolhimento total à União de $\mathrm{R} \$ 1,764$ bilhão (preços auferidos nos leilões das malhas da RFFSA, em valores correntes) e desoneração dos cofres públicos da ordem de $\mathrm{R} \$ 300$ milhões por ano, correspondentes aos déficits anuais de operação das malhas da RFFSA à época da desestatização.

As concessões das ferrovias da antiga RFFSA também favoreceram o aumento de produtividade das linhas férreas brasileiras. Na média, o desempenho das ferrovias melhorou expressivamente; a produtividade por quilometragem foi ampliada de $1.770 \mathrm{mil} \mathrm{TKU} / \mathrm{km}$ em 1994, para $4.103 \mathrm{mil} \mathrm{TKU/km} \mathrm{em} \mathrm{2013,} \mathrm{correspondente} \mathrm{a} \mathrm{um} \mathrm{aumento} \mathrm{superior} \mathrm{a} \mathrm{230 \%} \mathrm{no}$ intervalo de quase 20 anos. Resultados ainda mais positivos foram obtidos em termos de

\footnotetext{
${ }^{153}$ Decisão TCU no $138 / 96$ - Plenário - Ata 13/96

154 Cf. dados de BAER, KERSTENETZKY e SIMONSEN (1962)

${ }^{155}$ Cf. Relatório conclusivo do estudo prévio da privatização da RFFSA elaborado pela Associação Nova Ferrovia (1995), cerca de $\mathrm{R} \$ 1$ bilhão, correspondia a passivos trabalhistas.

${ }^{156}$ Dados referentes a 1994.

${ }^{157}$ Decisão TCU no $138 / 96$ - Plenário - Ata 13/96
} 
ganhos de produtividade por empregado, com acréscimos superiores a $450 \%$ no mesmo período (de 796 mil TKU/empregado em 1994 para 3.735 mil TKU/empregado em 2013).

Conforme publicado pelo BNDES (2000), a concessão das malhas da RFFSA tinha como expectativas adicionais:

- geração de investimentos na recuperação, modernização e ampliação da infraestrutura existente;

- captação de recursos privados a fim de alavancar recursos adicionais ao setor ferroviário;

- redução do número de acidentes e aumento da produção do sistema;

- retomada da geração de encomendas de equipamentos e sistemas novos, bem como recuperação e modernização do material rodante degradado à indústria nacional de equipamentos e materiais ferroviários que se encontrava ociosa;

- capacitação da ferrovia para assunção de um novo papel na matriz modal brasileira: operação de cargas não cativas no intuito de reduzir o custo de transporte de cargas no Brasil, o que traria impactos positivos no custo da mercadoria consumida internamente e na competitividade do produto brasileiro no exterior.

Abaixo serão analisados alguns resultados referentes às malhas da antiga RFFSA, considerando-se aspectos operacionais, de segurança, produtividade e investimento.

\section{A. PRODUÇÃO DE TRANSPORTE: PROJETADA X REALIZADA}

Nos estudos associados às licitações das malhas da RFFSA, foram projetadas demandas potenciais de transporte ferroviário para o ano de 2002 (2010 no caso do Malha 
Paulista) ${ }^{158}$, considerando-se as demandas existentes à época somadas a demandas incrementais - definidas com base nas áreas geográficas e segmentos de mercado atendidos por outros modais e que poderiam ser "capturadas" pela ferrovia. Nestas projeções, foram consideradas taxas equivalentes a uma média de crescimento anual de $13,3 \%$ na produção de transporte a partir de 1994.

Tomando-se como referência os valores projetados e comparando-os com a produção efetivamente realizada em 2002 (2010 no caso da Malha Paulista), verifica-se, conforme a Tabela 7 que a produção global realizada foi inferior a $50 \%$ do potencial estimado nos estudos de viabilidade que embasaram as concessões. Na análise individual, nota-se que exceto pela FTC, as demais ferrovias apresentaram resultados aquém do projetado para o horizonte de 2002 (2010 para a Malha Paulista), destacando-se negativamente as Malhas Nordeste e Paulista, que produziram efetivamente menos de $20 \%$ do valor estimado e as Malhas Centro-Leste e Oeste, que alcançaram menos de 35\% do total projetado para o ano de referência. Observa-se que esses resultados seguem de perto benchmark internacional. De fato, conforme estimado por Flyvbjerg (2006 apud DEHORNOY, 2012) ${ }^{159}, 72 \%$ (84\%) dos projetos ferroviários apresentam tráfego real inferior ao projetado em percentuais superiores a $40 \%(20 \%)$.

\footnotetext{
${ }^{158}$ As demandas potenciais constam dos editais de concessão das malhas da RFFSA. Chama a atenção o fato de apenas no edital da malha oeste ter sido incluída informação acerca da capacidade da ferrovia, de 2 bilhões de TKU/ano.

${ }^{159}$ DEHORNOY (2012, p.9)
} 
Tabela 7 - Ferrovias da antiga RFFSA: Produção de transporte (milhões de TKU), por concessionária - 1994, 2002 (estimado e realizado), 2013

\begin{tabular}{|c|c|c|c|c|c|c|c|c|c|}
\hline \multirow[b]{2}{*}{ Malha } & \multirow[b]{2}{*}{$\begin{array}{l}\text { Concessionária } \\
\text { - Denominação } \\
\text { atual }\end{array}$} & \multicolumn{4}{|c|}{ Produção de transporte (milhões de TKU) } & \multirow[b]{2}{*}{$\begin{array}{c}\text { Variação } \\
\text { anual média } \\
2002 / 2013 \\
(\%)\end{array}$} & \multicolumn{3}{|c|}{ Comparativo } \\
\hline & & $\begin{array}{c}\text { Realizado } \\
1994\end{array}$ & $\begin{array}{l}\text { Potencial } \\
\text { estimado } \\
2002\end{array}$ & $\begin{array}{l}\text { Realiza } \\
\text { do } 2002\end{array}$ & $\begin{array}{c}\text { Realizado } \\
\mathbf{2 0 1 3}\end{array}$ & & $\begin{array}{c}2002- \\
\text { (Real- } \\
\text { Potencial) } \\
\text { /Potencial } \\
\quad(\%)\end{array}$ & $\begin{array}{c}2013 / \\
1994 \\
(\%)\end{array}$ & $\begin{array}{c}\text { 2013/ } \\
\text { Potencial } \\
2002\end{array}$ \\
\hline Oeste & ALLMO & $1.916,0$ & $5.200,0$ & $1.707,5$ & $1.484,0$ & $-1,3$ & $-67,2 \%$ & 77,5 & 28,5 \\
\hline $\begin{array}{l}\text { Centro- } \\
\text { Leste }\end{array}$ & FCA & $6.951,0$ & $26.598,0$ & $8.608,0$ & $17.789,0$ & 6,8 & $-67,6 \%$ & 255,9 & 66,9 \\
\hline Sudeste & MRS & $20.370,0$ & $37.583,0$ & $29.431,0$ & $61.468,0$ & 6,9 & $-21,7 \%$ & 301,8 & 163,6 \\
\hline $\begin{array}{l}\text { Tereza } \\
\text { Cristina }\end{array}$ & FTC & 96,0 & 160,0 & 191,3 & 239,0 & 2,0 & $19,6 \%$ & 249,0 & 149,4 \\
\hline Sul & ALLMS & $9.021,0$ & $24.335,0$ & $12.830,2$ & $15.789,0$ & 1,9 & $-47,3 \%$ & 175,0 & 64,9 \\
\hline Nordeste & TLSA & 927,0 & $4.440,0$ & 756,7 & 535,0 & $-3,1$ & $-83,0 \%$ & 57,7 & 12,0 \\
\hline \multirow[t]{2}{*}{ Paulista } & ALLMP & $6.473,0$ & $20.972 *$ & $4.004 *$ & $3.912,0$ & $-6,6$ & $-80,9 \% *$ & 60,4 & $18,7 *$ \\
\hline & $\begin{array}{l}\text { TOTAL } \\
\text { GLOBAL }\end{array}$ & $45.754,0$ & $119.288,0 *$ & $\begin{array}{r}\mathbf{5 7 . 5 2 8 , 7} \\
*\end{array}$ & $101.216,0$ & & $-51,8 \% *$ & 221,2 & \\
\hline
\end{tabular}

Fonte: Editais de concessão e ANTT (2014e)

Obs.: * Para a ALLMP, ao invés de 2002, o número se refere ao ano de 2010.

Ao se comparar o volume de produção realizada em 2013 com o potencial estimado para o ano de 2002 (2010 no caso da Malha Paulista), verifica-se que apenas duas concessionárias (MRS e FTC) lograram superar os valores projetados para o ano de referência. Como resultado desta análise, pode-se levantar duas hipóteses: as projeções de crescimento de demanda foram demasiadamente superestimadas ou as ferrovias então privatizadas não tiveram êxito em captar a demanda potencial, tendo sido esta atendida por outros modais.

\section{B. EVOLUÇÃO DA PRODUÇÃO DE TRANSPORTE}

As ferrovias da antiga RFFSA apresentaram aumento significativo na produção após serem concedidas ao setor privado. Enquanto em 1994, previamente aos leilões de concessão, a produção de transporte totalizou 45,7 bilhões de TKU, em 2013 foi registrada produção de 101,2 bilhões de TKU, o que representou uma expansão de 121,2\%, correspondente a um 
crescimento médio anual de 3,0\%. Assinala-se que no mesmo período, o PIB brasileiro apresentou elevação de $74,3 \%{ }^{160}$.

A Figura 7 apresenta a evolução da produção de transporte ferroviário, total e por concessionária, e a evolução do volume exportado de minério de ferro pelo Brasil, no período 2001-2013, tendo 1994 como ano-base.

Da análise individual, pode-se depreender que os resultados alcançados pelas concessionárias foram bastante heterogêneos. Conforme indicado, os principais destaques foram, mais uma vez, a MRS, que em 2013 alcançou produção três vezes maior que a registrada em 1994, e as concessionárias FCA e a FTC, que ampliaram duas vezes e meia a produção na comparação 2013/1994. No outro extremo, observa-se que em três casos (ALLMO, ALLMP e TLSA ${ }^{161}$ ) a produção de transporte tem-se mantido estagnada, em patamares inferiores a aqueles que se tinha previamente às concessões.

Pode-se também observar no gráfico, que a produção de transporte ferroviário acompanhou de perto a variação no volume de exportações de minério de ferro, sendo possível concluir que o crescimento da produção ferroviária verificada nos últimos dez anos ocorreu, sobretudo, pela expansão da demanda e vendas internacionais do mineral.

\footnotetext{
${ }^{160}$ Cf. BCB-Depec (2014). Série: 1208 - Produto interno bruto em R\$ do último ano (2013).

${ }^{161}$ Conforme consta no Acórdão TCU n ${ }^{\circ}$ 621, de 16/09/1998, previamente à concessão, a Malha Nordeste tinha capacidade para o transporte de 1 bilhão de TKU, ou seja, apenas um pouco acima da produção total de 1994 (927 milhões de TKU). Disponível em:

<http://www.tcu.gov.br/Consultas/Juris/Docs/judoc/SIDOC/geradoSIDOC DC06213898P.pdf>
} 
Figura 7 - Ferrovias da antiga RFFSA: Índice da evolução da produção de transporte, total e por concessionária, 2001 a 2013; Índice da evolução do volume exportado pelo Brasil de minério de ferro - Ano-base: 1994

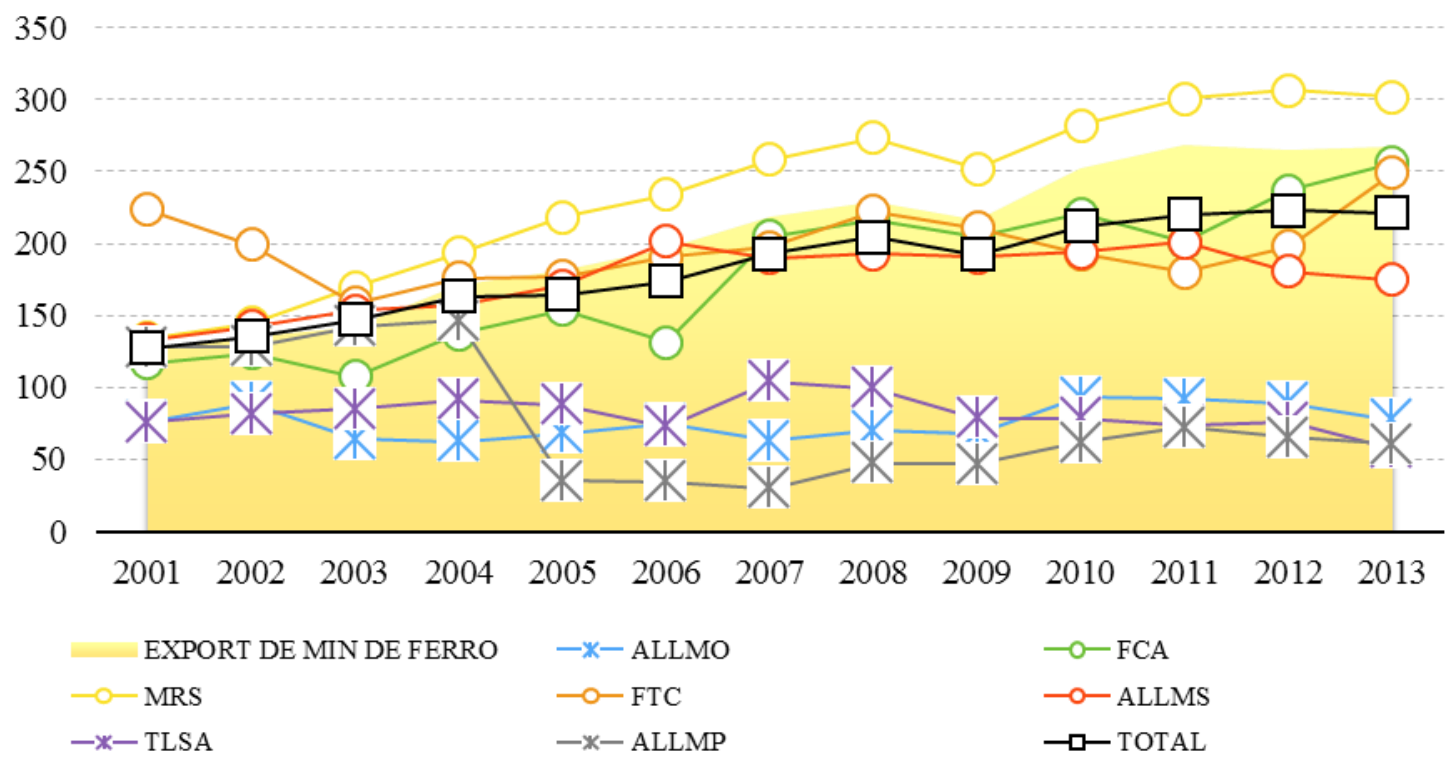

Fonte: ANTT (2014e)

Obs.: Ano-base: 1994 (índice 100)

\section{PRODUÇÃO DE TRANSPORTE: REALIZADO X META}

Conforme mencionado, nos contratos de concessão foram estabelecidas ${ }^{162}$ metas anuais de produção referentes aos cinco ${ }^{163}$ primeiros anos de contrato. Para os dois quinquênios subsequentes, foram pactuadas novas metas de produção de transporte, por concessão. Em caso de não cumprimento, as penalidades aplicáveis são reguladas pela Resolução da ANTT n ${ }^{\circ}$ 288, de 10/09/2003.

A Tabela 8 indica o nível de atendimento das metas anuais de produção, por concessionária, no período 2003-2011 ${ }^{164}$. Conforme se observa, a MRS e a FTC foram as que apresentaram melhores índices de cumprimento de metas no período considerado. A MRS

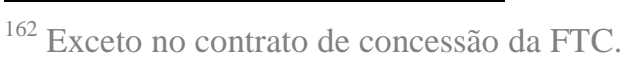

${ }^{163}$ Três primeiros anos no caso da Malha Paulista, cf. contrato de concessão da ALLMP.

164 Tendo em vista que a regulamentação da aplicação de penalidades pelo não cumprimento de metas contratuais ocorreu apenas em 2003
} 
superou a meta de produção em todos os anos do período considerado. Já a FTC, teve performance semelhante, exceto para o ano de 2011, em que a produção foi 1,3 p.p. menor que a meta estabelecida.

Por outro lado, a ALLMO, seguida pela TLSA, apresentaram os piores níveis de atendimento às metas estabelecidas, contudo, de forma distinta. A ALLMO apresentou níveis de produção inferiores às metas até 2009, enquanto em 2010 e 2011, reverteu este histórico, superando as metas para os respectivos anos. No caso da TLSA, ainda que se verifique uma melhoria significativa a partir de 2008, com valores de produção mais próximos das metas estabelecidas, nota-se que a concessionaria não cumpriu a meta em nenhum ano do período analisado.

Tabela 8 - Ferrovias da antiga RFFSA: Produção de Transporte - Realizado / Meta (\%), por concessionária - 2003 a 2011

$\begin{array}{llrrrrrrrrr}\text { Malha } & \text { Concessionári } & \mathbf{2 0 0 3} & \mathbf{2 0 0 4} & \mathbf{2 0 0 5} & \mathbf{2 0 0 6} & \mathbf{2 0 0 7} & \mathbf{2 0 0 8} & \mathbf{2 0 0 9} & \mathbf{2 0 1 0} & \mathbf{2 0 1 1} \\ & \begin{array}{l}\text { a - } \\ \text { Denominação } \\ \text { atual }\end{array} & & & & & & & & & \\ & & & & & & & & & \\ \text { Oeste } & \text { ALLMO } & \text { n.d } & \text { n.d* } & 67,2 & 56,3 & 37,8 & 34,2 & 32,2 & 126,7 & 119,6 \\ \begin{array}{l}\text { Centro- } \\ \text { Leste }\end{array} & \text { FCA } & 85,0 & 100,2 & 103,0 & 90,4 & 91,4 & 104,0 & 102,6 & 106,6 & 94,6 \\ \text { Sudeste } & \text { MRS } & 115,4 & 125,5 & 134,1 & 135,1 & 143,1 & 113,2 & 100,2 & 108,1 & 111,0 \\ \text { Tereza } & \text { FTC } & 116,9 & 130,0 & 130,8 & 140,7 & 145,7 & 122,4 & 115,4 & 105,7 & 98,7 \\ \text { Cristina } & & & & & & & & & & \\ \text { Sul } & \text { ALLMS } & 103,4 & 101,3 & 106,3 & 121,1 & 112,2 & 98,2 & 93,6 & 92,1 & 100,8 \\ \begin{array}{l}\text { Nordest } \\ \text { e }\end{array} & \text { TLSA } & \text { n.d } & \text { n.d* } & 80,0 & 48,6 & 52,7 & 98,9 & 78,5 & 94,6 & 92,5 \\ \text { Paulista } & \text { ALLMP } & \text { n.d } & \text { n.d } & 153,3 & 104,5 & 71,0 & 89,7 & 181,8 & 113,2 & 120,6\end{array}$

Fonte: ANTT (2014e)

Obs. 1: n.d: não disponível.

Obs. 2: *Ano sem meta estabelecida

Obs. 3: Os valores em vermelho indicam não cumprimento às metas de produção

Ainda que as metas estabelecidas possibilitem a avaliação geral do desempenho operacional de cada concessionária, nota-se que as grandes extensões das malhas, associadas a performances diferenciadas por trecho, poderiam resultar em uma avaliação parcial do nível de atendimento oferecido por cada concessionária. 
Com vistas a minimizar este aspecto, em 2011, a ANTT aprovou um conjunto de regras para a pactuação de metas de produção por trecho ferroviário ${ }^{165}$, em utilização a partir do estabelecimento das metas referentes ao ano de 2012 e para o período 2013-2017. Conforme o inciso VI do art. $2^{\circ}$ do 'Regulamento para pactuar as metas de produção por trecho e metas de segurança para as concessionárias de serviço público de transporte ferroviário de cargas ${ }^{, 166}$, trecho ferroviário é o segmento da malha ferroviária delimitado por:

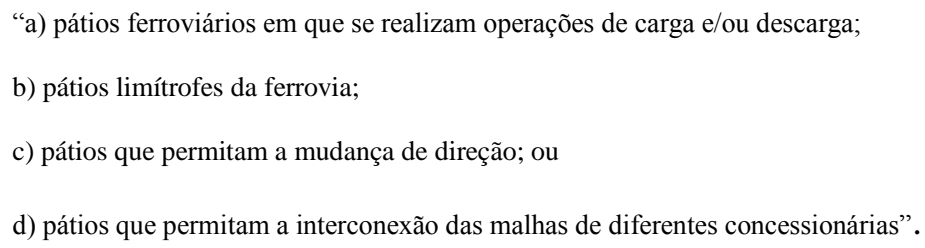

Em atendimento ao regulamento, as metas de produção passaram a ser pactuadas por trecho, - a partir da apresentação pelas concessionárias à ANTT de estudo de mercado, plano de negócios, inventário de capacidade por trecho, padrões operacionais dos trechos e cadastro de todas as estações operacionais ${ }^{167}$, sendo consideradas atendidas quando, em noventa por cento ou mais dos trechos, a meta de produção pactuada para o trecho tiver sido atingida.

A Tabela 9 apresenta os resultados obtidos no período 2012-2013, por concessionária, considerando-se a nova métrica de apuração do cumprimento de meta anual de produção. Conforme se observa, a FTC foi a única a cumprir a meta em mais de $90 \%$ dos trechos nos dois anos analisados. Em 2012, outras duas concessionárias cumpriram as metas estabelecidas em $90 \%$ ou mais dos trechos integrantes de suas respectivas malhas (a MRS e a ALLMP). Em 2013, nenhuma outra concessionária (além da FTC) atingiu a meta em pelo menos $90 \%$ de seus trechos. Em ambos os anos, a ALLMS e a TLSA atingiram as metas estabelecidas em menos de $45 \%$ e $25 \%$ dos trechos, respectivamente.

\footnotetext{
165 Observa-se que até então as metas eram estabelecidas por concessão.

${ }^{166}$ Resolução ANTT no 3.696/2011.

${ }^{167}$ Cf. art. $3^{\circ}$ do Anexo da Resolução ANTT nº 3.696/2011.
} 
Tabela 9 - Ferrovias da antiga RFFSA: Produção de Transporte - Atendimento de metas por trecho, por concessionária - 2012 e 2013

\begin{tabular}{|c|c|c|c|c|c|c|c|}
\hline & & & 2012 & & & 2013 & \\
\hline Malha & $\begin{array}{l}\text { Concessionária - } \\
\text { Denominação } \\
\text { atual }\end{array}$ & $\begin{array}{c}\mathrm{N}^{\mathrm{o}} \text { de } \\
\text { trechos } \\
\text { totais }\end{array}$ & $\begin{array}{c}\text { Mínimo a } \\
\text { ser } \\
\text { atendido }\end{array}$ & $\begin{array}{c}\text { Realizado/ } \\
\text { Mínimo } \\
(\%)\end{array}$ & $\begin{array}{c}\mathrm{N}^{0} \text { de } \\
\text { trechos } \\
\text { totais }\end{array}$ & $\begin{array}{c}\text { Mínimo a } \\
\text { ser } \\
\text { atendido }\end{array}$ & $\begin{array}{c}\text { Realizado/ } \\
\text { Mínimo } \\
(\%)\end{array}$ \\
\hline Oeste & ALLMO & 27 & 24 & 96 & 27 & 24 & 42 \\
\hline $\begin{array}{l}\text { Centro- } \\
\text { Leste }\end{array}$ & FCA & 80 & 72 & 69 & 90 & 81 & 38 \\
\hline Sudeste & MRS & 73 & 65 & 102 & 85 & 76 & 54 \\
\hline $\begin{array}{l}\text { Tereza } \\
\text { Cristina }\end{array}$ & FTC & 7 & 6 & 117 & 7 & 6 & 117 \\
\hline Sul & ALLMS & 104 & 93 & 43 & 104 & 93 & 39 \\
\hline Nordeste & TLSA & $43^{*}$ & $38 *$ & 21 & 51 & 45 & 11 \\
\hline Paulista & ALLMP & 34 & 30 & 100 & 39 & 35 & 86 \\
\hline
\end{tabular}

Fonte: ANTT (2014b; 2014c)

Obs. 1: * O relatório não apresenta o valor, apenas o gráfico.

Obs. 2: Os valores em vermelho indicam não cumprimento às metas de produção

\section{EVOLUÇÃO DO ÍNDICE DE ACIDENTES}

A Figura 8 apresenta os valores anuais relativos ao índice de acidentes, por concessionária, entre os anos de 2003 e 2013.

$\mathrm{Na}$ análise agregada, pode-se observar que no período houve uma redução de $63,4 \%$ no índice de acidentes, dado que em 2003 foram registrados 46,2 acidentes por milhão de trem.km enquanto em 2013 o índice médio foi de 16,9 acidentes por milhão de trem.km. Para efeito de benchmark internacional, tem-se como referência o intervalo de 8 a 13 acidentes por milhão de trem.km.

$\mathrm{Na}$ análise individual, cabe destacar a melhoria apresentada pela ALLMO, que reduziu seu índice de acidentes de 150,9 acidentes por milhão de trem.km em 2003 para 23,1 acidentes por milhão de trem.km em 2013. Da mesma forma, a MRS, mais uma vez, se 
sobressaiu, alcançando os menores índices de acidentes em todos os anos do período 20052013. Por outro lado, nota-se que a Malha Nordeste apresentou os maiores índices de acidentes entre todas as malhas, em praticamente ${ }^{168}$ todos os anos do período em análise. Outro aspecto que merece atenção é o fato de que no período 2003-2005, em 2008 e entre 2010 e 2011, a Malha Nordeste apresentou índices de acidentes superiores aos registrados previamente à concessão, correspondente a 170 acidentes por milhão de trem.km em 1996, conforme indicado no edital de concessão.

Figura 8 - Ferrovias da antiga RFFSA: Número de acidentes / milhão de trem.km, média e por concessionária - 2003 a 2013

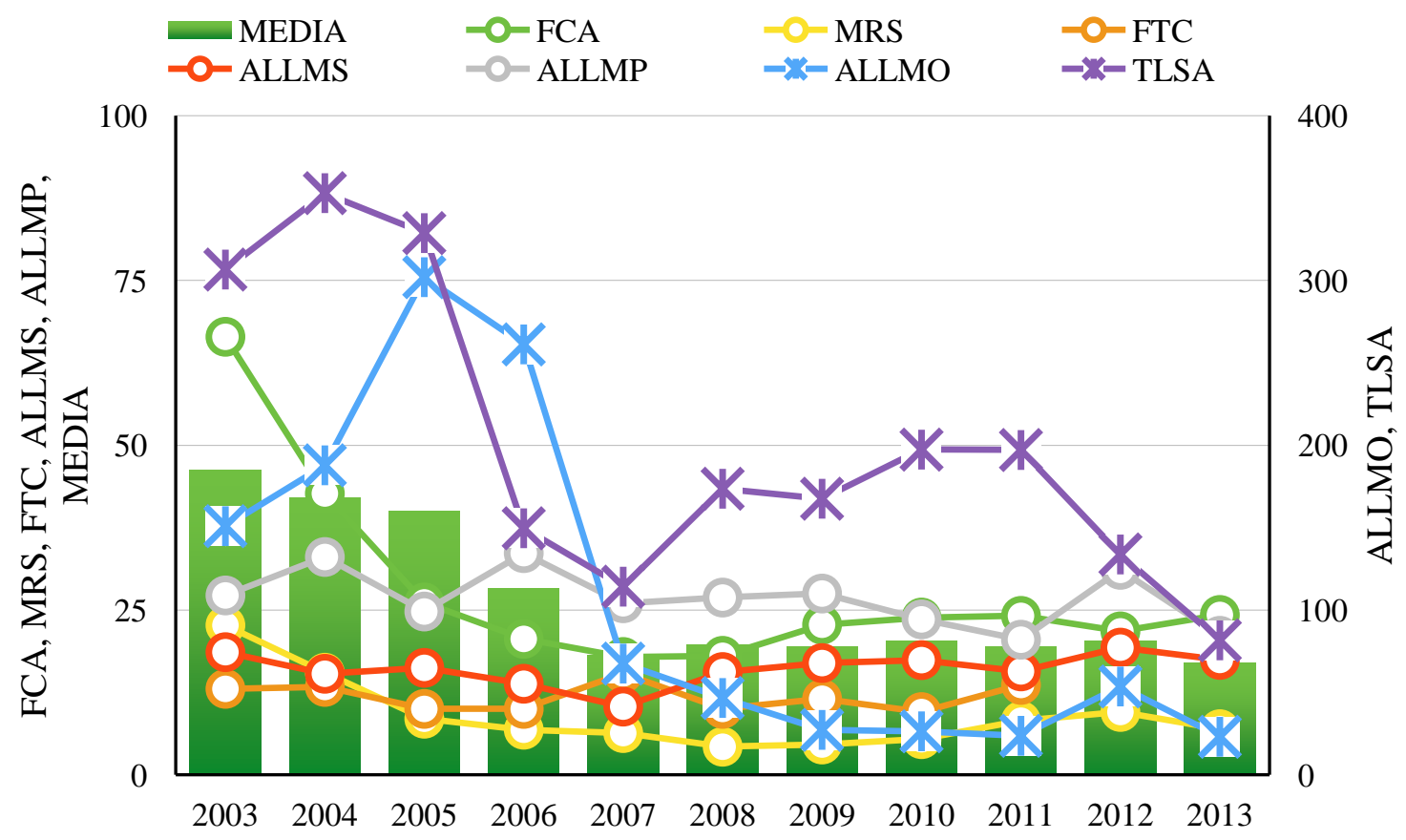

Fonte: ANTT (2014e)

E. SEGURANÇA OPERACIONAL: REALIZADO X META

${ }^{168}$ Exceto em 2006. 
Da mesma forma que as metas de produção, nos contratos de concessão foram estabelecidas metas anuais de redução de acidentes, para os cinco primeiros anos de contrato. Para os períodos subsequentes, foi previsto que as metas de segurança operacional seriam pactuadas, a cada cinco anos, entre as concessionárias e a Agência Reguladora.

Conforme dispõe a Resolução ANTT nº 3.696/2011, para o estabelecimento de metas de segurança operacional, devem ser levados em consideração valores referenciais internacionais, índices de acidentes nas concessões e os investimentos em segurança previstos pelas concessionárias ${ }^{169}$. Assim como para as metas de produção, em caso de não cumprimento das metas de redução de acidentes, as penalidades aplicáveis são reguladas pela Resolução ANTT nº 288, de 10/09/2003.

A Tabela 10 indica o nível de atendimento das metas anuais de segurança operacional, por concessionária, no período 2003-2013. Observa-se que a FTC, MRS e FCA cumpriram as metas de segurança em todos os anos do período analisado. Por outro lado, não foram cumpridas as metas de segurança estabelecidas para a Malha Nordeste em cinco dos nove anos com metas pactuadas.

${ }^{169}$ Cf. art. $5^{\circ}$ do Anexo da Resolução ANTT n 3.696/2011. 


\section{F. PRODUTIVIDADE (POR QUILOMETRAGEM E POR EMPREGADO) E VELOCIDADE MÉDIA DE PERCURSO}

Conforme apresentado na, verifica-se que houve, em média, ampliação de $131 \%$ na produtividade por quilometragem, na comparação $1994^{170} / 2013$. Contudo, analisando-se individualmente as sete malhas, constatam-se desempenhos diferenciados entre as ferrovias, tendo-se observado, inclusive, casos de queda de produtividade após a concessão (TLSA e ALLMO). Adicionalmente, constata-se que a produtividade por quilometragem da malha operada pela MRS foi ampliada em mais de $200 \%$ na comparação 1994/2013, tendo alcançado, em 2013, desempenho em mais de quinze vezes superior ao índice obtido pela segunda malha mais produtiva (FCA). Cabe também mencionar que a FCA e a FTC elevaram seus níveis de produtividade por quilometragem em cerca de $150 \%$ na comparação $1994 / 2013$.

Tabela 10 - Ferrovias da antiga RFFSA: (Número de acidentes / milhão de trem.km) / Meta de Segurança (\%), por Concessionária - 2003 a 2011

\begin{tabular}{|c|c|c|c|c|c|c|c|c|c|c|c|c|}
\hline Malha & $\begin{array}{l}\text { Concessi } \\
\text { onária - } \\
\text { Denomi } \\
\text { nação } \\
\text { atual }\end{array}$ & 2003 & 2004 & 2005 & 2006 & 2007 & 2008 & 2009 & 2010 & 2011 & 2012 & 2013 \\
\hline Oeste & ALLMO & n.d* & n.d* & 230,6 & 284,0 & 99,3 & 86,4 & 63,4 & 91,6 & 83,5 & 189,5 & 81,7 \\
\hline $\begin{array}{l}\text { Centro- } \\
\text { Leste }\end{array}$ & FCA & 97,7 & 68,3 & 45,5 & 42,1 & 44,7 & 64,5 & 84,4 & 88,8 & 91,5 & 84,3 & 94,0 \\
\hline Sudeste & MRS & 70,9 & 55,3 & 33,4 & 28,5 & 27,5 & 23,7 & 27,0 & 36,1 & 60,8 & 79,5 & 67,9 \\
\hline $\begin{array}{l}\text { Tereza } \\
\text { Cristina }\end{array}$ & FTC & 33,4 & 37,0 & 31,3 & 35,7 & 59,2 & 50,0 & 57,7 & 47,6 & 68,2 & 22,7 & 53,6 \\
\hline Sul & ALLMS & 53,2 & 45,8 & 50,7 & 44,6 & 35,7 & 86,7 & 94,2 & 98,9 & 90,7 & 113,6 & 105,0 \\
\hline Nordeste & TLSA & n.d* & n.d* & 117,4 & 68,0 & 65,3 & 124,0 & 139,7 & 164,5 & 123,2 & 91,9 & 59,6 \\
\hline Paulista & ALLMP & 30,9 & n.d* & 53,9 & 88,5 & 84,0 & 99,6 & 110,0 & 96,1 & 85,9 & 91,1 & 82,3 \\
\hline
\end{tabular}

Fonte: ANTT (2014e)

Obs. 1: n.d: não disponível.

Obs. 2: * Sem meta estabelecida

Obs. 3: Os valores em vermelho indicam não cumprimento às metas de redução de acidentes

1701995 no caso da Malha Paulista. 
Em termos de produtividade por empregado, nota-se que todas as ferrovias apresentaram expressivos ganhos de produtividade entre 1994 e 2013, com crescimento médio de $287 \%$, destacando-se a FCA e a ALLMP, com ganhos de produtividade superiores a 300\%. Outras três concessionárias, a ALLMS, a MRS e a FTC também apresentaram ganhos expressivos, superiores a $200 \%$ no período de 19 anos.

No exame das velocidades médias de percurso ${ }^{171}$ desenvolvidas pelas sete malhas em 2013, as antigas ferrovias da RFFSA registraram, em média, 18,2 km/h, alcançando a maior e a menor velocidade média, respectivamente, a MRS, com 33,0 km/h, e a TLSA, com 13,2 km/h. Para efeito de comparação, as Estradas de Ferros Carajás e a Vitória a Minas apresentaram, no mesmo ano, respectivamente, velocidades médias de percurso de 48,0 km/h e $41,0 \mathrm{~km} / \mathrm{h}$.

Tabela 11 - Ferrovias da antiga RFFSA: Produtividade por quilometragem (TKU/km) e Produtividade por empregado (TKU/empregado), por concessionária - 1994, 2013; Velocidade média de percurso $(\mathrm{km} / \mathrm{h})$, por concessionária - 2013; Distância Média de Viagem $(\mathrm{km})$, por concessionária - 2013

\begin{tabular}{|c|c|c|c|c|c|c|c|c|c|}
\hline \multirow[t]{2}{*}{ Malha } & \multirow[t]{2}{*}{$\begin{array}{l}\text { Concessionária } \\
\text { - Denominação } \\
\text { atual }\end{array}$} & \multirow{2}{*}{$\begin{array}{c}\text { Velocidade } \\
\text { média de } \\
\text { percurso } \\
2013 \\
(\mathbf{k m} / \mathbf{h})\end{array}$} & \multirow{2}{*}{$\begin{array}{c}\text { Distância } \\
\text { Média de } \\
\text { Viagem } \\
2013 \\
(\mathbf{k m})\end{array}$} & \multicolumn{3}{|c|}{$\begin{array}{l}\text { Produtividade por } \\
\text { quilometragem } \\
\text { (mil TKU / km) }\end{array}$} & \multicolumn{3}{|c|}{$\begin{array}{c}\text { Produtividade por } \\
\text { empregado } \\
\text { (mil TKU / empregado) }\end{array}$} \\
\hline & & & & 2013 & 1994 & $\begin{array}{c}\text { Var } \\
2013 / \\
1994 \\
(\%)\end{array}$ & 2013 & 1994 & $\begin{array}{c}\text { Var } \\
2013 / \\
1994 \\
(\%)\end{array}$ \\
\hline Oeste & ALLMO & 13,5 & 320,9 & 763 & 1.179 & -35 & 1.696 & 634 & 168 \\
\hline $\begin{array}{l}\text { Centro- } \\
\text { Leste }\end{array}$ & FCA & 23,1 & 776,0 & 2.395 & 974 & 146 & 2.759 & 531 & 420 \\
\hline Sudeste & MRS & 33,0 & 469,6 & 36.719 & 12.168 & 202 & 6.063 & 1.863 & 225 \\
\hline $\begin{array}{l}\text { Tereza } \\
\text { Cristina }\end{array}$ & FTC & 28,5 & 73,8 & 1.457 & 585 & 149 & 764 & 244 & 213 \\
\hline Sul & ALLMS & 15,0 & 688,3 & 2.173 & 1.403 & 55 & 2.866 & 809 & 254 \\
\hline
\end{tabular}

\footnotetext{
${ }^{171}$ Conforme relatório da ANTT (2014e), “a velocidade média de percurso anual representa a velocidade média desenvolvida pelo trem entre sua formação e encerramento, seja na chegada a estação de destino ou na passagem por estação de intercâmbio, descontado os tempos das paradas em pátios.”
} 


$\begin{array}{llrrrrrrrr}\text { Nordeste } & \text { TLSA } & 13,2 & 441,4 & 127 & 218 & -42 & 301 & 191 & 58 \\ \text { Paulista } & \text { ALLMP } & 13,8 & 733,1 & 1.967 & 1.415^{*} & 39 * & 1.921 & 446^{*} & 331^{*} \\ & \text { Média Geral } & \mathbf{1 8 , 2} & \mathbf{5 2 9 , 4} & \mathbf{4 . 1 0 3} & \mathbf{1 . 7 7 4} & \mathbf{1 3 1} & \mathbf{3 . 7 3 5} & \mathbf{9 6 6} & \mathbf{2 8 7}\end{array}$

Fonte: Editais de Concessão (1994) e ANTT (2014c)

Obs. 1: * Para a Malha Paulista, consideraram-se valores referentes a 1995.

Obs. 2: Os valores em vermelho indicam queda de produtividade na comparação 2013 x 1994.

\section{G. MERCADORIAS TRANSPORTADAS}

A Figura 9 apresenta um comparativo entre os anos de 1994 e 2013, relativo ao percentual de participação ${ }^{172}$ das principais mercadorias no total transportado pelas ferrovias da antiga RFFSA. Como se pode notar, o minério de ferro ampliou sua participação em 52,8\% na comparação 1994/2013, atingindo participação de 55,3\% em 2013. Em termos relativos, destacam-se os ganhos de participação dos grupos madeira, celulose e papel $(415,9 \%)$, complexo soja $(210,8 \%)$ e carga geral conteinerizada $(205,1 \%)$.

A ampliação na participação da carga geral conteinerizada no transporte pode ser vista como um aspecto positivo no sentido de intensificar o uso da ferrovia para o transporte de mercadorias de maior valor agregado, não cativas do setor. Conforme a ANTF (2014), entre as principais dificuldades associadas ao crescimento do transporte intermodal, que implicaria no aumento do número de contêineres transportados por ferrovia, estão: dificuldades associadas ao atual sistema tributário e à legislação de contêineres; ausência de incentivos fiscais para a construção de terminais multimodais; as condições deficientes de acesso ferroviário aos portos; e a falta de implementação do conhecimento de transporte eletrônico $(\mathrm{CTe})^{173}$.

\footnotetext{
${ }^{172}$ Considerando-se os volumes em TKU.

${ }^{173}$ Cf. (ANTT, 2012, p.14), 'conhecimento de transporte' é o “documento que caracteriza o contrato de transporte entre o transportador e o contratante do serviço, com origem e destino conforme pactuado entre as partes. Além das características fiscais e tributárias, este documento é portador de informações comerciais, gerenciais e destinadas aos órgãos de fiscalização dos transportes".
} 
Por outro lado, no mesmo período, verificaram-se maiores quedas nas participações relativas dos seguintes grupos de produtos: cimento $(-72,8 \%)$, combustíveis ${ }^{174}(-58,2 \%)$, produtos siderúrgicos $(-57,1 \%)$, adubos e fertilizantes $(-41,7 \%)$ e carvão/coque $(-34,6) \%$.

${ }^{174}$ Os combustíveis reduziram substancialmente sua participação, de 12,8\% em 1994 para 5,3\% em 2013, resultado impactado pela ampliação da utilização do modal dutoviário. 
Figura 9 - Participação, em TKU, das principais mercadorias transportadas pelas ferrovias da antiga RFFSA (\%) - 1994 e 2013

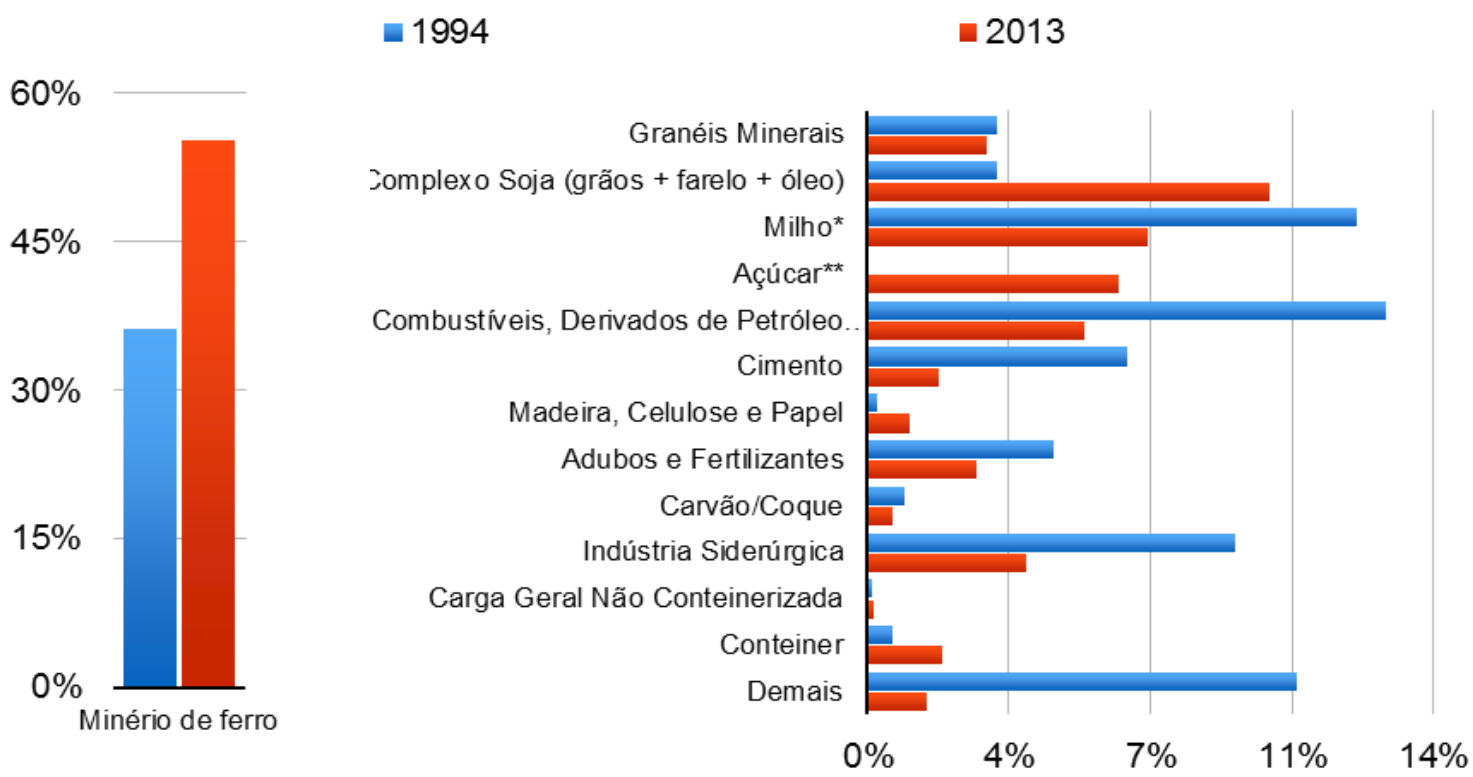

Fonte: Editais de Concessão (1994) e ANTT (2014c)

Obs. 1: * Os números de 1994 incluem outros produtos além do milho, como arroz, trigo, entre outros.

Obs. 2: ** Valor relativo a 1994 não disponível.

\section{H. EVOLUÇÃO DO NÚMERO DE CLIENTES}

A Figura 10 apresenta a variação, no período 2002 a 2011, no número de clientes com faturamento - total e por concessionária, com relação ao ano base de 2002. Verifica-se que até 2006, a tendência foi de ampliação na quantidade de clientes, enquanto a partir de 2007, pode-se observar inversão desta trajetória.

Em 2002, as concessionárias das malhas da antiga RFFSA atenderam um total de 839 clientes. Em 2006 foram atendidas 1.681 empresas, enquanto em 2011, a carteira de clientes totalizou 699 empresas, representando queda de $17 \%$ com relação ao número registrado em 2002, e redução de 58\%, com relação ao total de clientes atendidos em 2006.

$\mathrm{Na}$ análise individual, por concessionária, observa-se tendência semelhante, sendo que no último ano da série histórica (2011), somente uma concessionária atendeu mais clientes que em 2006 (ALLMO), enquanto apenas duas apresentaram acréscimo no número de 
clientes na comparação 2002/2011 (MRS e ALLMO). Mais uma vez, o principal destaque negativo foi a TLSA, que atendeu menos empresas que o total atendido em 2002 durante todos os anos do período 2004-2011, sendo que em 2011 (35 clientes) o total de clientes foi de apenas 30\% do total atendido em 2002 (101 clientes).

Figura 10 - Ferrovias da antiga RFFSA: Índice da evolução do número de clientes, total e por concessionária - 2002 a 2011 - Ano-base: 2002

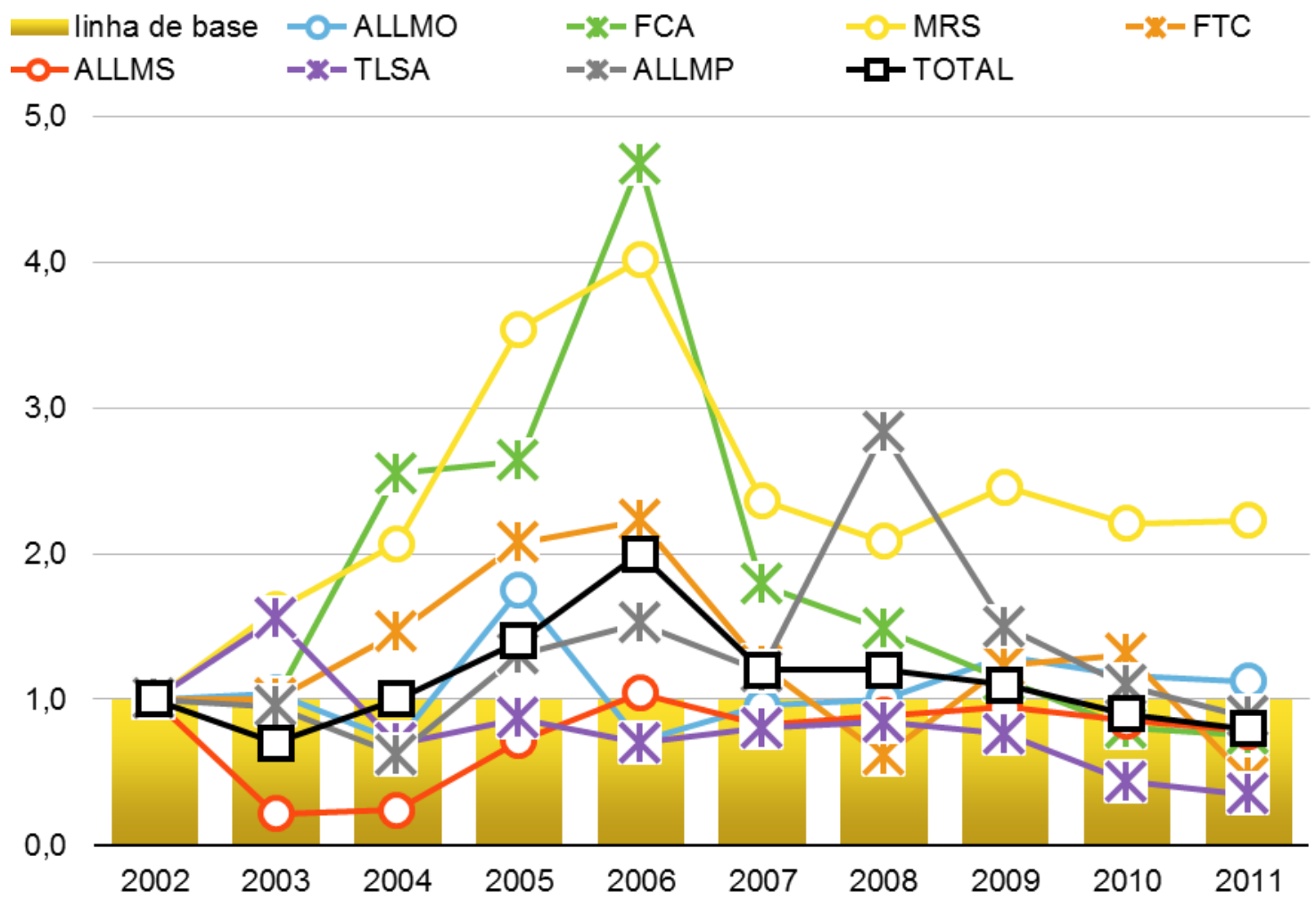

Fonte: ANTT (2014e)

Obs.: Ano-base: 2002 (índice 100)

\section{INVESTIMENTOS}

Conforme mencionado, o governo tinha como expectativa que a desestatização das malhas da antiga RFFSA conduzisse à ampliação do investimento na recuperação, modernização e ampliação da infraestrutura existente. 
$\mathrm{Na}$ Tabela 12 encontram-se relacionados os valores referentes ao investimento realizado pelas concessionárias das ferrovias da antiga RFFSA no período 2006-2013, por área de aplicação. No agregado, foram investidos R $\$ 17,15$ bilhões ${ }^{175}$, correspondente a uma média de $\mathrm{R} \$ 2,14$ bilhões por ano. Deste total, os investimentos em material rodante representaram 33,5\%, enquanto os recursos aplicados em via permanente, relativos à ampliação e melhoria da via existente, tiveram participação de, respectivamente, $32,6 \%$ e $18,5 \%$.

Cabe mencionar que os valores de investimento incluem os recursos relativos ao projeto da Ferrovia Nova Transnordestina pela TLSA. Caso não sejam considerados os valores associados ao referido projeto, o total investido no período se reduz para $\mathrm{R} \$ 12,50$ bilhões (equivalente a um investimento médio anual de $\mathrm{R} \$ 1,56$ bilhão). Da mesma forma, as participações por área de aplicação se alteram para: 46,0\% em material rodante e 33,0\% em melhorias ou ampliação da malha.

Desta forma, conclui-se que houve investimento significativo em material rodante $(\mathrm{R} \$$ 5,75 bilhões), favorecendo a indústria de equipamentos de transporte com a ampliação nas encomendas. Contudo, nota-se que os investimentos relativos à expansão e melhoria da infraestrutura ferroviária ( $\mathrm{R} \$ 4,13$ bilhões $^{176}$ ) foram, de certa forma, limitados, podendo ser entendidos como consequência do fato de os contratos não apresentarem mecanismos adequados de incentivo e "enforcement" para as concessionárias. Conforme afirma CAMPOS e CANTOS $(2000)^{177}$, a regulação da infraestrutura ferroviária deve incluir requisitos mínimos de investimento para compensar a miopia do curto-prazo, de forma a

\footnotetext{
${ }^{175}$ Em valores correntes.

${ }^{176}$ Investimento realizado no período 2006-2013, sem considerar o montante aplicado no projeto da Ferrovia Nova Transnordestina.

${ }^{177}$ CAMPOS e CANTOS (2000, p.43)
} 
garantir que os investimentos chave não estejam subordinados exclusivamente a metas privadas.

Tabela 12 - Ferrovias da antiga RFFSA: Investimento total, por área de aplicação (R \$ milhões, valores correntes) - 2006 a 2013

\begin{tabular}{|c|c|c|c|c|c|c|c|c|}
\hline Discriminação & 2006 & 2007 & 2008 & 2009 & 2010 & 2011 & 2012 & 2013 \\
\hline TOTAL & $1.106,6$ & $1.570,4$ & $2.186,0$ & $1.311,5$ & $2.855,3$ & $2.997,3$ & $2.760,8$ & $2.356,5$ \\
\hline $\begin{array}{l}\text { Material Rodante } \\
\text { (Vag/Loco/Outros } \\
\text { VeicEquip/Carro } \\
\text { Passag) }\end{array}$ & 375,3 & 741,6 & $1.265,3$ & 484,4 & 473,4 & $1.024,1$ & 738,8 & 647,8 \\
\hline Locomotiva & 193,6 & 359,0 & 763,7 & 253,8 & 210,9 & 610,3 & 504,2 & 307,4 \\
\hline Vagão & 166,1 & 357,9 & 482,7 & 206,9 & 240,8 & 394,9 & 204,7 & 227,2 \\
\hline $\begin{array}{l}\text { Outros veículos e } \\
\text { equipamentos }\end{array}$ & 15,6 & 24,7 & 18,9 & 23,8 & 21,8 & 19,0 & 29,9 & 113,2 \\
\hline Veículos Rodoviários & $\mathbf{0 , 3}$ & $\mathbf{0 , 0}$ & 0,5 & 0,1 & $\mathbf{0 , 1}$ & $\mathbf{0 , 1}$ & 3,4 & 6,4 \\
\hline Via Permanente & 504,2 & 492,6 & 676,5 & 669,6 & $2.068,5$ & $1.589,4$ & $1.569,9$ & $1.201,6$ \\
\hline Ampliação da Malha & 5,9 & 61,7 & 198,2 & 182,7 & $1.367,9$ & $1.431,4$ & $1.338,8$ & $1.008,0$ \\
\hline $\begin{array}{l}\text { - Implantação da Nova } \\
\text { Transnordestina }\end{array}$ & - & 39,3 & 172,9 & 151,0 & $1.302,3$ & $1.304,7$ & 847,3 & 825,2 \\
\hline - Demais & 5,9 & 22,4 & 25,2 & 31,7 & 65,6 & 126,7 & 491,5 & 182,7 \\
\hline Malha Existente & 498,3 & 430,8 & 478,3 & 486,9 & 700,6 & 158,0 & 231,2 & 193,6 \\
\hline Telecomunicações & 7,6 & 5,7 & 2,2 & 8,3 & 4,8 & 11,2 & 27,8 & 11,7 \\
\hline Sinalização & 33,7 & 54,6 & 57,9 & 22,5 & 31,0 & 47,6 & 126,1 & 21,9 \\
\hline Oficinas & 18,7 & 12,8 & 6,7 & $\mathbf{7 , 3}$ & 15,9 & 24,8 & 57,6 & 47,1 \\
\hline Capacitação & 11,9 & 14,1 & 18,0 & 15,4 & 24,0 & 19,4 & 23,2 & 12,0 \\
\hline Outros Investimentos & 154,9 & 249,1 & 158,9 & 104,0 & 237,6 & 280,7 & 214,1 & 408,1 \\
\hline Meio-ambiente & 4,5 & 7,4 & 9,9 & 8,4 & 11,4 & 18,7 & 14,6 & 5,1 \\
\hline Edificações & 11,8 & 47,3 & 11,4 & 4,0 & 63,4 & 52,9 & 25,2 & 53,1 \\
\hline Informatização & 18,0 & 21,7 & 14,6 & 50,6 & 38,4 & 41,2 & 30,6 & 32,1 \\
\hline Outros & 120,5 & 172,7 & 123,0 & 40,9 & 124,4 & 168,0 & 143,7 & 317,9 \\
\hline
\end{tabular}

Fonte: ANTT (2014e) 
Conforme assinalado, nos últimos anos, as concessionárias investiram significativamente em material rodante, totalizando $\mathrm{R} \$ 5,75$ bilhões no período 2006-2013. A Tabela 13 apresenta um comparativo relativo à quantidade de locomotivas e vagões em circulação, por concessionária, previamente às concessões e em 2013. Observa-se que entre os dois momentos considerados, houve um aumento de $65 \%$ no total de locomotivas, com 913 locomotivas adicionais em circulação, e 42\% de incremento no número de vagões, ampliando em 18.527 o número vagões em circulação em 2013, com relação à frota em operação previamente às concessões.

$\mathrm{Na}$ análise individual das concessionárias, pode-se observar que a FCA, a MRS e a ALLMS ampliaram suas frotas de locomotivas em mais de $120 \%$ e a de vagões em mais de 50\%. A ALLMP foi a única concessionária a reduzir tanto seu número de locomotivas como de vagões entre os dois momentos considerados. Outras duas concessionárias (a FTC e a ALLMO) diminuíram apenas a quantidade de vagões, ampliando, por outro lado, o número de locomotivas em circulação.

Tabela 13 - Ferrovias da antiga RFFSA: Material Rodante em circulação, total e por concessionária - Pré-concessão e 2013

\begin{tabular}{|c|c|c|c|c|c|c|c|c|c|}
\hline \multirow{3}{*}{$\begin{array}{l}\text { Malha } \\
\text { Oeste }\end{array}$} & \multirow{3}{*}{$\begin{array}{l}\text { Concessi } \\
\text { onária - } \\
\text { Denomin } \\
\text { ação } \\
\text { atual }\end{array}$} & \multicolumn{4}{|c|}{$\mathbf{N}^{0}$ de Locomotivas em circulação } & \multicolumn{4}{|c|}{$\mathbf{N}^{0}$ de Vagões em circulação } \\
\hline & & \multirow{2}{*}{$\begin{array}{r}2013 \\
80\end{array}$} & \multicolumn{2}{|c|}{ Pré-concessão } & \multirow{2}{*}{$\begin{array}{c}\begin{array}{c}\text { Var 2013/ } \\
\text { pré- } \\
\text { concessão } \\
(\%)\end{array} \\
18 \%\end{array}$} & \multirow{2}{*}{\begin{tabular}{|l}
2013 \\
2.560
\end{tabular}} & \multicolumn{2}{|c|}{ Pré-concessão } & \multirow{2}{*}{$\begin{array}{r}\begin{array}{c}\text { Var 2013/ } \\
\text { pré- } \\
\text { concessão } \\
(\%)\end{array} \\
-2 \%\end{array}$} \\
\hline & & & 68 & Jun/95 & & & 2.617 & Dez/93 & \\
\hline $\begin{array}{l}\text { Centro- } \\
\text { Leste }\end{array}$ & FCA & 615 & 268 & Dez/95 & $129 \%$ & 13.109 & 8.561 & Dez/95 & $53 \%$ \\
\hline Sudeste & MRS & 782 & 344 & Mar/96 & $127 \%$ & 19.363 & 10.530 & Mar/96 & $84 \%$ \\
\hline $\begin{array}{l}\text { Tereza } \\
\text { Cristina }\end{array}$ & FTC & 11 & 9 & $\mathrm{Jul} / 96$ & $22 \%$ & 372 & 401 & $\mathrm{Jul} / 96$ & $-7 \%$ \\
\hline Sul & ALLMS & 528 & 235 & $\begin{array}{c}\text { Jul- } \\
\text { Set/96 }\end{array}$ & $125 \%$ & 15.682 & 9.700 & $\begin{array}{c}\text { Jul- } \\
\text { Set/96 }\end{array}$ & $62 \%$ \\
\hline Nordeste & TLSA & 109 & 63 & Dez/96 & $73 \%$ & 1.840 & 1.780 & Dez/96 & $3 \%$ \\
\hline \multirow[t]{2}{*}{ Paulista } & ALLMP & 183 & 408 & Mar/98 & $-55 \%$ & 9.942 & 10.753 & Mar/98 & $-8 \%$ \\
\hline & TOTAL & 2.308 & 1.395 & & $65 \%$ & 62.868 & 44.342 & & $42 \%$ \\
\hline
\end{tabular}

Fonte: ANTT (2014e) 


\section{K. ALGUMAS CONCLUSÕES}

Em primeiro lugar, observa-se que os resultados obtidos com as concessões das malhas da antiga RFFSA não foram homogêneos. Enquanto algumas concessionárias alcançaram resultados extremamente positivos em termos de aumento de produção, ganhos de produtividade e redução de acidentes, o desempenho de outras evidenciou que a administração privada não representou necessariamente melhorias significativas nesses aspectos, comparando-se as situações pré e pós-concessão.

Ademais, verifica-se que tendo em consideração as expectativas que se tinha quando das concessões das malhas da antiga RFFSA, as principais limitações estão relacionadas a dois aspectos:

investimentos reduzidos na recuperação, modernização e ampliação da infraestrutura existente;

as ferrovias não se capacitaram para a operação de cargas não cativas do transporte ferroviário, não tendo sido verificada a ampliação de segmentos produtivos atendidos pelo modal ou o aumento da participação do transporte de carga geral por estas ferrovias.

Na próxima seção será caracterizado e analisado o modelo adotado na concessão das ferrovias da antiga RFFSA, em um intento de buscar identificar algumas das razões que conduziram aos resultados apontados. 


\subsubsection{O MODELO DE CONCESSÃO DAS MALHAS DA ANTIGA RFFSA}

Conforme descrito, os leilões de concessão das sete malhas ferroviárias que integraram a antiga RFFSA ocorreram no período compreendido entre março de 1996 e novembro de 1998, no marco da Lei de Concessões, sancionada em março de $1995^{178}$, da Lei 9.074, de julho do mesmo ano ${ }^{179}$ e do Regulamento dos Transportes Ferroviários ${ }^{180}$, aprovado na véspera da realização do primeiro leilão, relativo à Malha Oeste.

A estrutura escolhida contemplou o transporte de cargas como negócio, a subdivisão da RFFSA em um número limitado de "malhas regionais", a conservação da unicidade no âmbito de cada malha e a transferência de posse dos ativos, basicamente, por arrendamento. $^{181}$

As concessionárias destas malhas têm sob seu encargo, em caráter de exclusividade, a operação da via permanente, material rodante e demais ativos operacionais e de apoio afetos a cada malha, sendo verticalmente integradas. ${ }^{182}$ Ao mesmo tempo, ao atender diferentes regiões, pode-se dizer que essas concessionárias são separadas horizontalmente, ainda que tenham exclusividade na exploração e no desenvolvimento do transporte ferroviário de carga na faixa de domínio da malha sob sua responsabilidade.

\footnotetext{
${ }^{178}$ Lei no 8.987 , de 13/02/1995.

${ }^{179}$ A Lei n ${ }^{\circ}$ 9.074, de 07/07/1995, estabelece normas para outorga e prorrogações das concessões e permissões de serviços públicos e dá outras providências.

${ }^{180}$ Decreto no 1.832 , de 04/03/1996, que aprova o Regulamento dos Transportes Ferroviários (RTF).

${ }^{181}$ Decisão TCU 138/1996 - Ata 13/96.

${ }^{182}$ Cabe mencionar que a concessão da malha nordeste compreende também o direito de exploração da Ferrovia Transnordestina, uma vez que a mesma esteja efetivamente implantada. Neste caso, a concessionária tem prioridade na exploração da ferrovia, a partir do pagamento da outorga. A concessão da Ferrovia Transnordestina foi atribuída sob condição suspensiva cumulada com opção de desistência. A condição suspensiva isenta a concessionária de obrigações relacionadas à construção da mencionada ferrovia, sendo esta de responsabilidade da União. A opção é pela desistência da operação da ferrovia pela concessionária, sem ônus, assim que for notificada pela concedente sobre o preço mínimo para receber e operar os respectivos conjuntos de bens operacionais.
} 
Os editais de concessão não estabeleceram requisitos para a qualificação dos licitantes, prevendo apenas a limitação de participação de no máximo $20 \%$ por grupo econômico no controle de cada consórcio. O vencedor de cada leilão foi definido considerando-se como critério de julgamento a maior oferta econômica, conformada por três componentes: i) valor da concessão, correspondente a 5\% do total; ii) montante referente ao arrendamento e; iii) valor destinado à aquisição de bens de pequeno valor.

A avaliação econômico-financeira de cada malha foi efetuada com base no valor presente líquido do fluxo de caixa operacional projetado ${ }^{183}$, a partir do qual foi estabelecido o preço mínimo de outorga expresso nos editais ${ }^{184}$. Para tanto, a modelagem considerou uma taxa interna de retorno (TIR) real e de projeto variando entre 10 e $15 \%$ ao ano ${ }^{185}$ - atribuída conforme o risco envolvido em cada empreendimento - e prazo de concessão pelo período de 30 anos. Os contratos de concessão preveem a possibilidade de prorrogação por no máximo igual período, por interesse manifesto da concessionária e exclusivo critério do Poder Concedente, desde que a primeira "não tenha sido reincidente em condenação administrativa ou judicial por abuso de poder econômico e tenha atingido e mantido a prestação de serviço adequado" $^{186}$.

\footnotetext{
${ }^{183}$ Cf. art. 30 do Decreto no $1.204 / 1994$.

${ }^{184}$ O preço mínimo foi estabelecido considerando-se as estimativas de receita, custo e investimento.

${ }^{185}$ Malha Oeste: $12 \%$ a.a.; Malha Centro-Leste: $12 \%$ a.a. (Acórdão TCU n. 341, de 03/07/1996); Malha Sudeste: $10 \%$ a.a. (Acórdão TCU n. 559, de 24/09/1996); Tereza Cristina: $13 \%$ a.a. (Acórdão TCU n. 748, de 09/12/1996); Malha Sul: 12\% a.a. (Acórdão TCU n. 823, de 26/12/1996); Malha Nordeste: $15 \%$ a.a. (Acórdão TCU n. 621, de 02/10/1998); Malha Paulista: 12\% a.a. Cabe observar que as mencionadas taxas foram utilizadas exclusivamente para a definição dos preços mínimos considerados nos leilões.

${ }^{186}$ Cf. contratos de concessão. As condições que caracterizam o serviço adequado são: regularidade, continuidade, eficiência, segurança, atualidade, generalidade, cortesia na sua prestação e modicidade tarifária.
} 
Com relação às tarifas pela prestação do serviço de transporte ${ }^{187}$, os contratos dispõem que devem ser negociadas diretamente entre as administrações ferroviárias e os usuários ${ }^{188}$, de acordo com a natureza do transporte, estando limitadas por valores máximos denominadas tarifas de referência, que dependem de homologação do Poder Concedente -, e valores mínimos, que devem remunerar os custos variáveis de longo prazo. O estabelecimento de tarifas mínimas tem como objetivo garantir que o concessionário aufira receitas suficientes para cobrir os custos operacionais, favorecendo a continuidade da prestação do serviço $^{189}$, além de limitar a possibilidade de cobrança de tarifas menores de clientes pertencentes ao mesmo grupo econômico e de tarifas maiores de empresas vinculadas a grupos concorrentes, por meio de subsídio cruzado ${ }^{190}$.

Para fins de preservação do equilíbrio econômico-financeiro ${ }^{191}$, os contratos preveem três mecanismos de alteração tarifária:

- reajustes anuais pela variação do IGP-DI da Fundação Getúlio Vargas;

- revisões ordinárias, a cada cinco anos, por determinação do Poder Concedente;

- revisões extraordinárias, a qualquer tempo e por solicitação da concessionária, em caso de alteração justificada de mercado e/ou custos de caráter permanente. ${ }^{192}$

\footnotetext{
${ }^{187}$ Cf. contratos de concessão, para usuários dependentes do transporte ferroviário, as tarifas devem ser estabelecidas por meio de contrato voluntário para o estabelecimento de tarifas. Em caso de falta de acordo e por solicitação do usuário, está prevista a fixação de tarifas específicas pelo Poder Concedente.

${ }^{188}$ Cf. previsto no $\S 1^{\circ}$ do art. 17 Decreto $n^{\circ} 1.832 / 1996$.

${ }^{189}$ Cf. ESTACHE, GOLDSTEIN e PITTMAN (2001, p.15), por meio de intervenção política, motivada pela contenção inflacionária e provisão de serviço de caráter universal, as tarifas praticadas pela RFFSA eram muitas vezes inferiores ao mínimo necessário para cobrir os custos variáveis.

190 Idem.

${ }^{191} \mathrm{O} \$ 4^{\circ}$ do art. $9^{\circ}$ da Lei 8.987/1995, determina que "Em havendo alteração unilateral do contrato que afete o seu inicial equilíbrio econômico-financeiro, o poder concedente deverá restabelecê-lo, concomitantemente à alteração".

192 Os contratos não preveem explicitamente as regras de alocação de riscos entre o concedente e a concessionária. Da mesma forma, não há regulamentação que caracterize enquadramento à condição de "alteração justificada de mercado".
} 
De forma complementar, as concessionárias podem cobrar taxas adicionais ${ }^{193}$ dos usuários referentes a operações acessórias à realização do transporte - tais como: carga, descarga, transbordo, estadia, armazenagem, manobra e manutenção de material rodante. Sem embargo, de acordo com o Regulamento dos Usuários dos Serviços de Transporte Ferroviário de Cargas (Resolução ANTT n 3.694/2011), os usuários podem realizar as operações acessórias por meios próprios ou mediante a contratação de terceiros.

Os contratos também preveem o monitoramento da qualidade dos serviços prestados pelo concedente. Para tanto, foram expressas nos contratos metas anuais de produção de transporte e de segurança operacional (redução do índice de acidentes) para os cinco ${ }^{194}$ primeiros anos de concessão, que a cada quinquênio subsequente devem ser pactuadas em conjunto com as concessionárias.

Cabe mencionar que a aplicação de penalidades pelo não cumprimento de metas de produção e redução de acidentes no âmbito dos contratos de concessão do transporte ferroviário de cargas foi regulamentada apenas sete anos após a realização das três primeiras outorgas das malhas da antiga RFFSA, por meio da Resolução ANTT $\mathrm{n}^{\mathrm{o}}$ 288, de $10 / 09 / 2003^{195}$.

Dentre outras obrigações das concessionárias previstas nos contratos de concessão, destacam-se:

- prestar serviço adequado ao pleno atendimento dos usuários, sem qualquer tipo de discriminação e sem incorrer em abuso de poder econômico, atendendo às condições de

\footnotetext{
${ }^{193}$ Cf. previsto no art. 18 do Decreto no $1.832 / 1996$.

${ }^{194}$ Sendo três primeiros anos para as metas de produção da Malha Paulista, cf. contrato de concessão.

${ }^{195}$ Conforme o disposto no regulamento, o não cumprimento de uma das duas metas é passível de advertência. Em caso de reincidência por dois ou mais exercícios, consecutivos ou intermitentes, pelo período de até 6 anos, ou em caso de a concessionária não cumprir ambas as metas em um único exercício, a multa é aplicada, em valor equivalente a percentual entre $0,1 \%$ e $2,0 \%$ da receita anual bruta de transporte, sendo o percentual definido conforme o grau de reincidência.
} 
regularidade, continuidade, eficiência, segurança, atualidade, generalidade, cortesia na sua prestação e modicidade tarifária ${ }^{196} ;{ }^{197}$

- garantir tráfego mútuo ou, no caso de sua impossibilidade, permitir o direito de passagem a outros operadores ferroviários ${ }^{198}$, mediante a celebração de contrato ${ }^{199} ; 200$

- dar, anualmente, conhecimento prévio à concedente de plano trienal de investimentos visando ao alcance das metas contratuais, indicando projetos, custos e cronograma de implantação.

- manter a continuidade do serviço concedido, salvo interrupção emergencial causada por caso fortuito ou força maior, comunicando imediatamente a ocorrência de tais fatos à Concedente. ${ }^{201}$

- prover todos os recursos necessários à exploração da concessão por sua conta e risco exclusivos.

\footnotetext{
${ }^{196}$ Replica o que prevê o art. $6^{\circ}, \S 1^{\circ}$, da Lei n ${ }^{\circ} 8.987 / 95$ : “Toda concessão ou permissão pressupõe a prestação de serviço adequado ao pleno atendimento dos usuários, conforme estabelecido nesta Lei, nas normas pertinentes e no respectivo contrato; $\S 1^{\circ}$ Serviço adequado é o que satisfaz as condições de regularidade, continuidade, eficiência, segurança, atualidade, generalidade, cortesia na sua prestação e modicidade das tarifas."

${ }^{197}$ O art.18 da Resolução ANTT n ${ }^{\circ}$ 3.694/2011 estabelece os requisites de qualidade que devem ser previstos na prestação do serviço de transporte ferroviário de cargas, definindo: I - regularidade: manutenção da prestação do serviço de transporte segundo os padrões técnicos e operacionais; II - continuidade: não interrupção da prestação dos serviços de transporte e operações acessórias assumidas pela concessionária; III - segurança: atendimento às condições e às normas de segurança inerentes à prestação do serviço de transporte, inclusive em relação a terceiros; IV - atualidade: modernização constante de técnicas e bens necessários à prestação do serviço de transporte, bem como da melhoria e expansão do serviço; V - generalidade: preservação da liberdade de acesso dos usuários aos serviços de transporte ferroviário de cargas e operações acessórias necessárias à execução daquele; VI - pontualidade: cumprimento dos prazos estabelecidos; VII - transparência na gestão: garantia da prestação de informações e tratamento adequado das denúncias referentes à prestação dos serviços de transporte; e VIII - modicidade: cobrança de tarifas que observem o equilíbrio entre custos da prestação do serviço de transporte e benefícios oferecidos aos usuários.

${ }^{198}$ Cf. art. $6^{\circ}$ do Decreto ${ }^{\circ} 1.832 / 1996$.

${ }^{199}$ Denominado Contrato Operacional Específico (COE) cf. art. $6^{\circ}$ da Resolução ANTT n ${ }^{\circ}$ 3.695/2011.

${ }^{200}$ Não está prevista aplicação de penalidade em caso de descumprimento.

${ }^{201}$ Não está prevista aplicação de penalidade em caso de descumprimento.
} 
Vinculados aos contratos de concessão, foram firmados, simultaneamente e por igual período, contratos de arrendamento dos bens operacionais de propriedade da União. Dentre os ativos operacionais arrendados, incluem-se: estações, pátios, trilhos, dormentes, vagões, locomotivas, armazéns e escritórios. Os contratos de arrendamento representam a maior parcela dos valores de outorga pagos pelas empresas concessionárias, equivalente a percentual variando entre $86,3 \%$ a $94,6 \%$ da outorga, conforme a malha.

Segundo a OECD (2013) ${ }^{202}$, as ferrovias demandam investimentos elevados e regulares para garantir a qualidade e a segurança da infraestrutura, mas a privatização e a concorrência podem afetar os incentivos e a capacidade de garantir os níveis necessários de investimento. De fato, esta é a situação que se observa em algumas das ferrovias da antiga RFFSA, conforme apresentado na seção anterior.

No entanto, ainda que seja uma consequência inerente ao processo, permite-se supor que alguns elementos contratuais favoreceram esta condição. Nota-se que os contratos de concessão das ferrovias da antiga RFFSA não definem, de forma explícita, obrigações de investimento nas malhas por parte das concessionárias, estando estas implicitamente associadas ao cumprimento de metas de produção e segurança operacional. Conforme mencionado, autores como CAMPOS e CANTOS (2000) recomendam que os contratos de concessão que envolvam a exploração da infraestrutura prevejam os investimentos mínimos necessários.

Pelo modelo adotado, esperava-se que os investimentos em infraestrutura ferroviária ocorreriam como resultado do "esforço" das concessionárias em garantir o cumprimento das metas contratuais. No entanto, conforme ressaltado, a aplicação de penalidades pelo não cumprimento de metas foi regulamentada apenas em 2003. Além da falta de regulamentação, identificam-se outros elementos do modelo que denotam limitações do mecanismo de $202 \operatorname{OECD}(2013$, p.9) 
incentivo ao incremento do investimento. Como exemplo pode-se citar o fato de que até 2011 as metas de produção eram estabelecidas por malha, possibilitando que a concessionária investisse seletivamente em certos trechos, uma vez que a operação eficiente em alguns segmentos garantia o cumprimento às metas estabelecidas.

Pode-se inferir, ademais, que a falta de investimento pode ter afetado a ampliação de segmentos produtivos atendidos pelas malhas ferroviárias concedidas, em função da baixa performance na prestação do serviço e da oferta de capacidade operacional insuficiente. Sobretudo para embarcadores de produtos de maior valor agregado, a confiabilidade e a eficiência na prestação do serviço são fatores essenciais. Neste sentido, a migração do transporte rodoviário para o ferroviário pressuporia além de tarifas mais competitivas, a introdução de melhorias na qualidade do serviço prestado aos usuários.

Outro aspecto que cabe menção diz respeito à criação da Agência Nacional de Transportes Terrestres (ANTT) - responsável pela regulação das concessões ferroviárias, mais de cinco anos após as primeiras outorgas de concessão das malhas da RFFSA, por meio da Lei $\mathrm{n}^{\mathrm{o}}$ 10.233/2001. Fazendo um paralelo com os setores de energia e telefonia, observa-se que, diferentemente do caso da ANTT, as respectivas agências reguladoras surgiram ao mesmo tempo em que se dava a desestatização desses serviços públicos (OJIMA e COMITRE, 2008) ${ }^{203}$. Considerando-se que a atuação regulatória ocorre antes e após a outorga de concessões, observa-se que no caso brasileiro o início da atuação da ANTT se deu em um contexto em que a agência não pôde participar da negociação das regras estabelecidas nos contratos de concessão das ferrovias da antiga RFFSA.

Cabe assinalar, contudo, que a aprovação do novo marco regulatório do setor ferroviário representa expectativas positivas ao desenvolvimento do setor. Em julho de 2011, a ANTT aprovou três regulamentos que constituem as bases deste novo marco regulatório:

\footnotetext{
${ }^{203}$ OJIMA e COMITRE (2008, p.4)
} 
'Regulamento das Operações de Direito de Passagem e Tráfego Mútuo'; 'Regulamento para pactuar as metas de produção por trecho e as metas de segurança para as concessionarias de serviço público de transporte ferroviário de cargas'; e 'Regulamento dos Usuários dos Serviços de Transporte Ferroviário de Cargas'. Neste contexto, destacam-se dois aspectos que podem ser compreendidos como incentivos à ampliação do investimento nas malhas ferroviárias concedidas, bem como ao aumento de segmentos produtivos atendidos: as 'operações de tráfego mútuo e direito de passagem' e o 'usuário investidor'.

\section{OPERAÇÕES DE TRÁFEGO MÚTUO E DIREITO DE PASSAGEM E USUÁRIO INVESTIDOR}

Conforme mencionado, os contratos preveem que as concessionárias devem garantir o acesso a suas malhas a operadores concorrentes. ${ }^{204}$

A Tabela 14 apresenta a produção de transporte realizada em tráfego mútuo e direito de passagem no período 2004-2008. Apesar de comporem os princípios do processo de desestatização do setor ferroviário, estando previstas desde antes da outorga das concessões, verifica-se que as operações de compartilhamento de infraestrutura ferroviária e recursos operacionais são ainda restritas. Conforme se observa, do total produzido pelas malhas que integraram a antiga RFFSA, apenas $12 \%$ envolveu a utilização de trechos em mais de uma malha no ano de 2008.

Tabela 14 - Ferrovias da antiga RFFSA: Produção em Tráfego Mútuo (TM) e Direito de Passagem (DP), em bilhões de TKU, por malha receptora - 2004 a 2008

\begin{tabular}{lllllll}
$\begin{array}{l}\text { Malha } \\
\text { receptora }\end{array}$ & $\begin{array}{l}\text { Concessionária - } \\
\text { Denominação } \\
\text { atual }\end{array}$ & $\mathbf{2 0 0 4}$ & $\mathbf{2 0 0 5}$ & $\mathbf{2 0 0 6}$ & $\mathbf{2 0 0 7}$ & $\mathbf{2 0 0 8}$ \\
\hline Oeste & ALLMO & 219,0 & 218,8 & 327,8 & 301,5 & 253,7
\end{tabular}

\footnotetext{
${ }^{204}$ Este dispositivo é observado no art. $6^{\circ}$ do 'Regulamento dos Transportes Ferroviários' (Decreto n ${ }^{\circ}$ 1.832/1996), que determina que as “Administrações Ferroviárias são obrigadas a operar em tráfego mútuo ou, no caso de sua impossibilidade, permitir o direito de passagem a outros operadores”.
} 


\begin{tabular}{|c|c|c|c|c|c|c|}
\hline Centro-Leste & FCA & $7.169,0$ & $6.769,9$ & $3.198,4$ & $2.070,9$ & 806,6 \\
\hline Sudeste & MRS & $1.063,0$ & 648,0 & 818,2 & 902,9 & 841,6 \\
\hline $\begin{array}{l}\text { Tereza } \\
\text { Cristina }\end{array}$ & FTC & - & - & - & - & - \\
\hline Sul & ALLMS & 417,0 & 152,7 & 677,7 & 430,0 & 539,6 \\
\hline Nordeste & TLSA & 18,0 & 23,5 & - & - & 11,5 \\
\hline Paulista & ALLMP & $2.961,0$ & $6.750,6$ & $6.130,0$ & $7.562,3$ & $9.038,5$ \\
\hline \multicolumn{2}{|c|}{ TOTAL EM TM + DP } & $12.170,0$ & $11.847,00$ & $14.563,50$ & $11.152,14$ & $11.267,57$ \\
\hline \multicolumn{2}{|c|}{$\begin{array}{l}\text { \% SOBRE PRODUÇÃO } \\
\text { TOTAL }\end{array}$} & $15 \%$ & $14 \%$ & $17 \%$ & $13 \%$ & $12 \%$ \\
\hline
\end{tabular}

Até 2011, as operações de tráfego mútuo e direito de passagem eram disciplinadas pela Portaria MT no 10/2000, que aprova a Norma Complementar no 04/2000, substituída pelas Resoluções ANTT n ${ }^{\circ}$ 433/2004 e 895/2005. A Resolução ANTT nº 3.695/2011 revogou as normas anteriores e aprovou o 'Regulamento das Operações de Direito de Passagem e Tráfego Mútuo', que dispõe sobre os procedimentos relativos ao compartilhamento de infraestrutura ferroviária e de recursos operacionais visando à integração operacional do Sistema Ferroviário Nacional. Por meio de seu art. $2^{\circ}$, o referido regulamento estabeleceu novas definições para os conceitos de tráfego mútuo e direito de passagem, quais sejam:

- Tráfego mútuo: “operação em que uma concessionária compartilha com outra concessionária, mediante pagamento, via permanente ${ }^{205}$ e recursos operacionais para prosseguir ou encerrar a prestação de serviço público de transporte ferroviário de cargas”.

- Direito de passagem: “operação em que uma concessionária, para deslocar a carga de um ponto a outro da malha ferroviária federal, utiliza, mediante pagamento, via

\footnotetext{
${ }^{205}$ Cf. KLINCEVICIUS (2011), "via permanente é a denominação utilizada para o conjunto de camadas e de elementos que possibilitam a passagem de trens. Os componentes da via permanente são a infraestrutura e a superestrutura". No Brasil, a infraestrutura se refere à camada inferior de terraplenagem, chamada de subleito ou plataforma, enquanto a superestrutura é composta pelos trilhos, fixações, dormentes, lastro e sublastro.
} 
permanente e sistema de licenciamento de trens da concessionária em cuja malha dar-se-á parte da prestação de serviço".

A condição que caracteriza a impossibilidade de tráfego mútuo foi definida pelo art. $3^{\text {o }}$ do mesmo regulamento: a impossibilidade de tráfego mútuo ocorre quando houver desacordo comercial entre as partes ou em caso de restrições operacionais que comprometam o atendimento eficiente da necessidade de transporte - por exemplo, quando a transferência de carga de uma operadora para outra se tornar excessivamente cara. Neste contexto, o dispositivo prevê o compartilhamento da infraestrutura, devendo a tarifa ser negociada entre a concessionária e a empresa requerente. Inexistindo acordo, a ANTT deverá arbitrar o valor a ser pago.

$\mathrm{O}$ art. $9^{\circ}$ do 'Regulamento para pactuar as metas de produção por trecho e as metas de segurança para as concessionarias de serviço público de transporte ferroviário de cargas' (Resolução ANTT n 3.696/2011) impõe que a concessionária deverá disponibilizar toda a capacidade ociosa da malha sob sua responsabilidade, inclusive para operações de tráfego mútuo ou direito de passagem.

A informação sobre a existência de capacidade ociosa, trecho a trecho, pode ser conhecida por meio da 'Declaração de Rede', instrumento de gerenciamento da capacidade das malhas ferroviárias, que consolida características técnicas e operacionais que devem ser fornecidas anualmente pelas concessionárias acerca da malha sob sua responsabilidade. ${ }^{206}$

Como forma de incentivar a ampliação de operações de direito de passagem e tráfego mútuo, a Resolução ANTT n ${ }^{0}$ 3.696/2011 disciplina a associação da produção vinculada a operações desta natureza à produção da concessionária detentora do trecho, para fins de avaliação do cumprimento das metas de produção.

\footnotetext{
${ }^{206}$ Cf. disposto no art. $5^{\circ}$ da Resolução ANTT n ${ }^{0} 3.696 / 2011$.
} 
Para os trechos em que não houver capacidade ociosa, as operações em tráfego mútuo ou direito de passagem podem ensejar a realização de investimentos de expansão. Neste contexto, a Resolução ANTT $n^{0} 3.695 / 2011$ prevê que esses investimentos poderão ser suportados pela concessionária detentora da via ou por aquela que solicita o compartilhamento de infraestrutura ferroviária e/ou de recursos operacionais, mesmo que a mesma não utilize toda a capacidade adicional ${ }^{207}$. No primeiro caso, a detentora do trecho poderá exigir cláusula de demanda firme, contendo prazos e taxas de retorno compatíveis à recuperação dos investimentos realizados, respeitado o prazo final da concessão. No segundo, os investimentos suportados deverão ter o seu retorno atrelado à utilização da infraestrutura ferroviária.

Adicionalmente, a Resolução ANTT $\mathrm{n}^{\mathrm{o}}$ 3.695/2011 disciplina as regras que possibilitam ao usuário, visando o transporte de carga própria, investir na aquisição de material rodante ou realização de obras de expansão ou recuperação da malha ferroviária existente, podendo negociar mecanismo de compensação financeira com a concessionária detentora do trecho.

Pode-se verificar nestes dispositivos o princípio de alinhamento de incentivos, tanto no caso de investimentos suportados pela concessionária requerente como no caso de usuário investidor, de forma que os investimentos são custeados pela parte que demanda a sua realização.

\footnotetext{
${ }^{207}$ Neste caso, a capacidade ociosa resultante poderá ser negociada conforme as regras previstas.
} 


\section{O NOVO MODELO BRASILEIRO DE EXPLORAÇÃO FERROVIÁRIA}

O terceiro ciclo de concessões ferroviárias considerado neste trabalho se refere ao conjunto de ferrovias a ser licitado no âmbito do Programa de Investimentos em Logística (PIL). Em agosto de 2012, o governo federal lançou o PIL, contemplando projetos nas áreas de rodovias e ferrovias a serem implementados por meio de parcerias estratégicas com o setor privado. Em dezembro do mesmo ano, o programa foi estendido aos setores portuário e aeroportuário.

Para o setor ferroviário, o programa tem como objetivos principais a provisão de um sistema ferroviário amplo, moderno e integrado, cadeias de suprimentos eficientes e modicidade tarifária. Neste contexto, está prevista a concessão de, aproximadamente, 11 mil quilômetros de linhas férreas, que, em sua maior parte, deverão ser construídas pelo concessionário até o quinto ano do prazo contratual.

\subsection{SEPARAÇÃO VERTICAL COM "OPEN ACCESS" NO BRASIL}

As próximas concessões ferroviárias serão outorgadas no marco de um novo modelo de exploração, que apresenta como principais características a separação vertical entre a gestão dos trilhos e a prestação de serviços de transporte ferroviário e o livre acesso ("open access") de operadores a todas as malhas que compõem o Subsistema Ferroviário Nacional. Neste contexto, as concessões estarão restritas à gestão dos trilhos. Segundo o governo, a implementação deste novo modelo tem como objetivo central fomentar o setor ferroviário por meio da quebra de monopólio e a ampliação do acesso ao modal.

Cumpre mencionar que para alguns autores a separação vertical como mecanismo para viabilizar a concorrência intramodal não é tida como a melhor solução. Para PINHEIRO (2014), por exemplo, “os problemas que as reformas introduzem são muito maiores do que os que ela visa resolver" e "há instrumentos alternativos, com recurso ao sistema de defesa da 
concorrência, que podem ajudar a lidar com essa questão com efeitos colaterais muito mais brandos". De fato, como visto em seção anterior deste trabalho, a separação vertical com "open access" normalmente introduz problemas de coordenação, que são mais críticos em vias que apresentam maiores níveis de tráfego e necessidades de investimento na infraestrutura. Por outro lado, com base na experiência e literatura internacionais, entende-se que há evidências de que os benefícios superam os custos, e que a separação vertical pode ser conveniente para o caso brasileiro a depender do quão profunda ela seja.

A política de separação vertical e livre acesso ao subsistema ferroviário federal foi instituída no país por meio do Decreto nº 8.129/2013 e está voltada ao desenvolvimento do setor e à promoção de competição entre operadores ferroviários. De acordo com o Art. $1^{\circ}$ do referido Decreto, as novas concessões de infraestrutura ferroviária serão outorgadas segundo as seguintes diretrizes:

"I - separação entre as outorgas para exploração da infraestrutura ferroviária e para a prestação de serviços de transporte ferroviário;

II - garantia de acesso aos usuários e operadores ferroviários a toda malha integrante do Subsistema Ferroviário Federal;

III - remuneração dos custos fixos e variáveis da concessão para exploração da infraestrutura; $e$

IV - gerenciamento da capacidade de transporte do Subsistema Ferroviário Federal pela Valec Engenharia, Construções e Ferrovias S.A., inclusive mediante a comercialização da capacidade operacional de ferrovias, próprias ou de terceiros."

Conforme se observa, essas diretrizes estão amparadas pela Lei ${ }^{0} 10.233 / 2001$, após modificações introduzidas pela Lei ${ }^{0}{ }^{12.815 / 2013}$, considerando-se os pontos a seguir:

Inciso I do Art. 14 - Depende de concessão: a) a exploração das ferrovias que compõem a infraestrutura do Sistema Nacional de Viação; b) o transporte ferroviário de passageiros e cargas associado à exploração da infraestrutura ferroviária. 
- $\quad$ Inciso III do Art. 14 - Depende de autorização: f) o transporte ferroviário não regular de passageiros, não associado à exploração da infraestrutura; i) o transporte ferroviário de cargas não associado à exploração da infraestrutura, por operador ferroviário independente.

Inciso IV, b) do Art. 14 - Depende de permissão o transporte ferroviário regular de passageiros não associado à exploração da infraestrutura.

- $\quad$ Regulação dos procedimentos e condições de acesso: Inciso VIII do Art. 25 Cabe à ANTT regular os procedimentos e as condições para cessão a terceiros de capacidade de tráfego disponível na infraestrutura ferroviária explorada por concessionários.

Neste marco, as novas concessionárias (denominadas 'concessionárias horizontais' ${ }^{208}$ ) serão os gestores da infraestrutura (GIFs) e ficarão a cargo do investimento na via permanente e nos sistemas de sinalização e comunicação, manutenção, e controle do tráfego de composições ferroviárias, enquanto os operadores ferroviários - Concessionárias verticalmente integradas (denominadas 'concessionárias verticais' 209 ), Operadores Ferroviários Independentes (OFIs) ${ }^{210}$ ou Operadores de Transporte Multimodal (OTMs) serão responsáveis pela provisão de serviços de transporte ferroviário. Cabe notar que a separação vertical se dará com a atuação de empresas distintas na exploração da infraestrutura e na prestação de serviços de transporte ferroviário, todavia, sem a exigência de

\footnotetext{
${ }^{208}$ Cf. o Regulamento do Operador Ferroviário Independente (Resolução ANTT no 4.348, de 05/06/2014), concessionária horizontal é a "pessoa jurídica detentora do direito de exploração da infraestrutura ferroviária à qual é vedada a prestação do serviço de transporte ferroviário de cargas nos termos do respectivo contrato de concessão".

${ }^{209}$ Cf. o Regulamento do Operador Ferroviário Independente (Resolução ANTT no 4.348, de 05/06/2014), concessionária vertical é a "pessoa jurídica detentora do direito de exploração da infraestrutura ferroviária, incluído, nos termos constantes do respectivo contrato de concessão, qualquer direito relacionado à prestação dos serviços de transporte ferroviário de cargas".

${ }^{210}$ Cf. art. 13, parágrafo único da Lei $n^{\circ} 10.233 / 2001$. A Lei $n^{\circ} 12.743 / 2012$, promoveu, entre outras disposições, alterações à Lei 10.233/2001, definindo como operador ferroviário independente "a pessoa jurídica detentora de autorização para transporte ferroviário de cargas desvinculado da exploração da infraestrutura”.
} 
separação institucional, nos termos discutidos na seção 2.2 deste trabalho. Conforme minuta de contrato de concessão divulgada pela ANTT, o modelo prevê restrição de a concessionária deter qualquer participação societária em pessoa jurídica que realize serviço de transporte ferroviário, contudo, não há menção acerca de restrição com relação aos controladores.

Além de vedação relativa à exploração da atividade de operação e manutenção de trens, a 'concessionária horizontal' também estará impedida de prestar serviços de armazenagem, estadia e outras atividades relacionadas à exploração de polos e terminais logísticos ${ }^{211}$.

Os OFIs, que serão os operadores entrantes ${ }^{212}$, irão prover o material rodante e a operação das composições. Para atuar como OFI, as empresas deverão receber a outorga do serviço de transporte ferroviário de cargas não associado à exploração de infraestrutura ferroviária, por meio de autorização ${ }^{213}$ a ser expedida pela ANTT a todas as empresas que preencham os requisitos jurídicos, fiscais, econômico-financeiros e técnicos. Os requisitos econômico-financeiros incluem a apresentação de termo de compromisso de contratação de seguros de responsabilidade civil do transportador ferroviário de cargas, de responsabilidade civil geral e de riscos operacionais. No que concerne à habilitação técnica, ela será verificada mediante a apresentação de Termo de Compromisso de Qualificação Técnica, que deverá conter, entre outros: Termo de Compromisso de Contratação de Pessoal Técnico; descrição da frota a ser utilizada na prestação dos serviços, contendo as características técnicas relevantes em termos de operação, manutenção e segurança. De todo modo, o detalhamento

\footnotetext{
${ }^{211}$ Não está claro que o impedimento do exercício destas atividades possa ser uma medida que favoreça a eficiência do modelo. Uma alternativa seria o estabelecimento de regras para impedir o tratamento discriminatório entre diferentes operadores ferroviários, bem como de limitações em termos de controle acionário.

${ }^{212}$ No modelo brasileiro, consideram-se como operadores incumbentes as concessionárias verticalmente integradas, as "concessionárias verticais".

${ }^{213}$ O Regulamento do OFI dispõe que as autorizações serão outorgadas aos operadores por prazo indeterminado, condicionado ao recadastramento a cada 5 anos.
} 
dos requisitos, que ainda serão objeto de regulamentação, deverá considerar por um lado o alinhamento de incentivos para a cooperação GIF/OFI, e, por outro, a não introdução de barreiras à entrada de novos "players" no mercado.

PINHEIRO (2014) destaca que uma das fragilidades do novo modelo estaria associada à existência de pelo menos dois tipos de internalidades ${ }^{214}$ negativas entre a concessionária - detentora dos trilhos - e os OFIs. O primeiro advém da percepção de que o custo privado de interrupção do tráfego para um operador independente (interrupção provocada, por exemplo, pela ocorrência de um acidente ou quebra de composição) pode ser inferior ao custo socialmente ótimo associado. O segundo problema decorreria da não alocação ótima de investimentos entre a via e o equipamento rodante, dado que o OFI tenderia a investir em nível subótimo na qualidade do equipamento, por não internalizar o efeito de suas ações sobre a qualidade/manutenção da infraestrutura. Pode-se entender que ambos os problemas serão minimizados ${ }^{215}$ pelas disposições constantes no regulamento do operador ferroviário independente ${ }^{216}$, especialmente nos seguintes pontos: obrigação de estabelecimento pela concessionária de requisitos técnicos ${ }^{217}$ de utilização da infraestrutura ferroviária; exigências ao OFI de criação e manutenção de cadastro de material rodante utilizado na prestação do serviço e o registro do histórico de manutenções dos últimos 5 anos de operação, bem como de certificação, garantia e manutenção da qualidade do material rodante utilizado e de certificação de maquinistas que irão operar em cada concessionária, além da necessidade de contratação de seguros, conforme já mencionado. Da mesma forma,

\footnotetext{
${ }^{214}$ Cf. Spulber (apud PINHEIRO, 2014), internalidade pode ser definida como "custos ou benefícios de uma transação experimentados entre as partes que não estão considerados nos termos de troca estipulados para dita transação".

${ }^{215}$ Isso porque se referem a aspectos objetivos e verificáveis.

${ }^{216}$ Resolução ANTT n $^{\circ} 4.348 / 2014$.

${ }^{217}$ Cf. o Regulamento do Operador Ferroviário Independente, os referidos aspectos técnicos devem incluir: carga máxima permitida nas vias; exigências técnicas quanto ao material rodante que poderá ser utilizado pelo OFI; requisitos de treinamento, certificação e habilitação dos maquinistas, etc.
} 
como será apresentado mais adiante, a remuneração da 'concessionária horizontal' estará vinculada à efetiva disponibilização de capacidade operacional da ferrovia, sendo este um incentivo para que o GIF mantenha a via em boas condições de uso e, portanto, se interesse pela garantia do atendimento aos requisitos técnicos mínimos relativos ao material rodante e à contratação de seguros pelos operadores.

Outra característica do modelo diz respeito ao direito de acesso dos operadores ferroviários às malhas que integram o Subsistema Ferroviário Federal, incluindo vias concedidas sob diferentes modelos de exploração. Neste contexto, o regime de "open access" requererá que as concessionárias permitam o acesso equitativo, transparente e não discriminatório à via permanente a múltiplos operadores, em condições comerciais comparáveis àquelas aplicáveis em um mercado competitivo.

O tratamento não discriminatório pressupõe independência na alocação da capacidade de transporte das ferrovias. Para tanto, o governo atribuiu à estatal Valec - Engenharia, Construções e Ferrovias S.A. a responsabilidade de vender o direito de uso da capacidade de transporte das ferrovias exploradas por terceiros ${ }^{218}$ e de "planejar, administrar e executar os programas de exploração da capacidade de transporte das ferrovias das quais detenha o direito de uso"219, adotando a separação completa das atividades essenciais (alocação de capacidade e cobrança de tarifas de acesso à infraestrutura), nos moldes do padrão encontrado em países como Suíça e Hungria ${ }^{220}$. Observa-se que a forma de implementação da separação das atividades essenciais escolhida pelo governo brasileiro prescinde da regulação como mecanismo alternativo, tendo em vista a opção pela atuação estatal.

\footnotetext{
${ }^{218}$ Inciso II do Art. $3^{\circ}$ do Decreto no 8.129, de 23/10/2013.

${ }^{219}$ Inciso I do Art. $3^{\circ}$ do Decreto no 8.129 , de 23/10/2013.

${ }^{220}$ Cf. VAN DE VELDE et al. (2012, p.129), na Lituânia as ferrovias são controladas por uma estatal monolítica, e desde 2007, em regime de “open access" para operadores independentes. Para favorecer o tratamento não discriminatório, as atividades essenciais foram delegadas à uma entidade estatal. No entanto, o mercado não atraiu operadores entrantes até o momento.
} 
Deste modo, a Valec irá adquirir das 'concessionárias horizontais' a integralidade da capacidade operacional disponível, além de capacidade ociosa das malhas geridas pelas “concessionárias verticais ${ }^{221}$. Cabe notar que a estatal atuará como "one stop shop" na venda de acesso a malhas exploradas por diferentes concessionários, favorecendo a redução dos custos transacionais. ${ }^{222,223}$

Observa-se que no caso das novas concessões, a designação da Valec como responsável pela alocação de capacidade das ferrovias elimina os riscos potenciais de discriminação no acesso à infraestrutura a operadores entrantes. Como consequência, a imposição de restrição à prestação do serviço de transporte aos novos concessionários ferroviários perde a sua principal motivação pelo fato de a garantia de não discriminação já ser proporcionada pela presença da Valec. Por essa lógica, uma alternativa que poderia ser explorada nas novas concessões seria aceitar que a concessionária possa ser verticalmente integrada (caso queira) nos casos em que a Valec (ou outra instituição neutra) assuma a alocação de capacidade. Não seriam necessárias mudanças com relação ao regime de “open access". De toda forma, caberia analisar os custos e benefícios dos diferentes arranjos possíveis para não chegar a conclusões precipitadas sem o amparo de uma avaliação mais aprofundada.

Para poderem trafegar, os operadores ferroviários deverão:

\footnotetext{
${ }^{221}$ A aquisição de capacidade ociosa das concessionárias verticalmente integradas será realizada por meio de contrato de cessão onerosa do direito de uso da capacidade ociosa.

222 Observa-se que na Austrália, onde o "open access” foi implementado durante processo de reforma do setor ferroviário iniciado em 1996, a empresa estatal ARTC tem entre suas atribuições a venda de acesso a malhas exploradas pela própria estatal, bem como a malha operada por uma outra empresa, em caso de tráfego que ultrapasse os limites do Estado onde a ferrovia está localizada.

${ }^{223}$ É importante destacar que a maior parte das novas ferrovias que serão concedidas no marco do novo modelo de exploração não se conecta diretamente a portos ou mercados consumidores. Como consequência, é provável que os fluxos por essas novas vias férreas demandem a utilização de ferrovias concedidas a duas ou mais concessionárias distintas.
} 
- $\quad$ adquirir junto à Valec o direito de acesso às ferrovias, por meio de contratos “take or pay” de cessão onerosa do direito de uso de capacidade de tráfego que estabelecerá a tarifa de capacidade de tráfego (TCT); e celebrar 'Contrato Operacional de Transporte' com a concessionária titular da outorga para exploração da infraestrutura ferroviária - que estabelecerá as regras de acesso e utilização da infraestrutura ferroviária, bem como a tarifa de fruição $(\mathrm{TF})$ pela utilização da via.

Em função da coexistência de dois modelos de exploração ferroviária distintos, a tarifa de fruição será definida em bases diferenciadas. Para acesso a vias geridas por ‘concessionárias horizontais', a TF será estabelecida a partir dos valores resultantes do leilão de concessão e posteriores reajustes e revisões. ${ }^{224}$ Já para acesso às malhas operadas por concessionárias verticalmente integradas, a tarifa de fruição será negociada livremente entre as partes. Em ambos os casos, os operadores irão negociar diretamente com os usuários os fretes a serem cobrados na prestação do serviço de transporte, respeitando-se as tarifas de referência quando envolver o transporte por vias outorgadas a 'concessionárias verticais'.

Cabe mencionar que um dos aspectos sensíveis e que merecem atenção para permitir a integração efetiva e segura do sistema ferroviário diz respeito à interoperabilidade, exigindo, por exemplo, padrões de sinalização e comunicação compatíveis; tema que ainda prescinde de regulamentação. Neste contexto, ainda poderá ser objeto de discussão a necessidade de uma agência autônoma que zele pela segurança do tráfego ferroviário, nos moldes das instituições existentes em países como Reino Unido e Austrália.

\subsection{MODELAGEM DAS NOVAS CONCESSÕES FERROVIÁRIAS}

\footnotetext{
${ }^{224}$ Cf. minuta de contrato, "a concessionária poderá praticar descontos nas tarifas de fruição, baseados em parâmetros objetivos e isonômicos previamente divulgados, tais como a qualidade dos serviços, horário, dia ou temporada", o que caracteriza discriminação de preços de terceiro grau.
} 
Os estudos financeiros que embasarão os processos licitatórios das novas concessões ferroviárias incluem o cálculo do valor presente líquido do fluxo de caixa projetado, a partir do qual é estabelecido o valor máximo da combinação de tarifas a ser aceito para efeito de apresentação da proposta econômica. Para tanto, foi atribuída pelo governo uma taxa interna de retorno (TIR) real e de projeto de $8,5 \%$ ao ano e prazo de concessão pelo período de 35 anos. As minutas de contrato de concessão preveem a possibilidade de prorrogação por uma única vez, por no máximo igual período, apenas para recomposição do equilíbrio econômicofinanceiro. Com relação à TIR de projeto, a sua utilização se limitará ao cálculo da tarifa teto do leilão e não constará do contrato de concessão. No decorrer do período contratual, poderão ser calculadas novas taxas de desconto durante os processos de revisão tarifária, na medida em que houver necessidade de utilização de fluxo de caixa marginal. Para tanto, a minuta de contrato prevê a utilização da metodologia WACC (Weighted Average Cost of Capital) para determinação da referida taxa de desconto.

Os vencedores dos leilões serão definidos com base no menor Valor da Proposta Econômica (VPE), que resultará da combinação dos valores da Tarifa Básica de Disponibilidade da Capacidade Operacional (TBDCO) e da Tarifa Básica de Fruição (TBF). Cabe observar, deste modo, que o principal fator que diferenciará as propostas econômicas será o preço de construção/manutenção/operação ofertado por cada licitante.

A remuneração da concessionária será composta por um componente atrelado à disponibilização da capacidade operacional (que deverá remunerar os investimentos e os custos fixos incorridos na manutenção da via) - denominada Tarifa de Disponibilidade da Capacidade Operacional (TDCO) ${ }^{225}$, e outro associado à utilização dessa capacidade (que deverá remunerar os custos variáveis gerados pela utilização da ferrovia) - denominada

\footnotetext{
${ }^{225}$ A TDCO será a TBDCO incorporando-se os reajustes e revisões.
} 
Tarifa de Fruição $(\mathrm{TF})^{226}$, conforme ilustrado na Figura 11. A TDCO será paga pela Valec 227 à concessionária, que, conforme mencionado, receberá o pagamento da TF diretamente do operador ferroviário. Por outro lado, os operadores pagarão à Valec, pelo direito de acesso à via, a Tarifa de Capacidade de Tráfego (TCT).

Figura 11 - Ilustração referente às tarifas envolvidas no tráfego pelas malhas concedidas às "concessionárias horizontais" no marco do novo modelo de exploração ferroviária

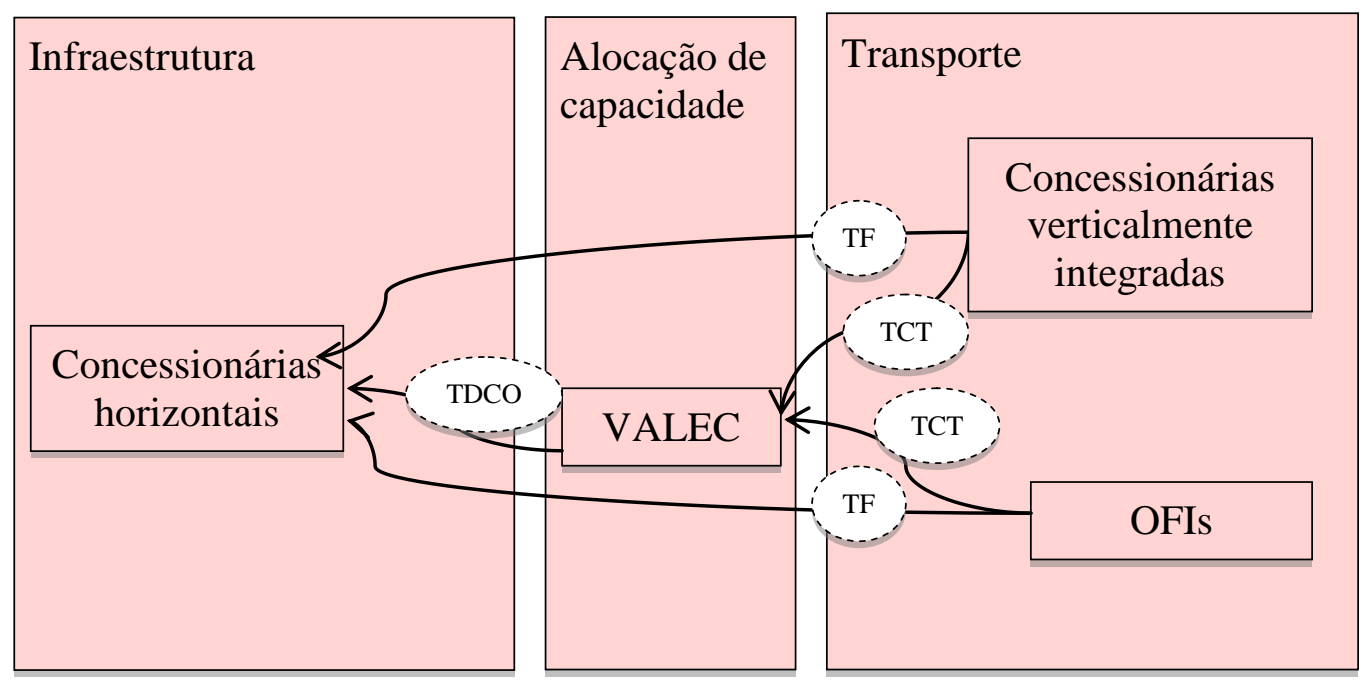

As minutas de contrato preveem reajustes e revisões tarifárias de três tipos, voltados à preservação do equilíbrio econômico-financeiro:

- reajustes anuais da TBDCO e TBF pela variação do IPCA;

- revisões ordinárias da TBDCO a cada cinco anos; e

- revisões extraordinárias da TBDCO e da TBF, observando-se a matriz de alocação de riscos constante no contrato.

\footnotetext{
${ }^{226}$ A TF será a TBF incorporando-se os reajustes e revisões.

${ }^{227}$ Com relação à Valec como responsável pela compra da integralidade da capacidade operacional da ferrovia, é fundamental o papel das garantias, dada a possibilidade de comportamento oportunista por parte do governo, e tendo em vista a especificidade do ativo.
} 
Deste modo, um aspecto chave para o êxito do modelo envolve uma alocação de riscos adequada, que considere a parte que está em melhores condições de assumir cada risco. Conforme RIBEIRO $(2011)^{228}$, as principais funções do sistema de equilíbrio econômicofinanceiro são: “a) desestimular a realização de alterações oportunistas pelo governante, exigindo que qualquer alteração seja devidamente compensada; b) proteger, estabilizar e dar cumprimento ao cerne do contrato, permitindo que seja dado cumprimento adequado à matriz de riscos ao longo do tempo; c) possibilitar a realização de alterações no objeto, quantitativa e qualitativas, e em outros aspectos do contrato para adequá-lo às necessidade e mudanças consequentes da passagem de tempo".

$\mathrm{Na}$ minuta de contrato das novas concessões ferroviárias, a matriz de alocação de riscos encontra-se explícita. Vale ressaltar que os riscos do concedente se limitam aos explicitados no contrato enquanto os riscos assumidos pelas concessionárias podem envolver outros que venham a surgir durante o período de concessão. Conforme se observa, há um elevado nível de detalhamento e complexidade, sugerindo que o regulador tentou antecipar muitas das possíveis contingências futuras. Neste contexto, cabem comentários sobre a alocação de alguns dos riscos referidos nas minutas:

- Riscos socioambientais e de desapropriação. No caso do licenciamento ambiental, a Empresa de Planejamento e Logística (EPL), estatal vinculada ao Ministério dos Transportes, será responsável pela condução dos estudos ambientais e atuará como empreendedor para efeito de emissão da Licença Prévia (LP). Como o licenciamento socioambiental envolve a atuação de órgãos burocráticos, entende-se que com a assunção deste risco pelo concedente, criam-se incentivos ao governo para a agilização dos trâmites necessários. Cabe mencionar que para (RIBEIRO, 2011) ${ }^{229}$, o

\footnotetext{
${ }^{228}$ RIBEIRO (2011, p.105-107)

${ }^{229}$ RIBEIRO (2011, p. 86)
} 
risco associado à obtenção de licenças ambientais deveria ser, preferencialmente, do parceiro privado, exceto em casos de obras complexas, como a construção de grandes usinas hidrelétricas. Adicionalmente, tanto os custos socioambientais, como os custos e indenizações com desapropriações, estarão limitados a valores previamente estipulados nos contratos. Caso superem esses limites, o concessionário fará jus à recomposição do equilíbrio econômico-financeiro de totalidade do valor excedente, caso o traçado definitivo esteja compreendido na faixa de licenciamento ambiental, ou de $50 \%$ do valor excedente, caso contrário. RIBEIRO (2011) ${ }^{230}$ observa que a alocação preferencial para o risco de preços excedentes para desapropriação seria do poder concedente. $\mathrm{O}$ mesmo autor entende que no caso de riscos relativos a custos socioambientais, a alocação preferencial seria definida por mecanismo de compartilhamento. Deste modo, conclui-se que a alocação prevista na minuta de contrato de concessão está de acordo com a recomendação teórica. Da mesma forma, entende-se que a limitação dos riscos socioambientais e de desapropriação contribui para a atração de investidores estrangeiros que, não conhecendo as especificidades brasileiras, teriam dificuldades para dimensionar os custos associados em caso de alocação privada do risco.

- Risco de descumprimento pelo concedente de suas obrigações contratuais ou regulamentares; Risco de modificações na legislação e regulamentação; Risco configurador de fato do príncipe ${ }^{231}$; Risco de mudança no projeto ou cronograma por iniciativa do concedente. A assunção destes riscos pelo concedente garantem conforto

\footnotetext{
${ }^{230}$ RIBEIRO (2011, p.85-86)

${ }^{231}$ Cf. MEIRELLES (2011, p.221) 'fato do príncipe' é toda determinação estatal, positiva ou negativa, geral, imprevista e imprevisível, que onera substancialmente a execução do contrato administrativo.
} 
ao concessionário contra possíveis comportamentos oportunistas por parte do regulador.

- Riscos de projeto, construção e operação: conforme se observa, a maior parte dos riscos associados a estas categorias foram alocadas ao concessionário, podendo ser caracterizado como mecanismos de incentivo ao cumprimento de prazos, minimização dos custos e garantia da qualidade.

Por se referir a uma das características centrais do modelo, o risco de demanda merecerá uma análise mais detalhada. A minuta de contrato prevê um mecanismo para que o investidor possa ter garantido o ressarcimento pelo investimento, independente da realização da demanda projetada. ESTACHE, JUAN e TRUJILLO (2011) ${ }^{232}$ sugerem como alternativa à garantia de receita, para efeito de proteção ao risco de demanda, a utilização de contratos com prazo variável. Neste caso, o contrato se encerra quando a demanda acumulada alcança o nível estipulado no edital. Este mesmo procedimento pode ser realizado ex post, por meio de extensão do prazo contratual. Os autores ponderam, contudo, que apesar de esse formato envolver risco limitado ao setor público, ele pouco colabora no apoio ou melhoria do financiamento privado.

Por meio de estudo em que analisa 27 projetos internacionais de parceria públicoprivada no setor ferroviário, DEHORNOY $(2012){ }^{233}$ observa que as concessões baseadas na disponibilidade ("availability-based concessions") têm ampliado sua participação com relação às concessões baseadas no tráfego ("traffic-based concessions"). Nas concessões do primeiro tipo, a autoridade pública retém o risco comercial, realizando pagamentos ao concessionário com base em indicadores de desempenho, enquanto no segundo caso, o concessionário recebe a receita comercial, sem ser remunerado pela autoridade pública

\footnotetext{
${ }^{232}$ ESTACHE, JUAN e TRUJILLO (2011, p. 720)

${ }^{233}$ DEHORNOY (2012, p.3)
} 
durante a operação. Exemplos de projetos com risco comercial alocado ao setor público são os de Diabolo e Liefkenshoek (Bélgica), Denver Eagle (Estados Unidos).

Neste ponto, cabe um comentário sobre o papel da Valec como responsável pela aquisição da totalidade da capacidade operacional das ferrovias, ainda que a estatal não consiga subceder a capacidade adquirida. O governo, por meio da Valec, arcará com o ônus de remunerar a concessionária pelo capital investido e pelos custos fixos incorridos, independentemente das condições reais de demanda, assumindo, deste modo, a maior parte do risco comercial (ou risco de tráfego). Conforme DEHORNOY (2012) ${ }^{234}$, o risco de tráfego em projetos no setor ferroviário é elevado e de difícil mitigação, dado que, diferentemente de projetos de rodovias e aeroportos, os projetos ferroviários sempre apresentaram baixa taxa de autofinanciamento, e agrega que não há motivos para acreditar que regimes de contratação envolvendo parcerias público-privadas modifiquem essa condição. Deste modo, o autor observa que a maior parte dos projetos de concessão ferroviária em que o risco de demanda é alocado ao parceiro privado resultou em fracassos financeiros. IOSSA e MARTIMORT $(2011)^{235}$ sugerem como solução para projetos com elevada incerteza de demanda e alta aversão ao risco a utilização de mecanismo de pagamento associado à remuneração pela disponibilidade da capacidade, vis-à-vis à remuneração pelo uso da capacidade. Conforme destacado, os custos fixos em um projeto ferroviário representam pelo menos $70 \%$ do custo total, além de envolverem ativos específicos. Agregando-se o fato de serem em sua maioria projetos "greenfield" ${ }^{, 236}$, entende-se que haveria grande dificuldade em se atrair potenciais investidores para os projetos ferroviários em referência, ou o prêmio pela assunção do risco

\footnotetext{
${ }^{234}$ DEHORNOY $(2012$, p.5)

${ }^{235}$ IOSSA e MARTIMORT (2011, p.693)

${ }^{236}$ A maior parte das novas concessões ferroviárias envolverão o modelo DBFOT ("Design, Build, Finance, Operate, Transfer”) em que o setor privado terá como responsabilidade o financiamento, elaboração do projeto, construção, operação e transferência da ferrovia passados 35 anos do prazo de concessão.
} 
seria muito elevado caso o governo não minimizasse o risco de demanda do concessionário. Segundo RIBEIRO $(2011)^{237}$, apesar de o risco de demanda ter alocação preferencialmente para o parceiro privado, em casos em que o referido risco é muito elevado e não havendo como controlá-lo, "faz sentido atribuí-lo parcial ou totalmente ao poder concedente".

Por outro lado, é fundamental a adoção de medidas para assegurar o pagamento pela disponibilidade da infraestrutura (função atribuída pelo governo à Valec), que remunerará os custos fixos da concessionária. Como observado, em projetos que envolvem contratos de longo prazo, grande volume de investimento e especificidade do ativo, os governos são tentados a agir de forma oportunista. Ao longo de 35 anos de contrato serão mais de oito governos, ou seja, o comprometimento de um, não necessariamente garantirá o dos demais. Portanto, a adoção de todas as medidas de garantia necessárias previamente à assinatura dos contratos é fundamental.

As minutas de contrato incluem a previsão de utilização de três mecanismos de regulação tarifária:

- Acréscimo de Reequilíbrio: percentual que será incrementado à TBDCO, mediante a aplicação do Fator “d”, em caso de atraso no início da operação da ferrovia decorrente de fatos não imputáveis à concessionária. Conforme a alínea (viii) da subcláusula 25.2 da minuta de contrato, a concessionária não é responsável por atraso no início da Operação da Ferrovia pelos motivos expostos na subcláusula 10.1.5, que fossem impossíveis de prever quando da assinatura do contrato e decorrente de fatos não imputáveis à concessionária, retardando a arrecadação da sua remuneração: (a) Presume-se como fato imputável à Concessionária qualquer atraso decorrente da não entrega de todos os documentos, estudos e informações exigidos pelos órgãos competentes, ou em qualidade inferior ao mínimo estabelecido prévia ou posteriormente ao pedido inicial. Neste sentido, em caso de atraso, a concessionária terá

\footnotetext{
${ }^{237}$ RIBEIRO (2011, p.92)
} 
direito ao acréscimo denominado "acréscimo de reequilíbrio". Entende-se que este mecanismo servirá de incentivo para que o concedente cumpra os prazos que sejam de sua responsabilidade.

- Fator de ajuste da disponibilidade de capacidade (Fator “i”): percentual a ser multiplicado à TDCO; refletirá a capacidade operacional da ferrovia efetivamente disponibilizada, e será apurado a cada trimestre para efeito de remuneração da concessionária. Observa-se que este mecanismo cria incentivos para que o regulado garanta a qualidade da infraestrutura, com a disponibilização da capacidade contratada. Por outro lado, a minuta de contrato não deixa claro se este fator poderá exceder a $100 \%$, o que favoreceria à melhoria da eficiência por parte da concessionária, ao ampliar a oferta de capacidade operacional da ferrovia.

- Fator de evolução da produtividade (Fator “x”): percentual a ser multiplicado à TBF a partir do $11^{\circ}$ ano de concessão; representará ajuste baseado na expectativa de evolução da produtividade da concessionária. Entre o $11^{\circ}$ e o $15^{\circ}$ ano da data de assunção, o fator " $\mathrm{x}$ " será fixo e igual a 1,9\%; para os quinquênios subsequentes, o percentual será definido por meio de metodologia a ser regulamentada pela $\mathrm{ANTT}^{238}$. Este fator, inspirado no mecanismo price cap, também pode ser visto como um incentivo à melhoria de produtividade por parte da concessionária.

A minuta de contrato prevê ainda que durante o período de obras, a Valec antecipará à concessionária o valor equivalente a $15 \%$ do total dos investimentos (Capex), que será abatido linearmente da receita a ser percebida durante o período de operação da ferrovia,

\footnotetext{
${ }^{238}$ Cf. minuta de contrato de concessão, o fator "x" será igual a 0 até o $10^{\circ}$ ano da data de assunção, e igual a $1,9 \%$, no período compreendido entre o $11^{\circ}$ e o $15^{\circ}$ ano. A partir do $16^{\circ}$ ano, o fator será fixado quinquenalmente por metodologia a ser estabelecida pela ANTT até 6 meses antes do advento do $16^{\circ}$ período, que deverá levar em consideração os seguintes princípios: (i) promoção da eficiência operacional; (ii) isonomia no tratamento das concessionárias, mas considerando as peculiaridades de cada trecho ferroviário; e (iii) transparência e simplicidade. Observa-se que não está previsto o prazo para a fixação do fator "x" a ser utilizado a partir do $16^{\circ}$ ano.
} 
desde que as obras estejam de acordo com o cronograma de execução física. Observa-se que este dispositivo se caracteriza como incentivo para que a regulada cumpra o cronograma estabelecido.

Em estudo teórico desenvolvido por IOSSA e MARTIMORT (2011), em que os autores identificam situações nas quais as principais características das parcerias públicoprivadas contribuem para a geração de incentivos a fornecedores privados em projetos do setor de transportes, os autores notam que a opção de contratação agregada (elaboração de projeto, construção, financiamento e operação) - "bundling" - é estritamente superior à contratação desagregada, uma vez que o "bundling" promove mais esforços para a melhoria da qualidade da construção e redução de custos. Como quem constrói também vai operar, já se internaliza na fase de construção incentivos para se ter infraestruturas que não implicarão custos elevados de manutenção e operação. Quando a contratação é feita de forma individualizada, é plausível que o construtor tenha incentivos para economizar na qualidade do material e dos serviços, o que resultará em maiores gastos futuros com manutenção e operação. Como consequência, entende-se que a opção pela concessão destas atividades ao setor privado de forma agregada se confirma como a alternativa mais eficiente.

No entanto, um ponto sensível associado às próximas concessões ferroviárias diz respeito à possibilidade de se selecionar licitantes que apresentem menores propostas econômicas, com prévia intenção de que as tarifas sejam renegociadas, como resultado de um comportamento oportunista. Esta situação ocorre, conforme GUASCH (2004 apud MATTOS, 2012), se os licitantes acreditarem que a renegociação é viável e provável, afetando seus incentivos e propostas, e, desta forma, o leilão selecionará, não o provedor mais eficiente, mas aquele com melhores habilidades de negociação ${ }^{239}$. MATTOS (2012) destaca que o comportamento oportunista dos concessionários é mais comum em situações ${ }^{239}$ GUASCH (2004 apud MATTOS, 2012) 
em que os investimentos são essenciais, sendo este o caso da maior parte das próximas concessões ferroviárias, que envolvem a construção da infraestrutura ferroviária, implicando em elevados "sunk costs". Em condições como esta, o regulador tende a estar mais propenso a aceitar a renegociação - tendo o concessionário maior poder de barganha, dados os custos a serem incorridos e os atrasos resultantes, caso se defina, por exemplo, pela realização de uma nova licitação. Entende-se que uma alocação de riscos eficiente tende a minimizar este aspecto, mas, dificilmente irá extingui-lo. Da mesma forma, evidências encontradas por GUASCH (2004 apud MATTOS, 2014) sugerem que leilões cujo critério é a menor tarifa tendem a ser mais propensos à renegociação do que aqueles que se baseiam no maior valor de outorga, sendo o primeiro formato o escolhido para as novas concessões ferroviárias.

De modo geral, cabem ser destacados três aspectos que merecem atenção. O primeiro se refere à previsão contratual de acréscimo de reequilíbrio tarifário, por meio do fator "d", associado a atrasos nas obras por razões não imputáveis à concessionária. Estará nas mãos do regulador a análise das justificativas apresentadas pela regulada, sendo que em função da assimetria de informação existente entre o concedente e a concessionária, não necessariamente haverá amparo da matriz de alocação de riscos. Em segundo lugar, conforme mencionado, a maior parte das novas concessões envolverá malhas cuja localização implicará a utilização adicional de uma ou mais malhas administradas por concessionárias verticalmente integradas. Nesse sentido, o tráfego por essas malhas dependerá da existência de capacidade ociosa nos trechos requeridos. Portanto o sucesso do modelo dependerá da disponibilidade e disponibilização dessa capacidade ociosa a operadores ferroviários independentes.

O último aspecto guarda relação com o histórico recente de atrasos nos cronogramas de execução de obras sob responsabilidade de concessionárias do setor de transportes, ensejando renegociações. Como exemplo tem-se a construção da Ferrovia Nova 
Transnordestina, que apresenta, até o momento, atraso de 69 meses (com relação ao cronograma original) e elevação de $39 \%$ (de $\mathrm{R} \$ 5,4$ bilhões para $\mathrm{R} \$ 7,5$ bilhões) nos custos de implantação. Ou seja, será o concedente capaz de garantir o cumprimento do contrato?

Por fim, entende-se que a atuação da agência reguladora e da Valec serão decisivas no desenvolvimento exitoso do setor ferroviário brasileiro. Sendo adequada, ter-se-á como resultados a atração de investimentos privados, a eficiência setorial e o aumento do bem-estar dos usuários. Em última instância, os impactos serão sentidos nos diversos setores da economia brasileira. 


\section{CONSIDERAÇÕES FINAIS}

O novo modelo de exploração ferroviária a ser adotado para as novas concessões brasileiras acompanha movimento que se encontra mais presente, sobretudo, na União Europeia e Austrália. Com base na análise realizada, verifica-se que diversos países optaram pela separação vertical como um primeiro passo no processo de reforma do setor, tendo-se observado ainda que, na maior parte dos casos, a gestão da infraestrutura não foi transferida para o controle privado, ou foi, mas retornou ao controle estatal ${ }^{240}$. Por outro lado, no continente americano, especialmente em países como Estados Unidos e Canadá, não se nota tendência à implementação de separação vertical, possivelmente pelo fato de nesses países existir concorrência intramodal nos principais corredores.

Da mesma forma, observa-se que o regime de "open access" encontra-se mais difundido na União Europeia e Austrália, ainda que também tenha sido adotado em países que não promoveram a separação vertical. Verificou-se, deste modo, que as combinações de modelos de exploração ferroviária são bastante variadas e, conforme DI PIETRANTONIO e PELKMANS (2004) ${ }^{241}$, nenhum modelo per si é o melhor. De fato, a escolha depende de características intrínsecas de tráfego, escala, densidade e demandas de mercado de cada realidade e, não necessariamente a melhor opção envolve a escolha de um único modelo. No caso brasileiro, as principais motivações que ensejaram a opção pela implementação conjugada do "unbundling” e “open access” estão relacionadas às limitações observadas no modelo de concessão vigente, que resultaram no atendimento a uma quantidade de usuários/setores aquém do potencial, que, por sua vez, pode ser consequência dos reduzidos

\footnotetext{
${ }^{240}$ Exemplos: Reino Unido e Nova Zelândia.

${ }^{241}$ DI PIETRANTONIO e PELKMANS (2004, p.24)
} 
incentivos ao investimento na expansão da malha e tarifas não competitivas. ${ }^{242}$ Contudo, caberia uma análise específica que tratasse de identificar se para a circunstância brasileira, a combinação de separação vertical e "open access" seria a mais recomendável. Cumpre destacar que, na proposta brasileira, outro desafio estará associado à convivência de dois modelos de exploração ferroviária - vertical e com separação vertical, o que ampliará a complexidade do ambiente regulatório no setor. A experiência australiana se mostra como uma referência importante, neste aspecto, tendo em vista a convivência de ambos os modelos, regulados por uma multiplicidade de normas e instituições nas diferentes jurisdições estaduais/federal.

A diferença mais notável e comentada do novo modelo brasileiro de exploração ferroviária diz respeito à participação da estatal Valec como agente responsável pela gestão da capacidade de transporte das novas ferrovias. Com relação a seu papel na venda de capacidade a operadores ferroviários, nota-se que países como Suíça e Hungria implementaram solução semelhante, com separação completa das atividades essenciais, como forma de mitigar a possibilidade de tratamento discriminatório. Alternativamente, países como Itália e Alemanha optaram pelo estabelecimento de mecanismos regulatórios e de "compliance" aprimorados, sem introduzir um novo agente ao modelo, o que favorece à redução dos custos transacionais. Adicionalmente, cabe mencionar o caso da Austrália, onde o gestor de infraestrutura ferroviária federal (ARTC) vende capacidade das malhas por ele controladas, além de capacidade de ferrovias geridas por terceiros, com vistas a atuar como “one-stop-shop", podendo ser considerado este um benefício associado à atuação da Valec. Neste contexto, sugere-se que sejam estudadas as diversas opções possíveis que poderiam contribuir para assegurar o tratamento não discriminatório a operadores entrantes, tendo em

\footnotetext{
${ }^{242}$ Segundo NASH (2011, p. 776), há boas evidências de que a competição nos trilhos traz benefícios para o transporte de graneis e containers, mas não está claro se os mesmos benefícios podem ser alcançados com uma forte regulação, sem efetivar a separação completa.
} 
vista o modelo de separação vertical organizacional adotado no país. Da mesma forma, tendo a Valec como responsável pela alocação de capacidade, caberia analisar se a melhor opção seria manter a restrição às novas concessionárias com relação à exploração da atividade de prestação do serviço de transporte, tendo em vista a garantia de não discriminação proporcionada pela intermediação da estatal na relação concessionária/OFI.

No que tange ao papel da Valec na compra da totalidade da capacidade das novas ferrovias a serem construídas em regime de concessão, observou-se que há evidências de que concessões baseadas na disponibilidade ("availability-based concessions") seriam mais adequadas para projetos ferroviários. Assim mesmo, valeria pesquisar, por exemplo, em projetos ferroviários "greenfield" conduzidos por outros países, alternativas de modelagens que reduzam a participação estatal e que poderiam ser replicadas no Brasil.

Considerando-se os problemas de coordenação apontados como uma das fragilidades centrais do modelo de exploração ferroviária envolvendo a separação vertical e "open access", um ponto crucial está relacionado ao alinhamento de incentivos. Tendo em vista a presença de diversos atores com objetivos próprios e, muitas vezes, conflitantes e/ou contrários, é fundamental que o modelo incorpore mecanismos que propiciem a cooperação. Estudos mais aprofundados sobre o tema são recomendados.

Por último, cabe destacar que um ponto sensível de qualquer modelo que envolva parcerias entre o governo e o setor privado está associado à capacidade institucional do Estado brasileiro em prover as condições necessárias para a boa execução (para todas as partes) dos contratos. Neste sentido, as instituições estatais diretamente envolvidas, sobretudo, a ANTT e a Valec, terão a importante missão de garantir o cumprimento das condições acordadas tanto pelo governo como pelas concessionárias, sendo um dos requisitos para o estabelecimento de um ciclo virtuoso de investimento em infraestrutura no país. Resgatando o primeiro capítulo deste trabalho, o investimento em infraestrutura, e, 
particularmente, em ferrovias, é imprescindível para a redução do "custo Brasil". Portanto, entende-se que, ao menos nesse aspecto, as opiniões são convergentes. 


\section{REFERÊNCIAS}

ABRAMILHO (2014). Exportação de milho despenca e pesa mais que Argentina na balança. Website da ABRAMILHO, 15 março 2014. Disponível em:

<http://www.abramilho.org.br/noticias.php?cod=3058>.

ANTF (2014). Ferronorte S.A. - Ferrovias Norte Brasil. ANTF. Disponível em: <http://www.antf.org.br/pdfs/Ferronorte.pdf >.

ANTT (2003a). Relatório Anual de Acompanhamento das Concessões Ferroviárias 2002. ANTT. Brasília. Disponível em:

<http://appweb2.antt.gov.br/relatorios/ferroviario/concessionarias2002/index.asp>.

ANTT (2003b). Resolução ANTT nº 288, 10 de setembro de 2003. Disponível em: <http://www.antt.gov.br/index.php/content/view/1288/Resolucao_n_288.html>.

ANTT (2004). Relatório Anual de Acompanhamento das Concessões Ferroviárias 2003. ANTT. Brasília. Disponível em:

<http://appweb2.antt.gov.br/relatorios/ferroviario/concessionarias2003/index.asp>.

ANTT (2005). Relatório Anual de Acompanhamento das Concessões Ferroviárias 2004. ANTT. Brasília. Disponível em:

<http://appweb2.antt.gov.br/relatorios/ferroviario/concessionarias2004/index.asp>.

ANTT (2007a). Relatório Anual de Acompanhamento das Concessões Ferroviárias 2005. ANTT. Brasília. Disponível em:

<http://appweb2.antt.gov.br/relatorios/ferroviario/concessionarias2005/index.asp>.

ANTT (2007b). Relatório Anual de Acompanhamento das Concessões Ferroviárias 2006. ANTT. Brasília. Disponível em:

<http://appweb2.antt.gov.br/relatorios/ferroviario/concessionarias2006/index.asp>.

ANTT (2008). Relatório Anual de Acompanhamento das Concessões Ferroviárias 2007. ANTT. Brasília. Disponível em:

<http://appweb2.antt.gov.br/relatorios/ferroviario/concessionarias2007/index.asp>.

ANTT (2009a). Anuário Estatístico dos Transportes Terrestres - AETT 2009. ANTT. Brasília. Disponível em:

<http://appweb2.antt.gov.br/InformacoesTecnicas/aett/aett_2009/principal.asp>.

ANTT (2009b). Relatório Anual de Acompanhamento das Concessões Ferroviárias 2008. ANTT. Brasília. Disponível em:

<http://appweb2.antt.gov.br/relatorios/ferroviario/concessionarias2008/index.asp>.

ANTT (2010). Relatório Anual de Acompanhamento das Concessões Ferroviárias 2009. ANTT. Brasília. Disponível em:

<http://www.antt.gov.br/index.php/content/view/4994/Relatorios_Anuais.html\#lista>.

ANTT (2011a). Relatório Anual de Acompanhamento das Concessões Ferroviárias 2010. ANTT. Brasília. Disponível em:

<http://www.antt.gov.br/index.php/content/view/4994/Relatorios_Anuais.html\#lista>. 
ANTT (2011b). Resolução ANTT no 3.694, 14 de julho de 2011. Disponível em: <http://www.antt.gov.br/index.php/content/view/4694/Resolucao_n_3694.html>.

ANTT (2011c). Resolução ANTT nº 3.695, 14 de julho de 2011. Disponível em: <http://www.antt.gov.br/index.php/content/view/4695/Resolucao_n_3695.html>.

ANTT (2011d). Resolução ANTT no 3.696, 14 de julho de 2011. Disponível em: <http://www.antt.gov.br/index.php/content/view/4696/Resolucao_n_3696.html>.

ANTT (2012). Manual de Procedimentos de Fiscalização do RNTRC. ANTT. Disponível em: <http://www.antt.gov.br/html/objects/_downloadblob.php?cod_blob=10279>.

ANTT (2014a). Relatório Anual de Acompanhamento das Concessões Ferroviárias 2011. ANTT. Brasília. Disponível em:

<http://www.antt.gov.br/html/objects/_downloadblob.php?cod_blob=11145>.

ANTT (2014b). Relatório Anual de Acompanhamento das Concessões Ferroviárias 2012. ANTT. Brasília. Disponível em:

<http://www.antt.gov.br/html/objects/_downloadblob.php?cod_blob=12820>.

ANTT (2014c). Relatório Anual de Acompanhamento das Concessões Ferroviárias 2013. ANTT. Brasília. Disponível em:

<http://www.antt.gov.br/html/objects/_downloadblob.php?cod_blob=13449>.

ANTT (2014d). Resolução ANTT no 4.348, 05 de junho de 2014. Disponível em:

<http://www.antt.gov.br/index.php/content/view/33794/Resolucao_n_4348.html>.

ANTT (2014e). Website da ANTT. Disponível em: <http://www.antt.gov.br>.

AUSTRALASIAN RAILWAY ASSOCIATION - ARA (2013). Australasian Railway Association. Australian Rail Industry Report 2012. Disponível em:

$<$ http://www.ara.net.au/UserFiles/file/Publications/13-09\%20ARA-2011-12-Rail-IndustryReport.pdf $>$.

BAER, W. (1988). A industrialização e o desenvolvimento econômico do Brasil. Rio de Janeiro: Editora da Fundação Getúlio Vargas.

BAER, W.; KERSTENETZKY, I.; SIMONSEN, M. H. (1962). Transporte e Inflação: Um Estudo da Formulação Irracional de Política no Brasil. Revista Brasileira de Economia, Rio de Janeiro, v. 16, n. 4, p. 159-174, outubro 1962. Disponível em:

<http://bibliotecadigital.fgv.br/ojs/index.php/rbe/article/view/1823/2824>.

BCB. Série: 1208 - Produto interno bruto em R\$ do último ano (2013). BCB-Depec.

BNDES (2000). As Concessões Ferroviárias. Disponível em:

$<$ http://www.bndes.gov.br/SiteBNDES/export/sites/default/bndes_pt/Galerias/Arquivos/conh ecimento/seminario/ferro.pdf $>$.

BRACELPA (2014). Estatísticas: Balança Comercial do Setor - Fevereiro/2014.

BRACELPA, 12 março 2014. Disponível em:

$<$ http://bracelpa.org.br/bra2/sites/default/files/estatisticas/RM39BalancaComercial58-

Fevereiro2014.pdf $>$. 
BRASIL (1835a). Decreto Legislativo $\mathrm{n}^{\circ} 101,31$ de outubro de 1835. Disponível em: <http://www2.camara.leg.br/legin/fed/decret/1824-1899/decreto-101-31-outubro-1835562803-publicacaooriginal-86906-pl.html>.

BRASIL (1835b). Decreto Legislativo no 24, 17 de setembro de 1835. Disponível em: <http://www2.camara.leg.br/legin/fed/decret/1824-1899/decreto-24-17-setembro-1835562387-publicacaooriginal-86394-pl.html>.

BRASIL (1855a). Decreto n ${ }^{\circ} 1.599,09$ de maio de 1855. Disponível em: <http://www2.camara.leg.br/legin/fed/decret/1824-1899/decreto-1599-9-maio-1855-558531publicacaooriginal-79871-pe.html>.

BRASIL (1855b). Decreto $\mathrm{n}^{\circ}$ 1.664, 20 de outubro de 1855. Disponível em: $<$ http://www2.camara.leg.br/legin/fed/decret/1824-1899/decreto-1664-20-outubro-1855558675-publicacaooriginal-80175-pe.html .

BRASIL (1857). Decreto ${ }^{\circ}$ 1.930, 26 de abril de 1857. Disponível em: <http://www2.camara.leg.br/legin/fed/decret/1824-1899/decreto-1930-26-abril-1857-557950publicacaooriginal-78726-pe.html>.

BRASIL (1862). Decreto $\mathrm{n}^{\circ}$ 2.913, 23 de abril de 1862. Disponível em: <http://www2.camara.leg.br/legin/fed/decret/1824-1899/decreto-2913-23-abril-1862-555502publicacaooriginal-74751-pe.html>.

BRASIL (1873a). Decreto ${ }^{\circ} 2.237,03$ de maio de 1873. Disponível em: <http://www2.camara.leg.br/legin/fed/decret/1824-1899/decreto-2237-3-maio-1873-550569publicacaooriginal-66579-pl.html>.

BRASIL (1873b). Decreto ${ }^{\circ} 2.450,24$ de setembro de 1873. Disponível em: <http://www2.camara.leg.br/legin/fed/decret/1824-1899/decreto-2450-24-setembro-1873551003-publicacaooriginal-67086-pl.html>.

BRASIL (1874). Decreto $n^{\circ}$ 5.561, 28 de fevereiro de 1874. Disponível em: <http://www2.camara.leg.br/legin/fed/decret/1824-1899/decreto-5561-28-fevereiro-1874550146-publicacaooriginal-65785-pe.html>.

BRASIL (1878). Decreto ${ }^{\circ}$ 6.995, 10 de agosto de 1878. Disponível em: <http://www2.camara.leg.br/legin/fed/decret/1824-1899/decreto-6995-10-agosto-1878547889-publicacaooriginal-62781-pe.html>.

BRASIL (1880a). Decreto $\mathrm{n}^{\circ}$ 7.959, 29 de dezembro de 1880. Disponível em: <http://www2.camara.leg.br/legin/fed/decret/1824-1899/decreto-7959-29-dezembro-1880547352-publicacaooriginal-62081-pe.html>.

BRASIL (1880b). Decreto n ${ }^{\circ}$ 7.960, 29 de dezembro de 1880. Disponível em: <http://www2.camara.leg.br/legin/fed/decret/1824-1899/decreto-7960-29-dezembro-1880547353-publicacaooriginal-62082-pe.html .

BRASIL (1892). Decreto $n^{\circ}$ 1.164, 08 de dezembro de 1892. Disponível em: <http://www2.camara.leg.br/legin/fed/decret/1824-1899/decreto-1164-9-dezembro-1892541568-publicacaooriginal-46785-pe.html>. 
BRASIL (1934). Decreto $\mathrm{n}^{\circ} 24.497,29$ de junho de 1934. Disponível em: <http://www2.camara.leg.br/legin/fed/decret/1930-1939/decreto-24497-29-junho-1934526330-publicacaooriginal-1-pe.html >.

BRASIL (1987). Decreto n ${ }^{\circ} 94.813,01$ de setembro de 1987. Disponível em: <www2.camara.leg.br/legin/fed/decret/1980-1987/decreto-94813-1-setembro-1987-445715publicacaooriginal-1-pe.html>.

BRASIL (1992a). Decreto no 473, 10 de março de 1992. Disponível em: <http://www.planalto.gov.br/ccivil_03/decreto/1990-1994/D0473.htm>.

BRASIL (1992b). Decreto no 473, 10 de março de 1992. Disponível em: <http://www.planalto.gov.br/ccivil_03/decreto/1990-1994/D0473.htm>.

BRASIL (1994). Decreto no 1.204, 29 de julho de 1994. Disponível em: <http://www.planalto.gov.br/ccivil_03/decreto/D1204.htm>.

BRASIL (1995a). Lei no 8.987, 13 de fevereiro de 1995. Disponível em: <http://www.planalto.gov.br/ccivil_03/leis/18987cons.htm>.

BRASIL (1995b). Lei no 9.074, 07 de julho de 1995. Disponível em: <http://www.planalto.gov.br/ccivil_03/leis/19074cons.htm>.

BRASIL (2001). Lei no 10.233, 05 de junho de 2001. Disponível em: <http://www.planalto.gov.br/ccivil_03/leis/leis_2001/110233.htm>.

BRASIL (2013a). Decreto $n^{\circ} 8.129,23$ de outubro de 2013. Disponível em: < http://www.planalto.gov.br/CCIVIL_03/_Ato2011-2014/2013/Decreto/D8129.htm>.

BRASIL (2013b). Lei no 12.815, 05 de junho de 2013. Disponível em: <http://www.planalto.gov.br/ccivil_03/_ato2011-2014/2013/Lei/L12815.htm>.

CAMPOS, J.; CANTOS, P. (2000). Rail Transport Regulation. In: RUS, G.; ESTACHE, A. Privatization and regulation of transport infrastructures: guidelines for policymakers and regulators. Washington D.C.: The World Bank Institute. Disponível em: <http://elibrary.worldbank.org/doi/pdf/10.1596/1813-9450-2064>.

COASE, R. H. (1960). The Problem of Social Cost, v. 3, Outubro de 1960. Disponível em: <http://www2.econ.iastate.edu/classes/tsc220/hallam/Coase.pdf>.

CONAB (2014). Séries Históricas: Safras: Produtos e Serviços: CONAB. Website da CONAB. Disponível em:

$<$ http://www.conab.gov.br/conteudos.php?a=1252\&t=2\&Pagina_objcmsconteudos=3\#A_obj cmsconteudos>.

CORREA FILHO, V. (1954). Evolução Ferroviária do Brasil. In: IBGE I Centenário das Ferrovias Brasileiras. Rio de Janeiro: Serviço Gráfico do IBGE, 1954. p. 373-389.

Disponível em: <http://biblioteca.ibge.gov.br/visualizacao/monografias/GEBIS\%20\%20RJ/centenarioferrovias1954.pdf $>$.

DAHLMAN, C. J. (1979). The problem of externality. Journal of law and economics, v. 22, p. 141-162, abril 1979. 
DEHORNOY, J. (2012). PPPs in the rail sector - A review of 27 projects. Munich Personal RePEc Archive, 15 p.

DE MATOS, O. N. (1974). Café e ferrovias: a evolução ferroviária de São Paulo e o desenvolvimento da cultura cafeeira. São Paulo: Editora Alfa-Omega. 135 p.

DE SOUSA, R. A.; PRATES, H. F. (1997). O Processo de Desestatização da RFFSA: Principais Aspectos e Primeiros Resultados. Revista do BNDES, Rio de Janeiro, 4, n. 8, dezembro 1997. p. 119-142.

DI PIETRANTONIO, L.; PELKMANS, J. (2004). The Economics of EU Railway Reform. College of Europe. Bruges.

ESTACHE, A.; GOLDSTEIN, A.; PITTMAN, R. (2001). Privatization and Regulatory Reform in Brazil: The Case of Freight Railways. Disponível em: $<$ http://www.seae.fazenda.gov.br/central-de-documentos/documentos-detrabalho/documentos-de-trabalho-2001/DocTrab09.pdf $>$.

ESTACHE, A.; JUAN, E.; TRUJILLO, L. (2011). Public-Private partnerships in transport. In: DE PALMA, A., et al. A Handbook of Transport Economics. Northampton: Edward Elgar Publishing Limited, 2011. p. 708-725.

EUROPEAN COMISSION (2014). Fourth report on monitoring development in the rail market. Brussels. Disponível em:

<http://ec.europa.eu/transport/modes/rail/market/doc/swd\%282014\%29186_final__en.pdf>.

GÓMEZ-IBAÑEZ, J. A. (2003). Regulating infrastructure: monopoly, contracts, and discretion. Harvard University Press.

GUASCH, J. L. (2004). Granting and Renegotiating Infrastructure Concessions Doing it Right. The World Bank Institute.

IBGE (1990). Estatísticas Históricas do Brasil: Séries Econômicasl Demográficas e Sociais de 1550 a 1988. 2a. Edição revisada e atualizada. ed. Rio de Janeiro: IBGE.

IOSSA, E.; MARTIMORT, D. (2011). The theory of incentive applied to the transport sector. In: DE PALMA, A., et al. A Handbook of Transport Economics. Northampton: Edward Elgar Publishing Limited. p. 684-707.

JOSKOW, P. L. (2005). Regulation of Natural Monopolies. Center for Energy and Environmental Policy Research.

KIRCHNER, C. (2011). Rail Liberalization Index 2011. IBM Global Business Services. Brussels. Prior issues of this index were prepared in 2002, 2004 and 2007. Disponível em: <http://www.deutschebahn.com/file/2236524/data/study_rail_liberalisation_index_2011 _presentation.pdf $>$.

KLINCEVICIUS, M. G. Y. (2011). Estudo de propriedades, de tensões e do comportamento mecânico de lastros ferroviários. Universidade de São Paulo. São Paulo. Disponível em: <http://www.teses.usp.br/teses/disponiveis/3/3138/tde-27032012-121114/ptbr.php>. 
KUROSAKI, F. (2008). An Analysis of Vertical Separation of Railways. The University of Leeds. Leeds, 311 p. Disponível em:

<http://etheses.whiterose.ac.uk/682/3/fumiofinal081112.pdf?origin=publication_detail>.

LAFFONT, J.-J.; MARTIMORT, D. (2002). The Theory of Incentives: The PrincipalAgent Model. New Jersey: Princeton University Press. 440 p.

LAFFONT, J.-J.; TIROLE, J. (1993). A Theory of Incentives in Procurement and Regulation. MIT Press. 705 p.

LITTLECHILD, S. C. (1983). Regulation of British Telecommunications' profitability: report to the Secretary of State. Department of Industry.

LUCINDA, C. R. (2010). Regulação Tarifária: Princípios Introdutórios. In: SCHAPIRO, M. G. Direito econômico: direito econômico regulatório. São Paulo: Saraiva.

MATTOS, C. (2012). Concessões de Rodovias e Renegociação no Brasil.

MATTOS, C. (2014). Os Incentivos na Concessão de Aeroportos no Brasil: Equilíbrio Econômico e Financeiro do Contrato e Regulação Tarifária.

MEDAUAR, O. (2009). Direito Administrativo Moderno. Revista dos Tribunais, São Paulo, n. 13. p. 216-217.

MEIRELLES, H. L. (2011). Direito administrativo brasileiro. São Paulo: Malheiros Ed.

MERKERT, R; HENSHER, D.A. (2014). Open access for railways and transaction cost economics - Management perspectives of Autralia's rail companies. Sydney: Institute of Transport and Logistic Studies. Disponível em: <

http://sydney.edu.au/business/_data/assets/pdf_file/0004/204826/ITLS-WP-14-12.pdf>.

MINERAÇÃO RIO DO NORTE - MRN. (2014). Sobre a MRN: Perfil. Website da MRN.

Disponível em: <http://www.mrn.com.br/pt-BR/Sobre-MRN/Perfil/Paginas/default.aspx>.

MINISTÉRIO DO DESENVOLVIMENTO, INDÚSTRIA E COMÉRCIO EXTERIOR MDIC (2014). Ministério do Desenvolvimento, Indústria e Comércio Exterior. Sistema AliceWeb. Disponível em: 〈http://aliceweb.desenvolvimento.gov.br/>

MINISTÉRIO DOS TRANSPORTES - MT (2012). Projeto de Reavaliação de Estimativas e Metas do PNLT. setembro de 2012. Disponível em:

<http://www.transportes.gov.br/public/arquivo/arq1352743917.pdf>

NASH, C. (2011). Competition and regulation in rail transport. In: DE PALMA, A., et al. A Handbook of Transport Economics. Northampton: Edward Elgar Publishing Limited. p. 763-778.

NATIONAL MUSEUM WALES (2014). Explore Our Collections: Richard Trevithick's steam locomotive. National Museum Wales Website. Disponível em:

<http://www.museumwales.ac.uk/rhagor/article/trevithic_loco/>.

NORTH, D. C. (1990). A transaction cost theory of politics. Journal of Theoretical Politics, v. 2, n. 4, p. 355-367. 
OECD (2013). Recent Developments in Rail Transportation Services. OECD ITF Round Tables, DAF/COMP. Disponível em: <http://www.oecd.org/daf/competition/Railtransportation-Services-2013.pdf>.

OJIMA, A. L. R. O.; COMITRE, V. (2014). O Setor Ferroviário sob a perspectiva da Economia dos Custos de Transação: a experiência do transporte de algumas commodities do agronegócio. XLVI Congresso da Sociedade Brasileira de Economia, Administração e Sociologia Rural. Rio Branco: Sociedade Brasileira de Economia, Administração e Sociologia Rural.

OLIVEIRA, E. (2014). Vale conclui venda de fatia da VLI à Mitsui e ao FI-FGTS, 15 abril 2014. Disponível em: <http://economia.estadao.com.br/noticias/negocios,vale-conclui-vendade-fatia-da-vli-a-mitsui-e-ao-fi-fgts,182083e> .

PERRY, M. K. (1989). Vertical integration: Determinants and effects. In: SCHMALENSEE, R.; WILLIG, R. Handbook of Industrial Organization. 1st edition. ed. Elsevier, v. 1. p. 183-255.

PINDYCK, R. S.; RUBINFELD, D. L. (2009). Microeconomics. 7th Edition. ed. New Jersey: Pearson Prentice Hall.

PINHEIRO, A. C. (2014). A nova reforma regulatória do setor ferroviário. In: Gargalos e soluções na infraestrutura de transportes, por Armando C. PINHEIRO e Cláudio FRISCHTAK, 348 p. Rio de Janeiro: Editora FGV.

PITTMAN, R. A. (2003). Note on Non-Discriminatory Access to Railroad. US Department of Justice, Antitrust Division. Disponível em: <http://128.118.178.162/eps/io/papers/0303/0303004.pdf>.

PORTER, M. E. (1979). How Competitive Forces Shape Strategy. Harvard Business Review, março-abril 1979. Disponível em: <http://prolog.univie.ac.at/teaching/LVAs/KFKLM/WS07/Porter.pdf>

POSNER, R. A. (1969). Natural Monopoly and its Regulation, v. 21, p. 548-643, fevereiro 1969.

POSSAS, M.; FAGUNDES, J.; PONDRÉ, J. L. (1998). Defesa da Concorrência e Regulação de Setores de Infraestrutura em Transição. UFRJ. Disponível em: <http://www.institutounipac.com.br/aulas/2012/1/UBAGR07N1/001486/000/defesa_da_conc orrencia\%2520e_regulacao_de_setores_de_infra_estrutura_em_transicao.pdf $>$.

RESENDE, M. (1997). Regimes Regulatórios: Possibilidades e Limites. Pesquisa e Planejamento Econômico, Rio de Janeiro, 27, n. 3, dezembro 1997. p. 641-664.

RIBEIRO, M. P. (2011). Concessões e PPPs: Melhores Práticas em Licitações e Contratos. Editora Atlas. p. 232.

RUS, G. D.; CAMPOS, J. (2006). Los fundamentos económicos de la política de transporte europea: un análisis crítico. In: RUS, G. D. La política de transporte europea: El papel del análisis económico. Bilbao: Fundación BBVA. p. 21-52. 
SAINTIVE, M. B.; CHACUR, R. S. (2006). A Regulação Tarifária e o Comportamento dos Preços Administrados. Ministério da Fazenda.

SALGADO, L. H. (2003). Agências regulatórias na experiência brasileira: um panorama do atual desenho institucional. Rio de Janeiro. Disponível em: <http://repositorio.ipea.gov.br/bitstream/11058/2859/1/TD_941.pdf>.

SALGADO, L. H.; MOTTA, R. S. (2005). Marcos regulatórios no Brasil: o que foi feito e o que falta fazer. Rio de Janeiro: IPEA. 404 p. Disponível em:

<http://www.ipea.gov.br/agencia/images/stories/PDFs/marcosregulatoriosnobrasil.pdf>.

SILVA, M. M. F. (1954). Geografia das Estradas de Ferro Brasileiras. In: IBGE I

Centenário das Ferrovias Brasileiras. Rio de Janeiro. p. 1-85. Disponível em:

$<$ http://biblioteca.ibge.gov.br/visualizacao/monografias/GEBIS\%20-

$\% 20 \mathrm{RJ} /$ centenarioferrovias1954.pdf $>$.

SIMON, H. A. (1982). Models of Bounded Rationality: Empirically grounded economic reason. MIT Press, v. 3.

STADUTO, J. A. R.; DA ROCHA JR, W. F.; DE FREITAS, C. A. (2003). Relendo Chandler, Williamson e North para entender o processo de formação das estradas de ferro no Brasil. Revista Análise Econômica, Porto Alegre, 21, n. 40, setembro 2003. p. 207-225. Disponível em: <http://seer.ufrgs.br/index.php/AnaliseEconomica/article/view/10741/6355>.

STERN, J. (2003). What the Littlechild report actually said. Regulation Initiative Working Paper No. 55, London Business School \& NERA, London.

TRIBUNAL DE CONTAS DA UNIÃO - TCU (1998). Acórdão TCU no 621, de 16/09/1998.

THE ECONOMIST (2008). Idea: Economies of Scale and Scope. 20 de outubro de 2008.

The Economist. Disponível em: 〈http://www.economist.com/node/12446567>

THE WORLD BANK (2014). Railway Cost Structures. Railway Reform: Toolkit for Improving Rail Sector Performance. Disponível em:

$<$ http://www.ppiaf.org/sites/ppiaf.org/files/documents/toolkits/railways_toolkit/ch2_1_2.html $>$

UNICA (2014). UNICADATA: Exportação e Importação: Relatórios Mensais: Açúcar: Civil. maio de 2014. Websiste da ÚNICA. Disponível em:

<http://www.unicadata.com.br/listagem.php?idMn=73\&ano=civil>

USDA (2013). Agricultural Transportation: Transportation of U.S. Grains: A Modal Share Analysis. 15 de maio de 2013. USDA: Agricultural Marketing Service Website.

Disponível em: < http://www.ams.usda.gov>

USDA (2014). Soybean Transportation Guide: Brazil 2013. USDA, Agricultural Marketing Service. Junho de 2014.

VAN DE VELDE, D.; NASH, C.; SMITH, A.; MIZUTANI, F.; URANISHI, S.; LIJESEN, M., et al. (2012). EVES-Rail: Economic Effects of Vertical Separation in the Railway 
Sector. Full Technical Report to Community of European Railway and Infrastructure Companies, Amsterdam.

VIERTH, I. (2011). 15 years deregulated rail freight market-lessons from Sweden. European Transport Conference 2011, 20 p. Glasgow.

WILLIAMSON, O. E. (1985). The Economic Institutions of Capitalism. The Free Press.

WILLIAMSON, O. E. (1989). Transaction cost economics. Handbook of industrial organization, 1, p. 135-182.

ZAMIN (2014). Projects: Amapá. Website do Grupo Zamin. Disponível em: <http://www.zamin.com/index.php/en/operations/amapa>. 